








\section{LAVAS AND SOILS}

OF THE

HAWAIIAN ISLANDS.

Investigations of the

Hawailan Experiment Station and Laboratories.

WALTER MAXWELL

DIRECTOR AND CHIEF CHEMIST.

HONOLULU :

HAWAIIAN GAZETTE COMPANY. I 898 . 

Consulate feneral of the United Slates.

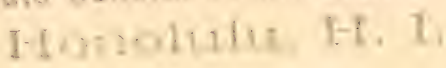

of 1 in you 


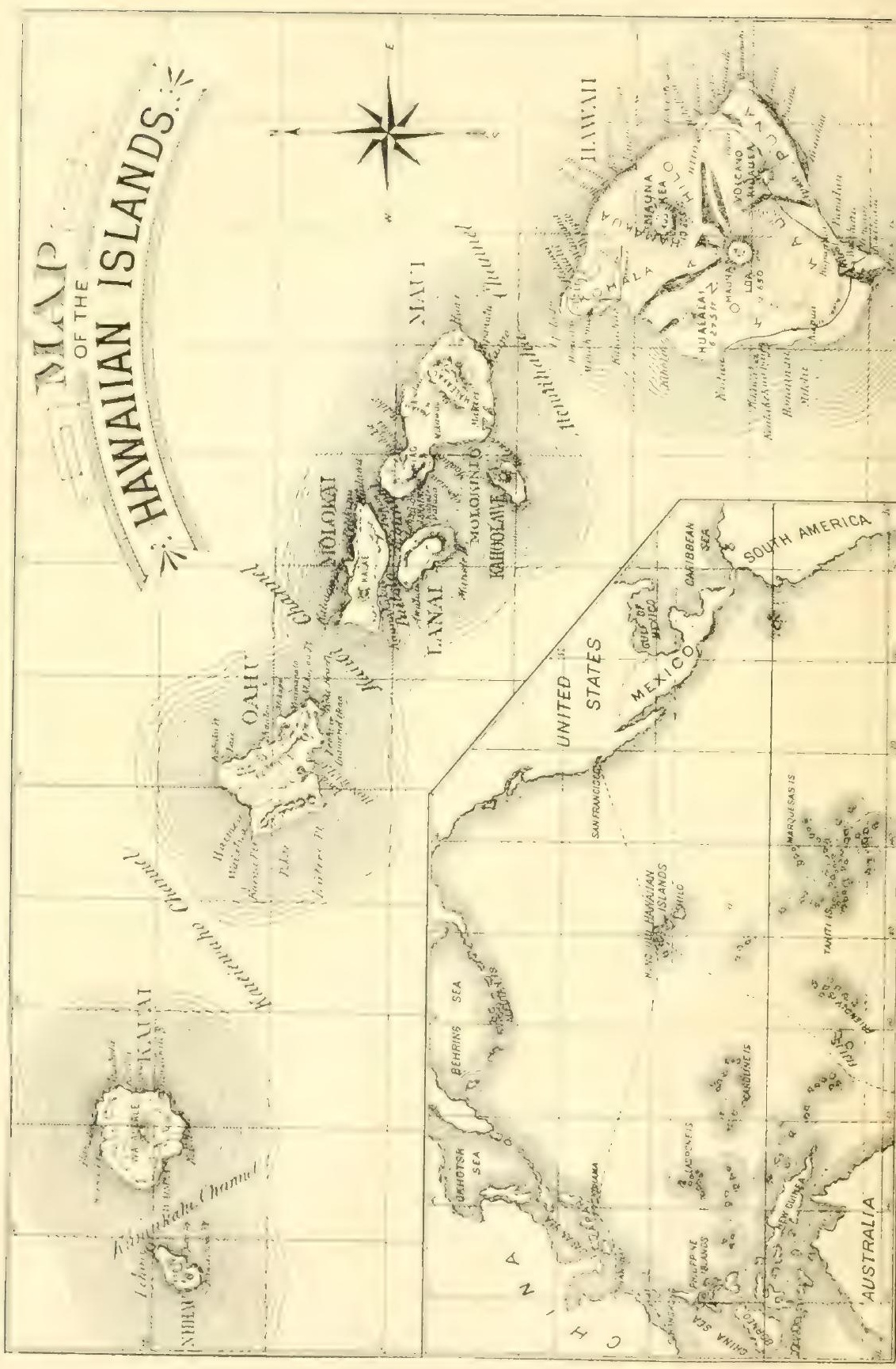




\title{
LAVAS AND SOILS
}

OF THE

\section{HAWAIIAN ISLANDS.}

\author{
INVESTIGATIONS \\ OF THE \\ HAWAIIAN EXPERIMENT STATION \\ AND \\ LABORATORIES
}

BY

WALTER MAXWELL, - - - Director and Chief Chemist

Assisted by

J. T. CRAWLEY - - - - - First Assistant Chemist,

C. F. ECKART - - - - - Second Assistant Chemist

And

E. G. CLARKE, - - - - - Field Assistant.

1. Origin and Nature of Hawaiian Soils.

2. Availability and Loss of the Elements of Plant Food in Hawaiian Soils.

Published by Order of the Hawailan Sugar Planters' Association, 1808 . 
in III 
Trustees and Hembers of the Hawaiian Sugar Planters' Association.

Gentlemen:-I hereby submit a report, setting forth the results of investigations of Hawaiian soils.

The scope of the investigations, involving a careful study of the lavas from which the soils have been formerl, may appear, at first sight, to extend beyoud the recuirements of the subject: An examination of the report in detail will, I believe, make it very clear that it would not have been possible to arrive at an understanding of the great differences in the nature of the soils, and in their economic ralues, without a preceding study of the lavas such as was undertaken.

The discussion in detail of the chemical processes, and of the laboratory methods, is required in order that other scientific men may follow the mode of the investigations, and judge of the value of the results.

In laying the plan of the investigations, and in the study and adoption of methods for its execution, I have endearored, before all else, to observe and be guided by Nature. For this reason, repeated visits have been made to each plantation and district on the four islands: soils bave been examined in place, with the lavas from which they were derived, and in careful connection with the local climatic conditions and environment.

In the efforts to establish a reliable mode of estimat. ing the state of availability of the essential elements of plant food in the soils, I have tried to find out the processes, and the results of the processes, that operate in the field; and then to bring the methods and procedure of the laboratory into harmony with these. The results 
will be fomm to amply justify and lewall the combers that has been followed.

In carying out such a plan of investigation as $I$ have described, assistance in each part of the work was a necessity. Therefore I wish-First, to acknowledge the aid fumished by the gentlemen on plantations in obtaining soils, and in recording the climatic and other local conditions.

Further, without the co-operation of the gentlemen in the laboratory the execution of the work had not been jossible. To First Assistant crawley I have been gureatly indebted, and not only for the many extremely delicate analytical results that he has furnished, but also for raluable critical observations in the adjustment of the methods of the laboratory, in order to compare with the processes in the field, upon which the laboratory procedme was based. Also, in the analysis of lavas and soils, serond Assistant Edkat has mendered indispensable ats sistance.

In the outdoor part of the experiments, which were conducted in the experiment station field, I have been ably and faithfully assisted, in the camying out in detail of tests and observations by Field Assistant Clarke. In fact, it is not possible to say too much of the assistance received from these several sources.

With these and continued inrestigations of the soils as a basis, the experiment station is now proceeding with a broad plan, embracing the Relations of Soils to Crops.

\section{Watter MLAXWelt,}

Director and Chief Chemist.

Honolulu, H. I., 1898. 


\section{DEFINITIONS.}

Symbol.

Name.

Si $\mathrm{O}_{2} \ldots \ldots \ldots \ldots \ldots$. Silica.

Ti $0 . \ldots \ldots \ldots \ldots \ldots \ldots \ldots$ Titanic Ar.

$\mathrm{P}_{2} \mathrm{O}_{5} \ldots \ldots \ldots \ldots \ldots$. Phosphoric Acid.

S $\mathrm{O}_{3} \ldots \ldots \ldots \ldots \ldots \ldots$. Sulphuric Acid.

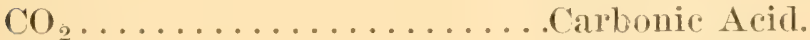

H Cl.................. Hydrochloric Acid.

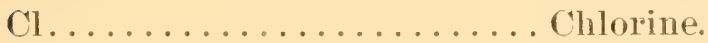

Fe $0 \ldots \ldots \ldots \ldots \ldots \ldots \ldots$ Femons Oxide.

$\mathrm{Fe}_{2} \mathrm{O}_{3} \ldots \ldots \ldots \ldots \ldots \ldots$ Ferric Oxide.

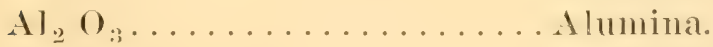

$\mathrm{Fe}_{2} \mathrm{Al}_{2} \mathrm{O}_{6} \ldots \ldots \ldots \ldots \ldots$. Tron and Alumina.

Ca $0 \ldots \ldots \ldots \ldots$. . . . . . . .

Мg O .............. Magnesia.

$\mathrm{Mn}_{3} \mathrm{O}_{4} \ldots \ldots \ldots \ldots \ldots \ldots$ Manganese Oxide.

$\mathrm{K}_{2} \mathrm{O} \ldots \ldots \ldots \ldots$ Potash.

$\mathrm{Na}_{2} \mathrm{O} \ldots \ldots \ldots \ldots \ldots$ Soda.

N. . . . . . . . . . . . . Nitrogen. 



\title{
ORIGIN AND NATURE
}

OF

\author{
HAWAIIAN SOILS.
}

The mineral constituents of all soils are furnished by rocks or lavas, as a result of disintegration. This truth, in the examination of particular soils, causes us, in the first place, to give precise attention to the rocks from which these soils have been derived.

\section{HAWAIIAN LAVAS AND ROCKS.}

The Islauds of Hawaii are of voleanic origin, therefore the rock materials composing the mountains and elevations above the sea are igneous in character. Professor Dana says, "The Hawaiian Island group is an example of a line of great volcanic mountains. Fifteen volcanoes of the first class have existed, and have been in brilliant action along the line."

Petrographically, the lavas and rocks composing the great mass of the structure of these Islands are basaltio lavas. Recurring to the definitions of Dana, "these basaltic lavas belong to the same class, although they vary widely:-in color, from dark to light gray; in structure, from compact to highly vesicular, and from those of uniform grain to those which are prominently por- 
phyritic, with chrysolite or feldspar." In his mineralogical examinations, which are confirmed by chemical analyses, Dana speaks of only one "remarkable feldspathic andesyte of a totally different rock from any other obtained from the Islands," which did not "con form to that of normal basalt."

In the following definite examinations of Hawaian lavas, their chemical composition was taken as represent. ing more exactly the standpoint from which, in the plan of our investiqations, these lavas, as the materials furnishing soils, must be considered. In order to obtain a widely representative view of their chemical composition, trpical samples of great lava masses nere selected personally by the writer, in the comse of repeated in. spections, from districts on Hawaii, Maui, Kauai, and Oahn, and the arerage composition of these lavas is given in the following table, and in comparison with the analy. ses of American basalts, for which we are indebted to Professor Clarke, of the U. S. Geological Survey. Individual analyses of Hawaiian lavas will be given later:-

\begin{tabular}{|c|c|c|c|c|c|c|c|c|}
\hline Materials. & Analy'ses & $\mathrm{SiO}_{2}$ & $\mathrm{Al}_{2} \mathrm{O}_{3}$ & $\mathrm{Fe}_{2} \mathrm{O}_{3}$ & $\mathrm{CaO}$ & $\mathrm{Mg} \quad \mathrm{O}$ & $\mathrm{Na}_{2} \mathrm{O}$ & $\mathrm{K}_{2} \mathrm{O}$ \\
\hline & & $\begin{array}{l}\text { Per } \\
\text { cent. }\end{array}$ & $\begin{array}{c}\text { Per } \\
\text { cent }\end{array}$ & $\begin{array}{l}\text { Per } \\
\text { cent. }\end{array}$ & $\begin{array}{c}\text { Per } \\
\text { cent. }\end{array}$ & $\begin{array}{l}\text { Per } \\
\text { cent. }\end{array}$ & $\begin{array}{c}\text { Per } \\
\text { cent. }\end{array}$ & $\begin{array}{l}\text { Per } \\
\text { cent. }\end{array}$ \\
\hline Hawaiian Lavas.... & 18 & 47.90 & 1823 & 1336 & 8.99 & 6.05 & 5.20 & 1. 50 \\
\hline American Basalts.. & 20 & 49.15 & 15.66 & 950 & 8.29 & 7.90 & 2.81 & 1.90 \\
\hline
\end{tabular}

The chemical composition of Hawaiian lavas conforms to the normal constitution of basalts, and is in general agreement with that of basalts selected from igneous rock masses found in widely separated regions in America. 


\section{DISINTEGRATION OF LAVAS AND ROCKS.}

The disintegration of rocks, or the action by which these become resolved into the mineral constituents of soils, is usually defined under the expression of "weather. ing," which is understood to include all the operations of climatic influences-heat, cold, drought, moistureunder which solid rocks and stones are reduced to palpable earth. That single term is quite inadequate to comprehend the processes by which the disintegration of rocks is brought about, and in the matter of Hawaiian lavas it may be possible to show that, essentially prior to the áction of simple wcathering, there were other definite physical and chemical causes, whose action covered wide areas of distribution, and which were not only primary agencies in the decomposition of these lavas, but factors determining very specifically the kinds of soils they were to form.

We were led into the investigation of causes of rock disintegration, that have operated prior to the contact of weathering, by reason of evident differences in the soils of given areas, which had been derived from the same lava flows, and essentially subjected to the same climatic influences.

One of the effective agents of rock disintegration is oxygen. It acts directly as a free element; more potently through the medium of water; still more effectively in and as steam. When lavas are ejected, or flow, during periods of crater activity the action may be caused, and is frequently accompanied, by the inlet of water into the crater, which is turned to steam, and the steam becomes enveloped and held by the lava. Lavas, in which steam has been enclosed, are more or less marked by a resicular 
structure, the resicles or holes being left in the lava where the steam has disappeared on cooling. The steam, however, has permeated the cold lava, and is found to have entered partly into combination with its consti. tnents. The following table gives the average partial composition of Hawaiian lavas, examined by us, that are distinguished by different amounts of moisture and combined water; one class being close and compact in struc. ture, and the other from less to more vesicular; yet all these were sound lavas in appearance, those containing the most water being more brittle, and their constituents minerals-angite, chrysolite, etc-in a more mature form of erystallization.

\begin{tabular}{|c|c|c|c|c|c|c|}
\hline Lavas. & $\begin{array}{l}\text { Mois- } \\
\text { ture. }\end{array}$ & $\begin{array}{l}\text { Com- } \\
\text { bined } \\
\text { Water. }\end{array}$ & $\mathrm{SiO}_{2}$ & $\begin{array}{c}\mathrm{Fe} O \\
\mathrm{Fe}_{2}^{+} \mathrm{O}_{3}\end{array}$ & $\mathrm{Al}_{2} \mathrm{O}_{3}$ & $\mathrm{CaO}$ \\
\hline & $\begin{array}{l}\text { Per } \\
\text { eent. }\end{array}$ & $\begin{array}{l}\text { Per } \\
\text { cent }\end{array}$ & $\begin{array}{l}\text { Per } \\
\text { cent. }\end{array}$ & $\begin{array}{c}\text { Per } \\
\text { cent. }\end{array}$ & $\begin{array}{l}\text { Per } \\
\text { cent. }\end{array}$ & $\begin{array}{l}\text { Per } \\
\text { cent. }\end{array}$ \\
\hline Non-Hydrons Lavas. & 0.40 & 0.14 & 48.10 & 1275 & 20.70 & 9.24 \\
\hline Hydrous Lavas. & 0.90 & 2.20 & 4520 & 14.01 & 18.20 & 8.23 \\
\hline
\end{tabular}

As the taking up of oxygen and water are the first steps in the decomposition of rocks, it is indicated by the bot tom line of analyses that these hydrous lavas, notwithstanding their brittle and sound appearance, have already passed the initial stage in disintegration.

A second and most effective class of agents which operate in the disintegration of lacas are mineral acids, which are a result of the primary oxydizing action of steam upon the lavas of high temperature, lying at depths from the surface.

When the writer, in the course of a second visit of inspection to the Island of Hawaii in the spring of 1896 , first approached the location of the active crater of 



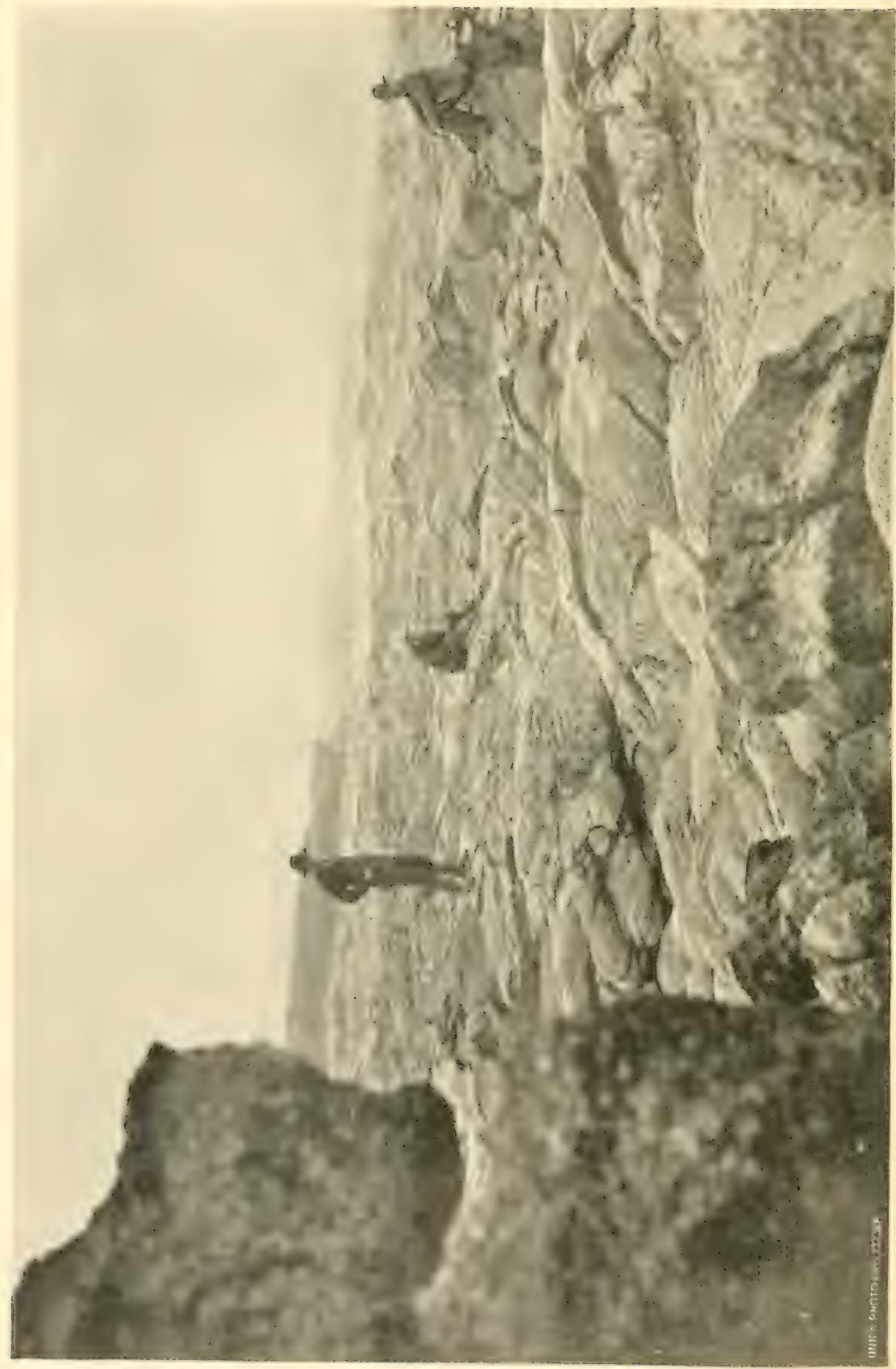

है 
Kilanca, a new order of suggestions occurred to him, which, upon a closer survey of the conditions and phenomena presented by the actual crater and its sur. roundings, developed into definite thoughts, and into a series of analytical examinations, which rere to bear upon the attempt to explain the causes of difference in Hawaiian soils already spoken of.

The crater of Kilauea, according to data furnished to us by Professor Alexander, Surveror-qeneral, is 3972 feet above the sea. Within the walls of the crater is enclosed air area of $4.14 \mathrm{sq}$. miles, or 2650 acres. The present area, or lake of burning liquid activity, may not cover more than fifty acres, and forms a crater within the crater. The total area of the vast crater, howerer, is covered by activity of volcanic phenomena. Viewed in the morn. ing before sunrise, when the air temperature is low, a large part of the crater floor is more or less concealed by condensing steam, which is issuing from fissures and fractures in the lava, that were produced on partial cooling. Some preliminary observations showed us that at some places of escape the steam gare no reaction with litmus paper; in other places a mildly acid reaction was found; whilst over other well-defined areas the issuing steam was intensely acid and hot. It was further noticed that, orer the steaming areas, deposits were laid of dis. solved materials brought up through fissures; and отеr areas of intense action of acid steam the general surface of the lavas was undergoing acute change.

During the first visit to the crater, typical samples of sound lava, of decomposing lava, and of several decom. position products, were taken, and brought to the laboratory for examination. We made a second risit a ferl months later, being prepared to make more precise ob- 
servations mpon the nature of the active agents in lava decomposition actually operating at this time, and to locale and ident ify some of the poodurts of disintegration.

'The temperature of the steam leaving the fissures showed every degree from the lowest up to the last point of condensation. There are also fissures from which, doubtless, moisture is escaping, but the temperature is too high for condensation at the lava surface. The writer found no difficulty in lighting a cigar on the walls of the fissures one foot from the surface, whilst after sundown, the crevasses near to the actual lake, at a depth of five to ten feet, become red and luminous with lieat.

Actual tests of the character of the steam issuing from the lavas showed localities where the steam was strictly 110utlal: others wherea slight aldolity Was ateting, and the areas, where we have already said that the escaping steam was intensely acid and hot, the water, which we obtained by use of a simple arrangement for condens. ing the steam, was found to contain $4.92 \%$ of acid, which was exclusively sulphuric, not a trace of chlorine being given, indicating that the crater is closed against an imoad of the sea, which is but some twenty miles distant.

It the time of examining the temperature and character of the steam, samples were taken of normal lava, of lava being acted upon by the highly acid steam, and of materials resulting from the steam action. In the partial analyses in the following table:

A-is a sample of lava froth, or scum, which rests to a depth of six inches upon the more solid lava. This lava is normal, and not acted mpon by steam, and is a lark wray in color. 
B - is a sample of the same lava as A, and thus of the same lava flow, but is being acted upon by sulphurous steam. The color is changed from the normal dark gray to variations between yellow and vivid red, due to action of steam on the iron, which has been notably altered.

$\mathrm{C}$-is a sample of material taken from the lips of slight. ly acid fissures, whence the steam is constantly issuing. This material is, in part, deposits of matters bronght up by the steam, and partly the lava in place which has nudergone change, and become mixed with the deposit.

\begin{tabular}{|c|c|c|c|}
\hline Elements. & A & B & C! \\
\hline 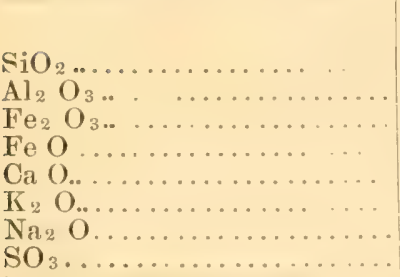 & $\begin{array}{l}\text { Per cent. } \\
49.010 \\
16.129 \\
7.291 \\
10.100 \\
10.660 \\
0.647 \\
4.201 \\
0.240\end{array}$ & $\begin{array}{l}\text { Per cent. } \\
55.490 \\
16.000 \\
5.650 \\
6.830 \\
7.957 \\
0.686 \\
4.403 \\
0.601\end{array}$ & $\begin{array}{l}\text { Per cent. } \\
62.450 \\
9.220 \\
5.010 \\
3018 \\
4.190 \\
0.280 \\
0.300 \\
\text {. }\end{array}$ \\
\hline
\end{tabular}

These analyses indicate, as we shall see later, only in a small measure the decomposing action of sulphurous steam, whereby the products of disintegration do not compare with the decomposition products of simple woathering. The action of the acid steam, which is denoted by the analysis of material $B$, is operating orer a number of separate areas which in the aggregate make up about 150 acres, or one-fifteenth of the whole crater. These separate areas are distinguishable from the great. er part of the crater surface at a great distance. The lava over the most part of the crater floor is still dark in color, or changing slowly to a lighter gray, or faintly chocolate shade, whilst the areas affected by the intense 
action of the acid steam are rapidly changed to surfaces of striking light reds and yellows.

Much more acute, advanced, and far-reaching exam. ples of lava disintegration muler the action of physical and rhemical agents, than we hatre lescribed as going on over the crater floor, are proceeding upon areas lying at present, outside the crater, and situated upon the boumdaries of its opposite ends, and some two to three miles apart. Those areas are known as the "Kilanea sulphur banks," which term aptly expresses the nature of the agency in operation. The sulphur banks near by the Volcana hotel, which is located on the eminence over. looking the crater, are those best known; but during the writer's last visit to the crater, when the whole areas were traversed and re-traversed and examined, the area of intense disintegrating action at the opposite end of the crater was found to be on a larger scale, and many of the products of the decomposition better separated and defined. But as the observations made during the pre. vious visit, and the samples of lava, and of decomposition products, taken for analytical examination, were confined more chiefly to the area in the locality of the Tolcano House, observations made during the later visit were also largely devoted to that area.

The area near to the Volcano House covers some fifty acres, and may be described as a grand solfuturu, over whose surface are found numberless fumaroles, which are holes of sizes varying from one to twenty square feet, connected by fissures with the hot interior. Many of these holes and fissures go down unknown feet in direct. depth, and care is necessary when moving near to them. At the time of our second visit, a horse belonging to the hotel slipped into one of those fissmes, and was never 


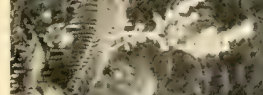



seen, and no sound from the animal heard again. Amongst other general phenomena which impress the observer-it is likely that there is no other spot upon the surface of the planet at this time which can so acutely appeal to persons inclined to think upon material phenomena, or even upon the origin of certain expiring philosophies, as the one of which we are speaking - is the behaviour of vegetation. Over a large part of this solfatara grasses and weeds are existing; and by the sides of the fumaroles, bushes, and even trees, have reached a reasonable size. We distinctly noted the roots of the Ohia-Lehna, and of certain coarse ferns, grown out on the sides of the fumaroles, up which steam, laden heavily with sulphurous acid, was escaping, and whose leaves were white with deposits of sulphur, and yet the Ohia and ferns are growing and strong. But these organisms, in their growth, are assimilating nitrogen: Is this un-nitrified nitrogen? Or are micro-organisms existing in these intensely acid conditions, and preparing un-nitrified nitrogen for those plants? Here are phenomena which perhaps have not been known of when certain existing theories on plant nutrition were fom ded?

In our examination of the work of lava disintegration, which is going on at this moment, and upon a scale so large and grand that it must almost lie outside our conception and range were we limited to the experience of chemical processes in laboratories, we obtained samples of sound lavas; of these lavas in varying stages of decom. position; of the agent under whose action the disintegration is taking place; and of certain of the products into which the solid laval is being resolved. And in speaking of these samples, it may be said that they do not represent small amounts, but bulks of such vast proportion 
that their ntilization has been nucler consideration for commercial purposes. Over the whole area, sometimes upon the top, in other places a fer inches beneath the surfaces, and again upon the sicles of the fumaroles, masses of pure sulphur are crystallized out. Then, there are alum deposits; heaps of extracted lime, lying in the form of almost pure grpsum, and beds of so-called red and yellow ochres, wherein we have to search for the iron and silica.

At this time, we have before us the most extraordinarily illustrative specimens, showing the comse of disintegration by which the solid lava is resolved into the products named. 'L'hese were obtained by working away several feet of the outer edge of the decomposing lava and securing blocks in place, which had never been expos. ed to the air, and upon which the sulphurous steam was constantly acting. At the time of taking the specimens the lava bloclis were so hot that the hand could not touch them, and the steam, on passing into the air, was $90^{\circ} \mathrm{C}$ (194 Fahrenheit), but down in the interior of the lava, in fissures, no steam was visible, showing that the heat was above $100^{\circ} \mathrm{C}$. The watel collected by condensing this steam at a point of exit contained $5 \%$ of sulphuric acid, but no chlorine. 'Two of these larger specimen blocks of lava, in states of decomposition, are partially studded with mature crystals of sulphur. Where the acid steam has eaten out cavities, these are partly filled with clustered crystals of gypsum, and some alums, each of these being very definitely separated. Over the surface, and within the blocks is seen the iron gathering to gether in pockets of red ochre, and the siliea separating in distinct masses of a so-called yellow ochre, and in places the silica is deposited almost pure. With most 
of the numerous specimens collected by us the separation and crystallization have gone on and matured since they were brought to the laboratory, and we hare before us, not only exact, but very beautiful examples of the disin. tegration of the lava, and the formation of the productio that result from their decomposition.

The action of steam in the disintegration of igneous rocks has been remarked upon by several observers. Darwin, in speaking of steam action upon trachytic rocks at Telceira, in the Azores, says, "the steam is emitted from several fissures: it is scentless, soon blackens iron, and is of too high a temperature for the hand to bear." The steam spoken of by Darwin, which he says was "scentless," differs from the acid steam that we have described. That the steam "blackeus iron" is suggestive that some acid was present; and as Darwin did not make any analytical examinations, either of the steam $01^{\circ}$ the decomposition products, we are inclined to think that he was dealing with phenomena resembling these that we are describing. Moreover, Darwin says "the manner" in which the solid trachyte is changed on the borders of these orifices is curious: first, the base becomes earthy, with red freckles, evidently due to the oxydation of particles of iron; then it becomes soft. After the mass is converted into clay, the oxide of iron seems to be removed from some parts, which are left perfectly white, whilst in other neighboring parts, which are of the brightest red color, it seems to be deposited in greater quantity. The inhabitants use these substances for white washing." We are, from these products that Darwin describes, quite impressed that he was dealing with a corresponding condition of things to what we have observed at the Kilauea crater; yet we cannot say more, 
since the great scientist did not note the presence of definite decomposition products, and does not furnish any analytical data bearing upon phenomena, which he says "are still obseure." Darwin remarks that these things "hatre beren observest in othere plateses, in the Italian voleanic islands, and by Spallanzani, Dolomien, and others," which statement accentuates our persuasion that in speaking of phenomena found at Kilauea we are dealing with matter's that have had a more or less nniversal concern in the history of rock disintegration and soil formation on our globe.

We shall now give a small series of analyses of decom. position products of lava collected by us at Kilauea. 'To economize space these are given in a table.

A-is a sample of almost pure gypsum which is found ristributed in enormous quantities.

B-was taken from the "alum deposit," and is a mix. ture of sulphates of the alkalies, iron and alumina, with the excess of sulphur and sulphuric acid.

C-is a portion of the so-called "red ochre" which is foumd in large masses and layers, and more or less definitely separated from the other products.

D-is composed mainly of silica which has been releas. ed by the action of the sulphuric acid in the steam from the lava bases. It is yellow on drying, and becomes pink on glowing.

$\mathrm{E}$ is a material still showing the lava form, but exhibits

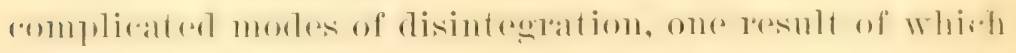
is that the silica increases to a falling ratio of the other elements. 
COMPOSTTION OF THE PRODUCTS OF DISINTEGRATION BEING FORMED FHOM 'THE LATA'S AT THE KILAUEA CRATER.

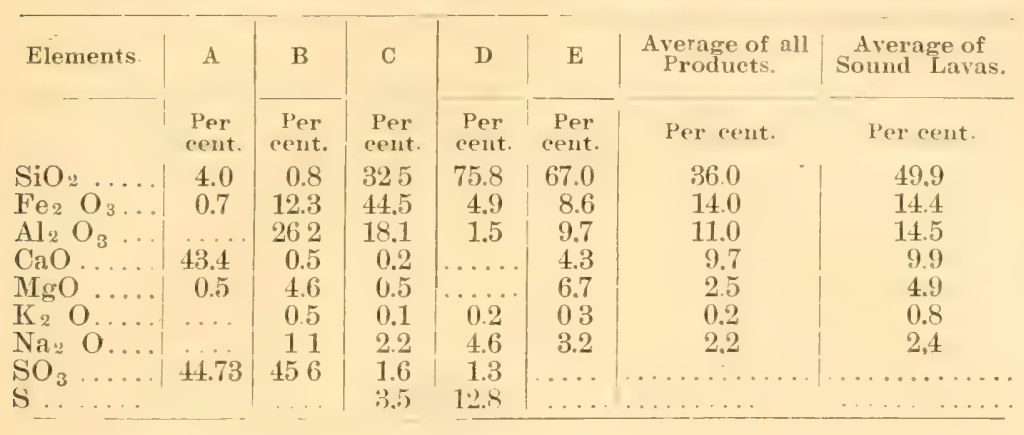

The analyses are only partially complete. The water is not given on account of the presence of sulphur and other rolatile bodies.

The table of data indicates the processes that are actually operating, and given products into which the lavas are being resolved by modes of disintegration that are visible to-day in the larogest natural laboratory upon the globe. These data have for us a profound significance and value, aiding in the general study of the processes by which lavas have been resolved into the compounds that form other kinds of rocks, or into the materials of which our soils are composed, phenomena to which we shall recur at a later time.

The column containing the "average of all products," which is compared with the composition of the "average of sound lavas," is not to be taken to mean that we have found, and attempted to put together again, the materials of which the lava was composed: This would be merely toying with a matter of the first magnitude, and in its nature, impossible; since much of the more soluble products has been borne away in solution by the rains. The data in the column imply that disintegration 
products have been found, the average composition of which is compared with that of the sound lavas.

The presence of sulphuric acid and sulphur leares no doubt as to the agent by which the disintegration has been chiefly caused; and the behaviour of the alkalies, especially soda, suggest matter's to which we shall recur when speaking more definitely of soils.

In connection with those examinations of the lava, lava decomposition products, and of the agents by which the disintegration is being caused, an experiment was made in our laboratory showing the action of acid steam on lava. Lava, of a known chemical composition, was broken into pieces of the size of a large bean, and put in. to a glass tube. This tube was connected with an Erlenmeyer flask containing a five per cent. solution of sulphuric acid, which is the acid strength of the con densed steam operating at the crater where our samples of the products of decomposition were taken. The other end of the tube was connected with a condenser, by which means the acirl solution rose as steam through the lava in the tube, and returned to the flask. Exactly 52.9 grams of lava were put into the tube, and the acid steam acted upon it for 120 days. After this period of action, 1.221 grams of solid matter was found in the solution, the composition of which was as follows, after deducting the amounts of soda and silica dissolved out of the glass of the Erlenmeyer flask.

$$
\begin{aligned}
& \text { Si } \mathrm{O}_{2}=16.00 \text { per cent. } \\
& \mathrm{Fe}_{2} \mathrm{O}_{3}=1.70 \text { per cent. } \\
& \mathrm{Al}_{2} \mathrm{O}=4.56 \text { per cent. } \\
& \mathrm{Ca} \mathrm{O}=6.53 \text { per cent. } \\
& \mathrm{K}_{2} \mathrm{O}=5.58 \text { per cent. } \\
& \mathrm{Na}_{2} \mathrm{O}=5.00 \text { per cent. } \\
& \mathrm{SO}_{3} \text {, etc. }=60.73 \text { per cent. }
\end{aligned}
$$


These data are highly instructive in indicating the mode in which the disintegration may be proceeding in nature. They show the amount of silica that is released by the action of the sulphuric acid on the bases in the lava. Also it is seen how the "alum deposits" are formed by the separation of the alumina and alkalies, as sulphates, from the lava. The removal of the lime ac. counts just as simply for the deposits of gypsum, whilst the iron is less affected, whirh suggests that those recom. position products of the lava that are extremely rich in iron are residual, rather than separation products, showing what is left of the original lava after the soluble silica, and the elements which form the alums and gyp. sum have been removed. There are other morles of disintegration that are not yet as well understood, and which result in the evident removal of the iron.

The time that has been given to the study of phenomena that are actually visible at the present time in the pro. cesses of disintegration operating at the Kilanea crater is for the purpose of determining, if possible, a connection between what is now going on at the volcano, and what may have taken place in other localities of past volcanic action, and the relation of these phases and re. sults of volcanic action to the marked differences in our soils. The questions that present themselves to us are the following:--Have the modes of lava-disintegration, that are going on to-day in the locality of the active crater, operated in past times, and in other parts of these islands? If so, how, and to what extent, have the soils derived from the lavas been affected by those intense physical and rhemical processes of rock disintegration? We shall now try to see what can be known along the line of these questions. 
Evidences of Chemieal Letion in the Disintegration of the Older Lates, and in the Formation of Soils.-The study of physical and chemical action as a factor in the disintegration of lavas, and in determining the character of soils, has, so far, been confined to the phenomena attending the decomposition of lavas seen to-day at the Kilanea crater. 'To ascertain whether these physical and chemical causes have operated on a grand scale, and over wide areas in the other volcanic regions we have to go out and examine the lavas and soils in the several parts of all the islands. In order to closely con. nect further investigation with the observations made at the active rolcano, we shall continue with the-

Istand OF HAWAI-This island, which is the largest in the group, comprises some 4,210 squate miles of sur. face. Its formation has resulted from the action of four glaud center's of eruption, or "craters of the first class," viz-Mama Loa, Mauna Kea, Hualalai, and the crater of the Kohala momntain system, whose location is in. definite. The present active crater of Kilanea cannot be included in this class, since it has not borne any similar part in the work of construction of the island.

From a point of elevation in the Kohala monntains, from which the writer marle these topographic observations, the system of grand craters is completely under riew: with Mamma Kea to the left, and Hualalai to the right, Mauna Loa closes up the view, at a distance of some sixty miles, to the south. From this point of elevation it is indicated how each of the four great mountains had an individual origin and growth, first coming into visible existence above the surface of the ocean, and hulding up by the malterial of sulsepurent aruptions, until the huge cones were raised respectively 13,675 feet; 
13,805 feet; 8,275 feet, and 5,505 feet above the level of the sea. These cones are at distances of some thirty miles the one from the next nearest one. The spaces between the cones, which were filled by the ocean during the opening history of the construction, now form the interior valleys, the ocean divisions not only having become closed up, but the spaces have been raised to grand plateaus, by the infilling of the great discharges from the crater cones, and lie at levels of some 3,000 feet above the sea. The filling in of the ocean spaces separating the four great mountains, and the forming of the valleys, were not wholly done by the discharges from the sum. mits of those great cones: This work was largely affected by side-flows or outbursts from the sides of the great mountains at different altitudes. Those "outbursts" became more or less continuous at the places of origin, and their locations are now marked by "craters of the secondary class," known frequently as "lateral cones," also as "tufa cones," which vary in. dimensions from small mounds, that are hardly longer distinguishable, to basin-formed craters enclosing areas of many acres. In the course of the ride across the Waimea plain, and from the vantage point on the slopes of the Kohala moun. tains, the writer became able to somewhat grasp the magnificent vastness of the operations that had gone to the building of the island! Not only had each of the four grand cones raised their burning heads out of the sea, filling space and air with clouds of steam and confusion, an idea of which was giren to us through the recitals of the "side flow" from Mauna Loa in 1868, when the stream of lava poured down into the sea, heating the water to more than the hand could bear, for more than a mile out in the ocean, and killing all living things 
within it that had not escaped to pelagic depths, but the distribution of lateral cones had added a still further rastuess to the operations, and an increased confusion, and probably splendour, to the scene! In the space of a day's ride we noted no less than eighty-nine of these lateral cones, and observed mounds covered by forest on the mountain slopes which suggested many more. Each one of those, in its day and measure, was a center of eruptive force. Lava, in some form, came from their throats, and fumes and steam escaped from fissures in the lays in their locations, leaving marks of their action in disintegration to which we must specially recur. This distribution of centers of eruptive action gives to the valleys dividing the great cones the true character of vast rolcanic plains, which afford the most impressive sight of its kind that the writer has ever beheld.

\section{PRTMARY EFFECTS OF CHEMICAT ACITON ON LAVAS.}

In the previous paragraphs the centers of eruptive action have been divided into "craters of the first class," and "lateral crater's," which we shall, for our present pur. pose, speak of as "tufa cones." The great crater's, during the periods of the most rigorous activity, have discharged the lavas which have built up the great rock masses forming the structure of these islands. T'hese rock masses indicate that the lavas were put forth at high temperatures; that they flowed smoothly, and cooled down into their present state withont much change in composition. There are indications, howerer, that the character of the discharges from the great craters was rarious: Instead of the high temperature, and free-flow. 


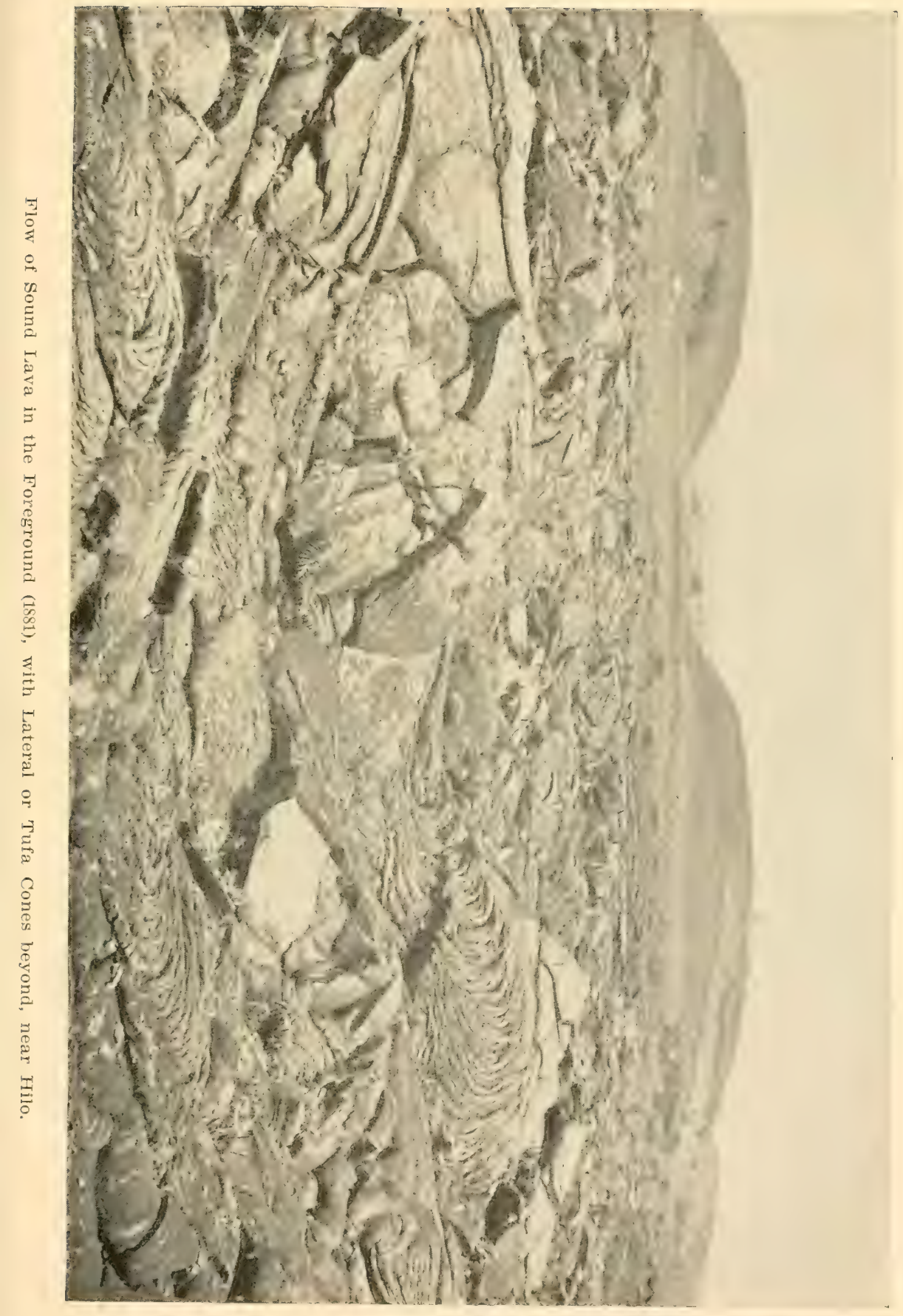



ing lavas, lavas of lower temperature, and puddled into a state of mud by excess of fresh water, were also dis. charged from the great craters. But these lavas do not necessarily differ in chemical composition from other solid laras. Again, the great craters, and apparently during the period when they were approaching extinction, have emitted materials-tufa, scoriae, asheswhich are more distinctly representative of the ejections of tufa cones.

The lateral or "tufa cones," in the earlier period of their activity, have also produced lavas, and built up their foundations with compact and solid materials, resembling the sound lavas emitted by the great craters. The material generally put forth, however, is of a different character, whose mass is made up of fragments of altered lava, in which are found enfolded lumps of less altered lava, which are easily distinguished from the brilliant red and yellow, or brown colors of the mass by their dark or blueish gray, which is the color of the normal basaltic lavas. This material in mass is known under the name of "tuff," or "tufa."

Dana defines tufa "as a rock not very hard, made from comminuted volcanic rock, more or less altered by the action of steam and vapors." He continues "the tufa made from those igneous rocks that contain iron-bearing minerals, such as basalt, is usually yellowish brown or red in color." Lyell defines tuf as "composed of small angular fragments of scoriae, and the dust of the same, produced by volcanic explosions." Teonhard also spealis of tufa and says "volcanoes produce, in addition to the solid lavas formed from the flowing laval strams, prouliar masses of ejected materials which are found in less or greater proportions around the borders and slopes of 
craters. 'These masses are composed of rolcanic ashes, saud, lapilli, bombs aud lava blocks."

Thufus, then are masses composed of fragments of the solid lavas of a given crater or volcanic region that have been severed and ejected by explosive eruptions, and which underwent a change of composition under the action of steam and acid rapors. Consequently there are several kinds of tufas, each depending upon the character of the solid lava, and as our lavas are strictly basalts, we have to deal exclusively with basaltir tufas.

From the agricultural standpoint, this matter of lavas, and of their origin and natme, is of the very greatest moment, and underlies any understanding of the soils derived from them. Areas upon certain of our planta. tions; are formed from solid, flowing lavas; whilst the soils in some rhole districts are the product of weathered tufas, and ate to be distinguished from other's as tufa soils. We therefore have had to con. sider the solid lavas, and more especially the tufas, mort minutely than the geologists have usually done, and par. ticularly their relative chemical compositions. If thr tufas, which are made up of fragments of solid lavas, in their course of ejection and later consolidation, have been acted upon by steam, or especially by acid vapors, a radical difference in their chemical composition would follow; and this would be permanent in its results, learling to the production of soils permanently different in characeter from soils derived from the solid, nomal latras. In order to carry out the examination of the lavas from which the several kinds of soils have been derived, the writer, in the course of visits to the districts of the fom islands, gave great cane to the selection of trpical specimens of lavas in the immerliate locality where samples 
of soil were taken. Many of the specimens of solid lavas, and of tufas, have been examined, and in the following tables are found strictly typical representatives of the two classes of rocks. The analyses, by reason of stress of work, are only partial, and are confined to observing the behaviour of the elements that would indicate the change of chemical composition on a grand scale in the passing over of the fragments, from solid lava masses, into tufa under the action of acid vapors. The first tables are given to solid lavas, dividing these into non-hydrous and hydrous lavas, and the last table to tufas.

\section{NON-HYDROUS SOLID LAVAS.}

\begin{tabular}{|c|c|c|c|c|c|c|}
\hline Moisture. & $\mid \begin{array}{c}\text { Combined } \\
\text { Water. }\end{array}$ & $\mathrm{Si} \mathrm{O}_{2}$ & $\mathrm{Fe} O$ & $\mathrm{Fe}_{2} \mathrm{O}_{3}$ & $\mathrm{Al}_{2} \mathrm{O}_{3}$ & $\mathrm{Ca} \mathrm{O}$ \\
\hline Per cent. & Per cent. & Per cent. & Per cent. & Per cent. & Per cent. & \\
\hline 0.73 & 0.28 & 48.18 & 8.40 & 4.42 & 18.02 & \\
\hline 0.04 & 0.09 & 52.51 & $9.9 \pm$ & 3.33 & 23.71 & \\
\hline 0.25 & 031 & 48.81 & 9.69 & 2.42 & 23.17 & 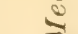 \\
\hline 0.49 & 0.00 & 52.89 & 6.51 & 3.64 & 17.80 & \\
\hline 0.63 & 0.08 & 47.85 & 7.66 & 4.20 & 28.62 & \\
\hline 0.36 & 0.07 & 44.45 & 8.39 & 6.23 & 20.32 & \\
\hline Teans 0.41 & 0.13 & 49.12 & 8.43 & 4.04 & 21.94 & $9.2 t$ \\
\hline
\end{tabular}

HYDROUS SOLID LAVAS.

\begin{tabular}{|c|c|c|c|c|c|c|}
\hline Moisture. & $\begin{array}{c}\text { Combined } \\
\text { Water. }\end{array}$ & $\mathrm{Si} \mathrm{O}_{2}$ & $\mathrm{Fe} O$ & $\mathrm{Fe}_{2} \mathrm{O}_{3}$ & $\mathrm{Al}_{2} \mathrm{O}_{3}$ & $\mathrm{CaO}$ \\
\hline $\begin{array}{c}\text { Per cent. } \\
0.33 \\
1.95 \\
1.05 \\
0.81 \\
0.10 \\
0.70\end{array}$ & $\begin{array}{c}\text { Per cent. } \\
0.90 \\
1.83 \\
2.53 \\
1.00 \\
4.27 \\
1.34\end{array}$ & $\begin{array}{c}\text { Per cent. } \\
42.19 \\
47.42 \\
44.85 \\
46.29 \\
40.95 \\
46.50\end{array}$ & $\begin{array}{c}\text { Per cent. } \\
6.71 \\
8.33 \\
9.91 \\
8.87 \\
11.17 \\
7.00\end{array}$ & $\begin{array}{c}\text { Per cent } \\
7.94 \\
4.18 \\
4.17 \\
3.82 \\
5.73 \\
6.87\end{array}$ & $\begin{array}{c}\text { Per cent. } \\
1207 \\
14.30 \\
20.44 \\
14.30 \\
19.74 \\
21.51\end{array}$ & $\underset{\Xi}{\stackrel{\Xi}{\Xi}}$ \\
\hline Means 0.82 & 1.96 & 44.66 & 8.66 & 5.62 & 17.60 & 8.23 \\
\hline
\end{tabular}


TUFAS.

\begin{tabular}{|c|c|c|c|c|c|c|}
\hline Moisture. & $\mid \begin{array}{c}\text { Combined } \\
\text { Watter. }\end{array}$ & $\mathrm{Si} \mathrm{O}_{2}$ & Fe O & $\mathrm{Fe}_{2} \mathrm{O}_{3}$ & $\mathrm{Al}_{2} \mathrm{O}_{3}$ & $\mathrm{CaO}$ \\
\hline $\begin{array}{c}\text { Per cent. } \\
3.97 \\
7.62 \\
10.63 \\
9.52 \\
7.25 \\
9.44 \\
7.16 \\
6.22\end{array}$ & $\begin{array}{c}\text { Per cent. } \\
12.98 \\
9.86 \\
11.15 \\
11.16 \\
11.23 \\
9.27 \\
11.37 \\
14.93\end{array}$ & $\begin{array}{c}\text { Per cent. } \\
15.92 \\
25.70 \\
23.72 \\
29.46 \\
31.69 \\
39.12 \\
2542 \\
21.52\end{array}$ & $\begin{array}{c}\text { Per cent, } \\
0.09 \\
1.23 \\
1.84 \\
2.93 \\
267 \\
0.79 \\
1.66 \\
2.37\end{array}$ & $\begin{array}{c}\text { Per cent. } \\
49.02 \\
25.07 \\
16.34 \\
19.17 \\
20.26 \\
15.78 \\
26.77 \\
33.90\end{array}$ & $\begin{array}{c}\text { Per cent. } \\
13.42 \\
26.26 \\
32.56 \\
22.53 \\
20.66 \\
20.18 \\
20.23 \\
32.87\end{array}$ & $\underset{\Xi}{\Xi}$ \\
\hline Means 7.72 & 11.49 & 26.60 & 1.69 & 25.79 & 23.58 & 1.41 \\
\hline
\end{tabular}

The analyses given could be added to; but we have con. fined ourselves to analyses marle by our laboratory, the specimens analyzed having been collected by the writer as typical.

The analyses recorded are also selected in order to convey a view of the extremes of variation, which in the tufas are very great. Before discussing these variations we shall bring the general results together in a table of averages.

\begin{tabular}{|c|c|c|c|c|c|c|c|}
\hline Lavas. & Moisture. & $\begin{array}{l}\text { Combined } \\
\text { Water. }\end{array}$ & $\mathrm{SiO}_{2}$ & $\mathrm{Fe} O$ & $\mathrm{Fe}_{2} \mathrm{O}_{3}$ & $\begin{array}{lll}\mathrm{Al}_{2} & \mathrm{O}_{3}\end{array}$ & $\mathrm{CaO}$ \\
\hline & Per cent. & Per cent. & $\begin{array}{l}\text { Per } \\
\text { cent. }\end{array}$ & $\begin{array}{l}\text { Per } \\
\text { cent. }\end{array}$ & $\begin{array}{l}\text { Per } \\
\text { cent }\end{array}$ & $\begin{array}{l}\text { Per } \\
\text { cent. }\end{array}$ & $\begin{array}{l}\text { Per } \\
\text { cent }\end{array}$ \\
\hline Non-Hydrons ... & 0.41 & 0.13 & 49.12 & 8.43 & 4.04 & 21.94 & 9.24 \\
\hline $\begin{array}{l}\text { Hydrous... } \\
\text { Inifas ... }\end{array}$ & $\begin{array}{l}0.82 \\
7.72\end{array}$ & $\begin{array}{r}1.96 \\
11.49\end{array}$ & $\begin{array}{l}+1.66 \\
26.60\end{array}$ & $\begin{array}{l}8.66 \\
1.69\end{array}$ & $\begin{array}{r}5.62 \\
25.79\end{array}$ & $\begin{array}{l}17.06 \\
23.58\end{array}$ & $\begin{array}{l}8.23 \\
1.41\end{array}$ \\
\hline
\end{tabular}

As distinguished from the less crystalline, compact non-hydrous lavas, the hydrous lavas not infrequently show separations from the lava mass of silica, also of lime, which oceupy the larger vesicles, and indicate that an initial disintegration of the solid lavas has taken place. 
The analyses given of tufas convey to us an idea of the different degress of action of the steam and ardic vapors to which the blocks and fragments of solid lava were subjected in passing orer into the tufa mass. In one specimen nearly $40 \%$ of silica is still found, and in an. other the silica is reduced to merely $15 \%$. These very. significant variations in the silica and other elements we shall recur to in more detail under the heading of Chemical Action on Lavas After Emission.

Other effects, showing how intense the chemical action has been at the times of ejection of tufa lava materials, are seen in the almost complete oxydation of the ferrous iron, and in the remoral of the lime; results that are most instructive in the study of rock decomposition under the action of various causes.

The main conclusion that is drawn for us by the analyses, and which is set forth briefly in the table of arerages, may be expressed thus: Amongst Hawiian lavas are those which have been discharged from craters, flowing and cooling into rocks having the composition of normal basalts. Others, originally of the same composition, have undergone such alteration that they now compose rock masses having a radically different chemical. composition and color appearance. This alteration took place at the time of cjection, and under the action of chemical canses, and previous to the later action of sccondary canses of rock disintegration, such as "weathering," which has apparently been the only agent of disintegration of cortain of the normal lavas.

The effects of these primary chemical causes of disintegration which are exhibited in the appearance of the tufa masses, and marked by every rariation of colors be. tween the most vivid reds and jellows, and upon which the marks of fire are still as clear as upon bricks fresh 
from the kiln, will be further considered at a later time, and in their relation to the soils derived from the tufas. At present we shall consider other chemical causes that may have operated in determining the character of soils.

Cinemical Action on Litas after Emissiox.-In previous paragraphs we have considered the operation of steam and acid vapors that is going on at this time upon the lavas over large areas on the floor of the active crater at Kilauea, and over the areas surrounding the crater. We have shown that the solid lavas are undergoing rapid disintegration muler the chemical agents that alle operating, and are being resolred into the decomposition pro. ducts that have been set forth. The present purpose is to try to find out if these chemical causes, that are operating today at Kilauea, have operated in other localities, and over extensive areas, during previous periods of time. In the general review of the topography of the island, we spoke of the great craters, and of the general distribution of tufa cones, as seen from the Waimea plains. We must now come down, and with greater precision and detail, to the examination of the districts where, to-day, we are growing cane, and from which we have analyzed abmulant samples of soll for om guirlane in fertilization.

In the first place, it was necessary to note whether great rolcanic action has transpired during previous periods of time in the localities that are under considera. tion, as indicated by remains of extinct tufa cones, or whether all the lavas that have formed the soils in those localities have flowed from the great craters that are many miles away? Commencing in the district of Kan, on the final slopes of Mama Loa, around and between

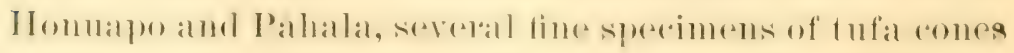
are located. In the immediate neighborhood of these 
cones the rock masses are marked by the strongest signo of alteration, and vast layers and deposits of rexl, yellow, and whitish earths are found. Leaving Kau, and pass. ing over by way of the Kilauea crater and down into the district of Hilo, on the other side of Mauna Loa, we come upon further centers of past volcanic action, and at levels close by, or up to 1,000 feet above the sea. One crater on the Kau side was noted where the bottom had dropped and let one-half of the cone down into the sea, thus revealing the grand throat of the crater, and the lurid colors of its interior, which raried from white, to yellow, to red, to black. At Hilo there is the cluster" of cones known locally as the "Halai Hills," three in number, and of moderate dimensions. Cane is now being planted at their feet. Above Wainaku are several small cones, and a series of profound caves, to which the writer's attention was called by $\mathrm{Mr}$. John Scott. At Onomea, which has been a center of rolcanic action of the most violent order, as shown by the great gulches and the irregular surfaces of the land, there is a further cluster of tufa cones that form a marked feature of the district. As we must return after this cursory description to discuss the special marks and characteristics of each of certain centers of past volcanic activity, we shall, for the present, merely state that in the comse of repeated rides between the town of Hilo and the grand gulch of Waipao, near Kukuihaele, the writer noted thirty-nine extinct craters, varying in size from areas of an acre, to enclosed basins containing several acres. During this ride of some sixty miles, more than fifty gulches were crossed, some of them of the first class in depth and grandeur. The thirty-nine craters noted are all upon levels at which cane is being planted, the basins of 
some of them actually bearing cane, and other growths. Along the same coast of Hawaii, in the district of Iiohala, are also found sereral latelal cones. It is thus seen that throwghout the districts reaching from Hilo to Ko. hala there are areas that are covered by the centers and indications of past rolcanic action, the evidences and results of which we have now to consider more minutely.

We have, in a case of specimens before us, small blocks of partially decomposed lava that wele taken by the writer from laras in place which form the irregular walls of sereral gulches. One collection of these blocks was from a gulch rumning through the sugar plantation above Wainaku; a second from Katraimui gulch near Onomea; and a third collection from a gulch below Kukaian. In each case, these blocks wele obtained by removing serelal feet of the front of the walls, and getting into small in. terior caves which were formed and left by past rolcanic morements. Some of these caves are amply large to move freely in, aut they consist usually of an arched roof over a more $01^{\circ}$ less level flont. The floors of the caves from rrich the three collections of partially decomposed lava were taken, were covered with a deposit, almost white in color, and from one-eighth to one-fonrth of an inch in thickness. The greatest care was taken to ascertain that this white material was brought up from the lava upon which it lies, aud not drained from the lava of the aroh above by the action of watel. Examination of the lara mnder the deposit indicated that the material had been brought up by ascending steam. Blocks or pieces of the lava forming the floor of the caves were taken ont, packed with care, and brought to on labolatory, and are pre. served, with the leposit of white material fresh and mndistmber mpon them. The freshmess of the deposit is 
remarkable; especially upon the specimens taken from the cave in the gulch above Wainaku. In the laboratory, this deposit is found to consist, in the first place, in more than one-half, of silica, considerable alumina, less iron, and small quantities of lime and sulphuric acid, no carbonic acid being present. An exact quantitative state. ment is unreliable, due to the crumbly state of the lava, from which the deposit cannot be removed without in. cluding portions of the lava.

In the search for such caves as we have described, and for deposits of materials that were possibly to be found in them, the writer was endeavoring to locate center's of past volcanic activity where chemical action upon emit. ted lavas may appear to have produced results corres. ponding to the effects observed to-day at Kilauea, where the action of acid vapors is seen to be resolving the laras into the products described in previoms paragraphs. 'The conditions of those caves that we have examined, which belong to a period of volcanic activity that prevailed in. definite ages ago, correspond to some of the conditions of location and environment marking the places of the present chemical action near the volcano, and the deposits upon the specimens of lava taken from those an. cient caves bear, in appearance, a most palpable re. sirmblance to siliceous deposits mpon the blocks of areom. posing lava that we took fresh from a center of extreme chemical action on the borders of the Kilauea crater a year ago, the analysis of which gave $70.8 \%$ of silica; 16.1\% of iron; $7.3 \%$ of alumina; $4.8 \%$ of lime, and $2.2 \%$ of sulphuric acid.

In addition to the cave deposits, there are other pro. ducts of lava-disintegration, muler the action of rhemis'al causes, which appear to correspond to materials into 
which the lavas are being resolved at Kilauea, the com. position of the latter we have already given. 'These are layer's and vast pockets of red and yellow earths, more or less consolidated, and also of earths whose colors vary from a dirty or yellowish white into actual blue. Al-

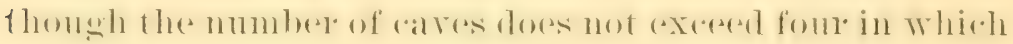
we have been able to identify the evidences of chemical action upon the lavas with a sufficient measure of reliability, the distribution of the other products of lava. decomposition by chemical agents is on a grand scale. We have examined and identified the sereral kinds of colored earths in all the gulches around Hilo and Papaikou. Further in the gulches named Kahalii, Kawainui, Kulaimanu, Kapaheehee, Kolekole, Hakalau, Maulua, Kapehu, Laupahoehoe, Kawali, Ookala, Kukaiau, Puuwhihalihai, Homokati, Kuknihatedr, and in the guldhes and cuttings in the district of Kohala. 'The recent cuttings made in the building of roads in the districts of Hama. kua and Kohala, likewise of Hilo, have furnished ample opportunity of noting the distribution of the earthy decomposition products under discussion. 'These earthy products are found in alternating red and yellow layers, of thicknesses varying from three inches to more than one foot. The layers repeat themselves, as shown by the cuttings, one series being found only two to six feet be. low the ground surface, whilst other layers are lying eren to twenty feet below the surface, and probably still deeper, which is indicated by their position in the bluff formations overlooking the sea in the Hamakua district. In addition to being seen in irregular layers, the red, yellow, and whitish substances exist in rast Arposits or porkets, whose masses maty he expressed in millions of tons. 'l'hese substances howerer, are not 
found miformly throughont all the lava formations. In what appear to have been center's of great volcanic and chemical action the formations have been largely resolved into these separate substances. But these center's are more or less acutely defined. They cease suddenly, and we come upon areas of formations that are under. going gradual disintegration, the dissolved materials be. ing borne away in rain waters into the sea as they are released. So that there are areas where the lavas and formations aplear to hare underome riolent disintegra. tion, and other rast areas where the evidences of such violent action are almost totally absent.

Further generalizing upon the extent of the areas where it is indicated that modes of violent chemical dis. integration have operated, and upon the appearances of the several decomposition-products, will not add to our knowledge. We must ascertain the chemical composition of these disintegration products, and then bring them into comparison with other similar products, the agents and modes of whose production we have identified.

At the time of the field examination of those products of disintegration, in the districts of the four islands, we took typical samples of the several kinds of earths. Some eighty samples, in all, were taken. On account of stress of work, this number was gone orer again by the writer, and reduced to forts samples, these replesenting localities and centers, bearing the marks of the most evident volcanic and chemical action, upon the four islands. The analyses, which are found in the following tables, are marle npou the materials as they rele found in place. The elements included are those whose variation in the sereral kinds of earths bears most closely up. on the immediate question. The estimation of the sul- 


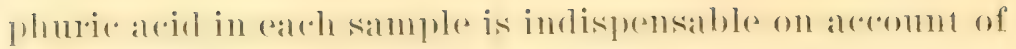
the part which it is believed to have played in the pro. cesses of rock-disintegration under discussion. 'The relative significance of the presence of sulphuric and car. bonic acids will be considered in a later paragraph.

In the first table we give the analyses of the decom. position-products found in localities on Hawaii, after which corresponding evidences of the same character of rock-disintenation by rheminal action that has transpired upon the other islands will be briefly given.

\section{LAVA DISINTEGRATION-PRODUCTS, ISLAND OF HAIVAII.}

\begin{tabular}{|c|c|c|c|c|c|c|c|c|c|c|}
\hline \multirow[t]{2}{*}{ Locality } & Color. & \begin{tabular}{|l|} 
Mois- \\
ture.
\end{tabular} & $\begin{array}{l}\text { Com- } \\
\text { bined } \\
\text { water }\end{array}$ & $\mathrm{SiO}_{2}$ & $\mathrm{Fe} O$ & $\mathrm{Fe}_{2} \mathrm{O}_{3}$ & $\mathrm{Al}_{2} \mathrm{O}_{3}$ & $\mathrm{CaO}$ & $\mathrm{SO}_{3}$ & $\mathrm{C} \mathrm{O}_{2}$ \\
\hline & & $\begin{array}{c}\text { Per } \\
\text { cent. }\end{array}$ & $\left|\begin{array}{c}\text { Per } \\
\text { cent. }\end{array}\right|$ & \begin{tabular}{|l} 
Per \\
cent.
\end{tabular} & $\begin{array}{c}\text { Per } \\
\text { cent }\end{array}$ & $\begin{array}{l}\text { Y'er } \\
\text { cent. }\end{array}$ & $\mid \begin{array}{c}\text { Per } \\
\text { cent. }\end{array}$ & \begin{tabular}{|l} 
Per \\
cent.
\end{tabular} & $\begin{array}{c}\text { Per } \\
\text { cent. }\end{array}$ & $\begin{array}{c}\text { Per } \\
\text { cent. }\end{array}$ \\
\hline Gilo & Brown. & 36.32 & 11.70 & 11.53 & 4.27 & 10.45 & 19.42 & 1.25 & 0.67 & none \\
\hline & Red & 19.82 & 2. 9.64 & 21.80 & 0.89 & 23.04 & 22.84 & 0.49 & 0.30 & 0.10 \\
\hline & Yellow & 9.45 & $\begin{array}{ll}5 & 15.56\end{array}$ & 17.66 & $3.6 t$ & 20.64 & 30.99 & 0.60 & 0.33 & 0.25 \\
\hline $\mathrm{mom}$ & Red .. & 17.51 & $\begin{array}{l}1.74 \\
\end{array}$ & 25.10 & 0.49 & ) 31.12 & 18.95 & 0.40 & trace & none \\
\hline ilo & Red . & 28.52 & 5.84 & 16.27 & 80.98 & 25.28 & 21.42 & 0.47 & 0.07 & none \\
\hline & & 16.69 & 535 & 26.17 & 0.70 & 2750 & 21.91 & 10.22 & trace & none \\
\hline & Yellow ... & 4.15 & 27.85 & 2.26 & 0.77 & 2.40 & 61.12 & 2030 & 0.50 & non \\
\hline La & Light gray & 30.08 & 10.80 & 27.88 & 0.61 & $\begin{array}{l}1.86 \\
-1.8\end{array}$ & 28.00 & 0.62 & none & 0.10 \\
\hline L & Red ..... & 15.25 & 4.51 & 26.60 & 0.81 & 36.00 & 15.14 & 4.49 & 0.40 & 0.25 \\
\hline 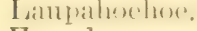 & Whitislı & 2.47 & $3(10.52$ & 2.11 & 1.50 & 1 , fit & $.59 \times 1$ & 10.50 & 10.34 & $(1.21)$ \\
\hline akui & Gr: & 7.66 & | 5.79 & 37,40 & 5.74 & 12.24 & 18.30 & 0.30 & 0.48 & |none \\
\hline & & $13: 26$ & $11.7 !$ & 31.0 .4 & 1.26 & 4.40 & ) 3.t6h & $11, \ldots$ & 0.11 & wone \\
\hline & & 5.16 & $2.5 .<;$ & 10.911 & 01.77 & 7.36 & ; 15.11 & 10.45 & $\left(1.3,3^{\prime}\right.$ & 'mome \\
\hline & disish & 9.54 & $11 .(1: 3$ & 34.37 & $1 .+2$ & 16.100 & 25.42 & 2.19 & 1 1.50! & mone \\
\hline
\end{tabular}

These analyses were made precisely the same as those of the lavas, and thus the data express the amount of the elements in the total substance.

As the Island of Hawaii, excepting probably the Kio. hala division, is the most recent in the group of islands, and its products the freshest, we shall call attention to the table of data before proceeding further. Without noteworthy exceptions, it is seen that where the "combin. ed water" is high, the proportion of alumina is also high, 
and in instances enolmous! The earths having these high contents of alumina and combined water are a dirty white, gray, or yellow in color. When glowed, for the remoral of the combined water, the color may remain yellow, or becomes pink, or goes over instantly into a vivid red, which changes are determined by the proportion of iron and the form in which it is present. The yellow hydrate of iron at once becomes red on glowing, but the silicate changes slowly, and very little.

Very striking is the variation in the contents of silica, and of iron, in the substances. In examples we find the silica as low as $2 \%$, and the iron as high as $37 \%$; yet in. stances are found where the silica and iron are both reduced to almost nothing, and the alumina forming almost the total of the earth. It has also to be specially understood and kept in mind that these substances which are so totally different in their composition, are fouml in the closest contiguity to each other. The Ookala "red" and "yellow," although each represents thousands of tons of material, are lying near to each other, yet separated by acute lines of division. It is also, and even more strikingly, the case with the "red" and whitish earths taken in the locality of Laupahoehoe. The writer, in some cases, has taken samples of "bright red," and of "whitish yellow;" from heaps of these earths not more than three feet apart. This close contiguity of earths of such totally diflerent chemical compositions inclicatea most clearly that a cause other than "weathering" has operated in the rock-disintegration.

Istand of MaUt.-This island is said to be older than Hawaii. To the writer, the indications of age resemble those of the Kohala division of Hawaii.

Three of the analyses are of earths from the region of 
greatest volcanic activity, following the line of lateral cones that descend the slopes of the grand crater of Hale. akala to the sea. 'The writer located some six of these lateral or tufa cones. 'I'wo more are of products separat. ing ont in the disintegration of the laras of West Mani, which was separated formerly from East Maui by a channel, in whose place now lies the isthmus that ties the two great crater mountaius together.

The border's of West Maui are skirted in localities by coral formations, which formations underlie some of the later lava flows. It is also indicated, as upon the Island of Oahu, that latel voleanic activities have disturbed the underying coral, or limestone, whereupon the escape of steam and rapor's from below took place, bringing up rast quantities of earbonate of lime, of silica, with small amounts of iron and alumina. The deposits of these materials are a feature of the mountain slopes of West Mani running down to the bay of Lahaina, and the writer has frequently been asked by people passing the island on steamer's "what the deposits are?" The districts be. ing small, the number of analyses has been reduced to a minimum; ret numerous samples of earths were taken corresponding to these analyzed.

LAVA DISIN'IEGRATION-PRODUCTS, ISLAND OF MAUT.

\begin{tabular}{|c|c|c|c|c|c|c|c|c|c|c|}
\hline Locality. & Color. & $\begin{array}{l}\text { Mois- } \\
\text { ture. }\end{array}$ & $\begin{array}{c}\text { Com- } \\
\text { bined } \\
\text { water } \\
\text { ete. }\end{array}$ & $\mathrm{Si} \mathrm{O}$ & $\mathrm{F} \in \mathrm{O}$ & $\mathrm{Fe}_{2} \mathrm{O}_{3}$ & $\mathrm{Al}_{2} \mathrm{O}_{3}$ & $\mathrm{Ca} O$ & $\mathrm{SO}_{3}$ & $\mathrm{CO}_{2}$ \\
\hline & & $\begin{array}{l}\text { Per } \\
\text { cent. }\end{array}$ & $\left|\begin{array}{c}\text { Per } \\
\text { cent. }\end{array}\right|$ & \begin{tabular}{|l|} 
Per \\
cent.
\end{tabular} & $\begin{array}{l}\text { Per } \\
\text { cent. }\end{array}$ & \begin{tabular}{|} 
Per \\
cent.
\end{tabular} & $\left|\begin{array}{c}\text { Per } \\
\text { cent. }\end{array}\right|$ & \begin{tabular}{|} 
Per \\
cent.
\end{tabular} & $\begin{array}{l}\text { Fer } \\
\text { cent. }\end{array}$ & $\begin{array}{l}\text { Per } \\
\text { cent. }\end{array}$ \\
\hline Paia ...... & red ...... & 10.85 & 18.83 & 29.90 & 0.22 & 23.16 & 26.00 & 0.31 & 0.31 & none \\
\hline Maliawao & $\operatorname{red} . . . .$. & 12.60 & 13.39 & 5.66 & 3.92 & 58.00 & 5.06 & 0.61 & 0.03 & none \\
\hline MIakawa & yellow... . & 30.02 & 32.63 & 7.66 & 0.00 & 1.50 & .29 .06 & 0.30 & 0.02 & none \\
\hline Olowalu ... & white .... & 3.44 & 13.85 & 1080 & trace & trace & 3.06 & 37.36 & 0.05 & 32.66 \\
\hline Lahaina ... & white .... & 1.66 & 11.51 & 12.18 & 0.80 & 4.32 & 5.28 & 40.24 & 0.10 & 30.90 \\
\hline
\end{tabular}


The "red" and "yellow" earths from Makawao were taken by the writer from places only thress yolds alpart; but they represent bulks of thousands of tons. The crater region of Makatrao abounds with thefe diffrent kinds of earths, in which the guava tree is flomrishing; and this tree is preparing the earths for grom ths of a more dealinate nature.

The white deposits in the districts of Olowalu and La. haina are not to be regarded as lava disintegration-pro. ducts. Their prevalence, however, indicates to what an extent the areas of lava flows have been marked, during a past period, by escaping steam and vapor's emanating from the depths below.

IsLAND of OAHU.-This island being the chief island of residence, its volcanoes are better known than others. Dana says the island is derived from the operations of two craters of the "first class." We are able, howerer, to locate not less than twenty lateral or tufa cones, cer. tain of which are of notable dimensions. Better than upon eren the younger islands can be observed the marks and results of escaping steam and vapors upon the lavas after emission from the craters. The slopes of Diamond Head and of Punchbowl are white with deposits of silica and carbonate of lime, and the fractures of the lava masses, and large fissures, are filled up with these materials that have been left behind by the escaping vapors.

As on West Maui, the presence of more or less of carbonate of lime in the deposits is due to limestone or coral formations upon which the latest exuptions orerflored. Even the lavas of these districts contain nearly $15 \%$ of lime, indicating that the limestone below was melted and mixed up in the up-coming magma, within which it is 
now seen in white clusters of beantifully crystallized carbonate with some silica.

The following analyses are of disintegration-products of lavas from localitites where the coral has not entered into their composition.

DECOMPOSITION-PRODUC'S OF LAVA, ISLAND OF OAHU.

\begin{tabular}{|c|c|c|c|c|c|c|c|c|c|c|}
\hline Loenlity. & Color. & $\begin{array}{l}\text { Mois- } \\
\text { ture. }\end{array}$ & $\begin{array}{l}\text { Com- } \\
\text { bined } \\
\text { water }\end{array}$ & $\mathrm{Si} O_{2}$ & $\mathrm{FeO}$ & $\mathrm{Fe}_{2} \mathrm{O}_{3}$ & $\mathrm{Al}_{2} \mathrm{O}_{3}$ & $\mathrm{CaO}$ & $\mathrm{SO}_{3}$ & $\mathrm{O}_{2}$ \\
\hline & & $\begin{array}{l}\text { Per } \\
\text { cent. }\end{array}$ & $\mid \begin{array}{c}\text { Per } \\
\text { cent. }\end{array}$ & $\begin{array}{c}\text { Per } \\
\text { cent. }\end{array}$ & $\mid \begin{array}{c}\text { Fee" } \\
\text { cent. }\end{array}$ & $\begin{array}{c}\text { I'er } \\
\text { eent. }\end{array}$ & $\begin{array}{l}\text { Fer } \\
\text { cent }\end{array}$ & $\begin{array}{c}\text { Per } \\
\text { cent }\end{array}$ & $\mid \begin{array}{c}P e \\
\text { cent }\end{array}$ & $\begin{array}{l}\text { Per } \\
\text { cent. }\end{array}$ \\
\hline & & 15.10 & 10.74 & 29.14 & 1.60 & 15.20 & 26.10 & 0.40 & 0.10 & none \\
\hline & & & & & 0.44 & 8.45 & 52.10 & 0.43 & 0.20 & \\
\hline & & & $21.0 t$ & $12.8 t$ & 1.99 & 13.29 & 43.90 & 0.53 & 0.35 & nor \\
\hline & & 12.11 & $\begin{array}{r}9.57 \\
\end{array}$ & 33.96 & 75 & 11.14 & 30.14 & 0.40 & 0.20 & none \\
\hline & & & 10.89 & 7.52 & 1.40 & 70.40 & 6.30 & 0.62 & 0.56 & non \\
\hline & & 1.60 & 4.78 & 87.89 & 0.69 & 1.85 & 2.33 & 0.20 & 0.07 & 0.46 \\
\hline & & & 9.8 & & 0.00 & 9.92 & 19.48 & & 0.15 & nove \\
\hline & & 7. & 1.15 & 29.29 & 1.80 & 26.06 & 22.07 & 1.88 & 1.53 & non \\
\hline & 年 & 5.21 & 6.84 & 33.70 & 2.56 & 18.66 & 23.71 & $\mid 1.48$ & 1.15 & none \\
\hline
\end{tabular}

These data repeat the indications set forth in the examination of the substances from Mani and Hawaii. The Kokoloea substances were taken from places separated only a few yards from each other, yet the one is largely an alumina compound, whilst the other contains orer $70 \%$ of iron oxide, of which we shall speak later. SpecialIy noteworthy are the high amounts of silica found in the Ewa products that were taken by the writer from two deposits that are still in a very fresh condition. The large amounts of sulphuric acid found in certain of tỉe products furnish a clear indication that the steam vapors that acted in the disintegration of the lavas were highly sulphurous.

Istaxd of Kindt.-The geologists appear to agree in considering Kanai the oldest island in the group. We have reason to consider, however, that whilst Kauai may 
have appeared above the ocean before any of the islands, volcanic activity continued upon it after the other islands came into existence. But the greater age of the formations and lavas is indicated by given disintegration-products notwithstanding.

Geologists cannot locate with certainty the location of the pimary ateres which lain the fommations, and built up the main part of the structure of the island. The centers of lateral crater action, however, are almost more definitely markerl than upon the yomeng islands. At the north end of the island in the district of Kilauea, the lavas, and the soils derived from them, indicate a past period of extreme lateral activity. Crater hill, one part of which appears to have dropped down below the sea, leaving a bluff wall which had been the interior of the throat of the crater, is, with other tufa cones, an abiding evidence of past volcanic action. In the district of Kealia the grand gulches and tufa cones repeat the same state. ment. The Kilohana crater gave forth much of the material that has formed the soils in the district of Lihne, althomgh all Lihue soils do not appear to have been derir. ed from one source. From Lihue we pass on to Koloa, where we come upon a region of past volcanic activity that is almost without a parallel. Within an area of a few thousand acres are seen what have been nine, and possibly eleven, crater cones; one line of which-the "Dutton craters"-corresponds to the Diamond Head series on Oahu, and to the Makawao chain of cones on Maиi.

Analyses have been made of only seven products from Kanai but these are so extremely distinetive in charater that further aualyses could hamelly ard to the indirations that they are calculated to convey. 
DECOMPOSITION-PRODUCIS OF LAVA, ISLAND OF KAUAI.

\begin{tabular}{|c|c|c|c|c|c|c|c|c|c|c|}
\hline Locality. & Color. & $\begin{array}{l}\text { Mois- } \\
\text { ture. }\end{array}$ & $\begin{array}{l}\text { Com- } \\
\text { bined } \\
\text { water }\end{array}$ & $\mathrm{SiO}_{2}$ & FeO & $\mathrm{He}=\mathrm{O}_{3}$ & $\mathrm{Al}_{2} \mathrm{O}_{3}$ & $\mathrm{CaO}$ & $\mathrm{SO}_{3}$ & $\mathrm{Co}_{2}$ \\
\hline & & $\begin{array}{l}\text { Per } \\
\text { cent. }\end{array}$ & $\begin{array}{l}\text { l'er } \\
\text { cent }\end{array}$ & $\begin{array}{l}\text { Per } \\
\text { cent. }\end{array}$ & $\begin{array}{l}\text { l'er } \\
\text { cent }\end{array}$ & $\begin{array}{l}\text { Per } \\
\text { cent. }\end{array}$ & $\begin{array}{l}\text { Per } \\
\text { cent. }\end{array}$ & $\begin{array}{l}\text { Yer } \\
\text { cent. }\end{array}$ & $\begin{array}{l}\text { Per } \\
\text { cent. }\end{array}$ & $\begin{array}{l}\text { Per } \\
\text { cent. }\end{array}$ \\
\hline Ḱolon & White. & 444 & 15.55 & 231 & 0.00 & 0.85 & 109 & 31.21 & 44.65 & none \\
\hline & Yellow... & 10.13 & $10 . \pm 1$ & 32.52 & 0.94 & 11.37 & $2+17$ & 3.59 & 4.65 & 0.14 \\
\hline Kol & Yellowisl & 24.88 & 5.87 & 43.45 & 0.00 & $3.8 t$ & 18.07 & 0.46 & trace & none \\
\hline & White & 830 & 12.47 & +2.2 & 0.00 & 2.24 & 333.76 & 0.25 & 0.10 & none \\
\hline Lilun & Red & 4.37 & 10.23 & 9.10 & 0.84 & 63.68 & 9.72 & 0.66 & $0.5 t$ & none \\
\hline & Red & 2.24 & 10.41 & 12.95 & 1.92 & 62.72 & 8.22 & 0.50 & trace & none \\
\hline & & $5.3 \pm$ & 8.90 & $\begin{array}{l}4.96 \\
\end{array}$ & 1.98 & $67.06^{\circ}$ & 11.19 & 0.32 & 0.59 & none \\
\hline
\end{tabular}

We did not succeed in finding distinct siliceous deposits on the Island of Kanai. The composition of the other products, however, indicate the enormous amount of silica that has been released by the disintegration of the lava, and removed elsewhere. 'The undecomposed, resicular lavas in the region of Kíoloa and Lihue are quite remarkable for the amounts of pure silica contained in the vesicles, and deposited on the surfaces of the lava. In Koloa we have an example in process of liatinivation, and on a large scale. The writer has in his collection a specimen of one hundred pounds in weight, obtained with the assistance of $\mathrm{Mr}$. Anton Cropp, in which is beantifully illustrated the mode of coming together of the alumina and silica, and the production of an almost theoretically pure kaolin, and the separation of the other elements of the decomposing lava.

Upon the plain of Mahanlepu, in the Koloa district, we found the most extraordinary piece of evidence of pre. vious roleanic action, and of the mode of the subsequent disintegration of the lavas. Side by side, and on areas extending over a considerable portion of the plain, are found deposits of red and yellow earths. The yellow earth contains no less than 5.82\%, upon its dry weight, 
of sulphuric acid, and sulphate of lime is found in crys. talline form, and amounts to over $9 \%$ of the earth, from which it is separating out almost chemically pure.

In the district of Lihne, Kealia and Kilamea, and in what have been centers of extreme volcanic activity, the separation of the elements which formed the lavas has proceeded to more ultimate lengths. The layers of red earth, some of which are found in deep cuttings, and twenty to thirty feet below the land surface, and others only four feet below the surface, have consolidated into hard concretions of almost pure iron ore, or hematite. These concretions we have only succeeded in finding on the two older islands-Oahu and Kauai-and ther, with the kaolinization proceeding at Koloa, indicate the con. tinuance of lava-disintegration, and separation of the products, under the agency of "simple weathering," and after the chemical causes, of which we are speaking, had ceased. It is understood that whatever may have been the character and extent of the primary chemical action upon lavas, the disintegration has been continued and completed by the sereral climatic influences that are ex. pressed by the term_- "weathering."

Having examined the products from each of the four islambls which may be comsiflered as evidence of the operattion of chemical causes in the disintegration of lavas in certain localities, we shall now bring these ancient pro. ducts into comparison with the substances that are being produced today at Kilauea, on the borders of the actire crater, by the action of sulphurous steam on the lavas. Te mas here add that, in addition to the samples represented by the analyses recorded, we have made qualitative examinations of the other almost chemically pure samples of grpsum, siliceous, and other compounds in 
order to justify any allusion to such substances that it did not appear necessary to examine quantitatively. In the following comparisons of recent and ancient products of disintegration the data give the relative amounts of the elements free from water and volatile matters. 'This is necessary on account of the extreme variation in the proportions of volatile matter's in the several substances, and in order to further compare the composition of the sereral products with that of the original lava, which is almost free from volatile borlies.

YELLOWISH-WHITE-COLORED, SILICEOUS PRODUCTS.

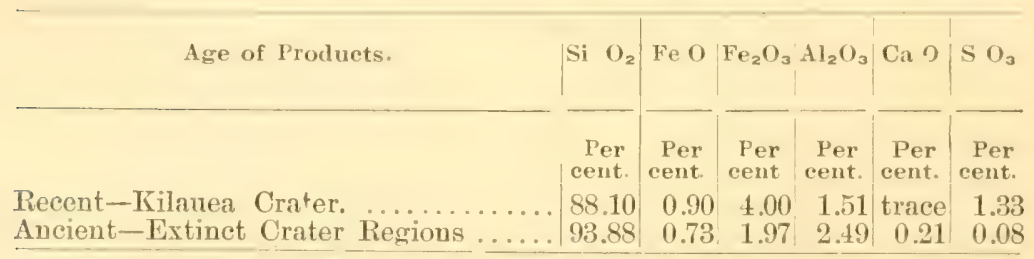

GRAY-COLORED, SILICEOUS PRODUCTS.

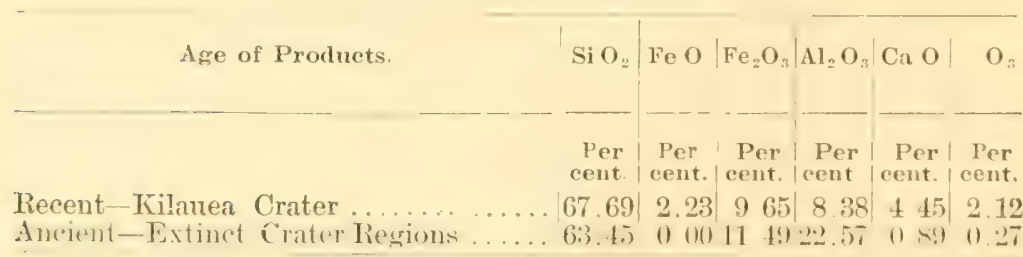

In the following comparison, lime carbonates are ex. cluded from the arerage of "ancient" products. As we have already explained, these carbonates are derised from lime formations underlying lava flows, and are not true disintegration-products of lava. 
WHITE, CALCAREOUS PRODUCTS (GYPSUM).

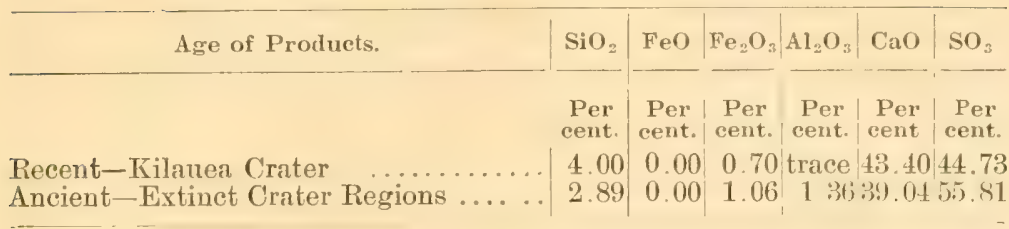

It is difficult to make a comparison, of any value, be. tween the alum products that are being formed from the decomposing lava at the Kilauea crater with ancient deposits in which alumina predominates. The Kilanea alum deposits contain, in addition to iron sulphates, con. siderable sulphates of magnesium and of the alkalies. In the ancient products these sulphates halve been alunost washed away, which has resulted in increasing the amounts of alumina and silica.

GRAY, ALUMTNA PRODUCT'S.

\begin{tabular}{c|c|c|c|c|c|c}
\hline Age of Products. & $\mathrm{SiO}_{2}$ & $\mathrm{FeO}$ & $\mathrm{Fe}_{2} \mathrm{O}_{3}$ & $\mathrm{Ca} \mathrm{O}$ & $\mathrm{Al}_{2} \mathrm{O}_{3}$ & $\mathrm{SO}_{3}$ and $\mathrm{H}_{2}$ \\
\hline & $\begin{array}{c}\text { Per } \\
\text { cent }\end{array}$ & $\begin{array}{c}\text { Per } \\
\text { cent. }\end{array}$ & $\begin{array}{c}\text { Per } \\
\text { cent. }\end{array}$ & $\begin{array}{c}\text { Per } \\
\text { cent. }\end{array}$ & $\begin{array}{c}\text { Per } \\
\text { cent. }\end{array}$ & Per cent. \\
Recent-Kilanea Crater ........ & 0.80 & 0.00 & 12.30 & 0.50 & 26 & 45.65 \\
Ancient-Extinct Crater Regions & 8.97 & 1.44 & 7.80 & 0.34 & 45.5 & 25.60 \\
\hline
\end{tabular}

As already remarked, these ancient alumina products do not admit of close comparison. They also unquestion. ably owe their present composition to slow processes of change that followed the primary chemical action upon the lavas. Moreover, it must be borne in mind that alumina products, resembling these under discussion have resulted from the decomposition of rocks in older countries where it has not yet been shown that rhemical causes of disintegration have played any part.

In the following and last table we bring into com. 
parison the red-earth products obtained fresh from the active crater where they are now forming, and the red

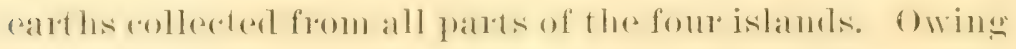
to the great variation in the ancient red products, which variation appears to relate to the variation in age, we give first, the composition of the recent red product from Kilauea. Second, the composition of an ancient red earth that corresponds most closely with the recent product. Third, the ancient red product that contains the least amount of iron oxide. Fourth, the ancient red product that contains the largest amount of iron oxide. Lastly the mean composition of all the red earths. 'This division is made in order that the variation in the compo. sition of these red earths shall be understood, and for the further reason, that these earths are a factor of importance in the composition of some soils.

RED, IRON PRODUCTS.

\begin{tabular}{|c|c|c|c|c|c|}
\hline Agre and State of Produets. & $\left|\overrightarrow{\mathrm{SiO}_{2}}\right|$ & $\mathrm{Fe}_{2} \mathrm{O}_{3}$ & $\mathrm{Al}_{2} \mathrm{O}_{3}$ & $\mathrm{CaO}$ & $\mathrm{SO}_{3}$ \\
\hline & $\begin{array}{c}\text { Per } \\
\text { cent. }\end{array}$ & $\begin{array}{l}\text { Per } \\
\text { cent. }\end{array}$ & $\begin{array}{c}\text { Per } \\
\text { cent. }\end{array}$ & $\begin{array}{l}\text { Per } \\
\text { cent. }\end{array}$ & $\begin{array}{l}\text { Per } \\
\text { cent. }\end{array}$ \\
\hline Recent--Iilawea Crater Product. & $32.50 \mid$ & 44.50 & 18.10 & 0.20 & 1.57 \\
\hline Ancient-Corresponding Product...... & 33.15 & 44.86 & 18.87 & 0.60 & 0.50 \\
\hline Ancient Minimum Iron oxide content ...... & 4290 & 19.48 & 28.98 & 2.45 & 1.68 \\
\hline Ancient-MIaximum Iron oxide content..... & 7.65 & 8368 & 6.8 .1 & 0.82 & 0.01 \\
\hline Ancient-Mean of Red Products........... & 28.71 & 47.32 & 21.80 & 0.90 & 0.60 \\
\hline
\end{tabular}

The examination of the products of lava-decomposition of an earlier period, and the comparison of those with the porturts of disintegration that are being formed, al the present time, in the region of the active crater at Kilauea, have led to very significant results. The location of the ancient products in what have been centers of past, ex. treme volsanic aletivity; the matred resemblanes of these

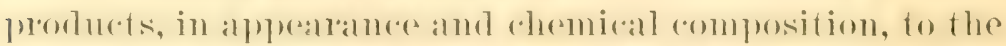
sulstances now in the ale of formation from disintegrat. 
ing lavas, by visible processes, - all these phenomena indicate that the "recent" and the "ancient" products, under discussion, have had a similar origin. Moreover, these phenomena indicate that in the disintegution of the older lavas, chemical causes have exercised a strong action, over extensive areas, and previous to the later action of "simple weathering," the results of which will be found in the present character of the soils derived from them.

LATERITES: TIIEIR OCMRRENCE ANT ORIGIX.

In the previous paragraphs we have endeavored to compare the products of lava-disintegration of a past period with the substances into which the same kinds of laras are being resolved to-day, but we have not, so far, attempted to definitely designate those products.

It is evident, however, that in the highly siliceous, light-yellow colored, products we have substances that will ultimately consoliflate into siliceous samd-stones, examples of which are already found in a very developed crystalline state. Further the calcareous products have, and are still resolving themselves into definite deposits of almost pure grpsum and carbonate of lime; whilst the alumina is separating as masses having a remarkable degree of puritr, excesling that of the banderes of France and Ireland. Each of these products has a definite char. arter, and they all differ radically from the "red earths;" which, from their appearance, physical character, and rhemical composition may come muler the designation of Taterites.

Sir Charles Lyell describes laterite as a "red or brick. like rock, composed of silicate of alumina and oxide of 
iron;" "Thich description exactly agrees with the chemical composition of the red product that we have found to be forming, at the present time, near the active crater, and of the red earths collected from centers of past roleanic activity.

Concerning the occurrence and geographic distribu. tion of the laterites, Lyell says further, "The red layers, called 'ochre beds,' lividing the lavas of the Giants Cause. way (England) and the Inner Hebrides, appear to be analogous to the laterites of India, which were found by Delesse to be basalt (trap) impregnated with red oxide of iron, and in part reduced to kaolin." Blandford in his "Geology of India," speaks of "high level laterite as nondetrital, or iron clay ;" which Posewitz says bears a closer resemblance to the laterites examined by him in Banga than do those which occur in given regions in Africa, where they were examined by Peschuel-Losche, and are described by Sachsse in his "Lehrbuch der Agriculturchemie." Wohltmann speaks of a laterite formation from volcanic, basalt rocks in Liberia. Credner treats of the laterites of South America, and compares these with the laterites of India. These substances, which are better known as "ochres," are found distributed over most sec. tions of our globe, and independently of the present climatic conditions; although, at this place, it must be borne in mind that comntries which are distinguished today by temperate climates, during a previons period exhibited the conditions of tropic lands. In the British Islands, orer Europe, down to the Mediterranean, the "ochres" are found, and ntilized in the arts and manu. factures. Over North America vast deposits of "red ochres" are widely known, and which, a manufacturer of mineral paints in a city in the United States says, 
"are the same thing as the red ochres sent to us from the Hawaiian Islands, for which we have no use, as we have too. much near home."

At present, we are not able to judge to what extent it may ultimately be found the rule, but the occurrence of the laterites, has been largely found in connection with igneous rocks. Lyell not only says that the "red ochres" in England "divide the lavas;" but contimues "we feel sure that the rock of Staffa, and that of the Giants Causeway (England), called basalt, is volcanic, because it agrees in chemical composition with streams of lava. known to have flowed from craters." Lyell says further "these basaltic and other igneous rocks are associated with beds of tufa in various parts of the British Isles;" and "the absence of cones and craters in Englaud may be due to the eruptions having been submarine." In Madeira and the Canary Islands, Lyell again says the lava flows are divided by red layers of laterite. Blanford says the "high-level" laterites of Central and Western India are found lying upon trap rockis baskalt), that alre of igneous origin. In this matter, howerer, our knowledge is not exact and universal enough to speak emphatically on a relation of the laterites to rocks of voleanic origin. Moreover, it appears from the observations of other in. vestigators that laterites occur where it does not yet appear that igneous rocks are found.

Bearing upon the question of the origin of the laterites, Lyell says "the red bands or layers of laterite are prob. ably ancient soils formed by the decomposition of the surfaces of lava currents. These red soils may hare been colored red in the atmosphere, or burnt into red brick by the overflowing of heated lavas." Posewitz considers the formation of laterites is due to the supreficial wath- 
ering of rocks and soils. Wohitmann says "the mode by which the laterites have been formed is not at all under. stood. Some have erroneously taken these products to be a result of the action of sea water on rocks, or sedimentaly deposits from sweet water; whilst others have as erroneously considered them in some way pos. sibly connected with volcanic movements." Again he says "it must bo reatroded as a geolonical feature of late. rite, that it has only been formed where the processes of wathering and leathing have gone on for thomsands of rears. 'The expiration of numberless thousands of years of the action of weathering upon the materials of the earths' crust was an absolute necessity in the formation of the laterites."

Concerning the origin of the red ochres or laterites of the Hawaiian Islands we do not need to go into a further lengthy distussion. The minut description of the disin. tegration of lavas in the region of the active crater at Kilanea, that is proceeding at this time, whereby the solid lava is being resolved, by the action of sulphurous steam, into the sereral products of decomposition, of which a red earth, or laterite, is a prominent one, does not need to be repeated. Also our account of the distribution of enters of past voluanir artion over latere areas, and the comparison of the "ancient" products of lava disintegration with the "recent" products that can be seen and obtained to-day - all these things place before

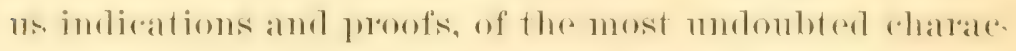
ter', that the formation of laterites upon the Hawaiian Islands has been, and is still being, due to the intense aretion of ard vapors upon latras, whereby these are being resolved into the siliceous, calcareous and earthy bodies which we have already fully described. 
In evidence of the mode by which these "red earths" have been formed in past periods, it was in the first degree important to bear in mind the agents by whose action the formation could have been carried on. For that reason, in the examination of all the products of lava-disintegration the sulphuric and carbonic acids were invariably determined. If the formation of the laterite had been due to the superficial action of weathering upon laras and soils, the mole active agent in the process must have been carbonic acid, derived from regetable decay, and evidence of its presence and action might be deduced from iron carbonates found in the products. If, on the other hand, the rock-disintegration had been primarils caused by the action of acirl vapols escaping from below, and sulphurous or sulphuric acid had been, as it is found to-day, the acid element in the steam and rapors, then it was expected that sulphuric acid might be foumd in the laterites and other disintegration-products, and especially in such as were found at great depths from the surface, and which rains had not leached.

If we recur to the analyses of the "red earths" found in localities upon the four islands we see that in most of the products no carbonic acid, but very notable quantities of sulphuric acid were present. To save the reader the necessity of looking back over the several tables we reproduce the sulphuric acid contents of the recent "red earth" (laterite) forming at the present time at Kilauea, and of certain of the laterites formed during earier periods of roleanic action at centres over large areas of all the islands, to which are added the amounts of the acid also contained by certain of the kaolin products, and the highly siliceous separation-products, commonly call- 
ed "yellow ochres," and also classed as "yellow laterites," as a result of confusion.

Age and Nature of Products. Locality Sulphuric

liecent-red laterite (now forming). Kilanea Crater ..... 1.57 per cent.

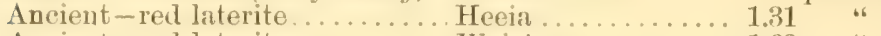

Ancient-red laterite.......... Waialıa......... 1.68 "6

Ancient-red laterite...........Kohala.......... 1.68 "

Ancient-red laterite..........Kokoloea......... 0.65 "

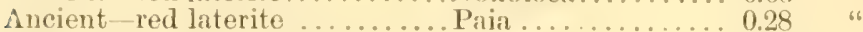

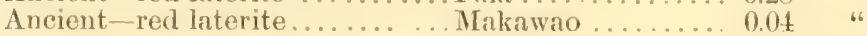

Mean of all Ancient red laterites.............. 0.61 6

These red laterites vary in physical state from plastic to solid concretionary deposits. Four of these contain

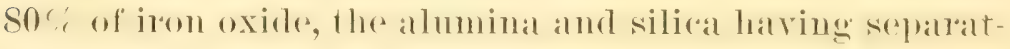
ed ont.

Age and Nature of Products. Locality. Sulphuric

Recent-yellow earth (now forming). Kilauea Crater. . . . 1.33 per cent.

Ancient-yellow earth ........ Hilo .......... 1.29 ".

Ancient-yellow earth.........Laupahoehoe ..... 0.57 "

Ancient-yellow earth ......... Ookala ......... 0.71 6

An.ient - Clay or Kaolin.......... Koloa .......... 5.85 "

Ancient-(1ay . ......... Wainaku ....... 0.41 "

Recent-Gypsum (now forming) .. Kilauea Crater...44.73 "

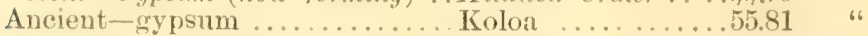

The ancient red laterites were all found to contain sulphuric acid and certain of them, which have been pro. tected from the leaching action of rain, contain even more than is found in the fresh laterites now forming under the action of the sulphurous steam at the Kilanea crater.

We had persuaded ourselves that the layers of red laterite, lying at a depth of from two to fou feet below the land surface, mist have been deposited by the action of carbonic acid, derived from decaying regetable mat. ter, on the iron in the soils. In most of the laterites, hom. ever, no carbonic acid was found, and where the acid 
was met with, it was in products where coral limestone was lying in the neighborhood. But the absence of carbonic acid in the deposits or layers of laterite is no abso. lute proof that the deposition was not caused by that agent. The carbonate of iron, when deposited, would part with the acid, and the iron would revert to the oxide form in which it is now found; the laterites thus distinctly differing in their behaviour from the concre. tions known as "hardpans," one example of these concretions containing $30.26 \% \mathrm{Si} \mathrm{O} ; 5.83 \% \mathrm{Fe}_{2} \mathrm{O}_{23} ; 14.83 \%$

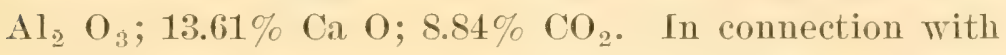
the formation of laterites that are lying within two feet of the surface, we have to bear in mind that the red late. rites formed, and forming near the active crater are little more than a foot below the surface, but are marked by crestals of sulphur, which attest their mode of formation. Nevertheless, we are still impressed that carbonic acid has also acted as an agent in causing the deposition of the laterites in given localities, although it has not yet been possible to obtain actual evidence to confirm the persuasion.

Concerning the action of rainfall and temperature in the matter of laterite formation, the climatic conlitions of the present time furnish no conclusive indications. The red laterites, and other disintegration products of the lavas, are found on the windward and leeward sides of the islands, and in the dry districts of Kan, Kohala, Paia, Waimea, and Honolulu, as well as in the wet dis. trict of Hilo, and the moderately moist districts of Kilanea, Koloa, Hana and South Hamakua.

In concluding our observations upon the operation of chemical action in the disintegration of lavas on these islands, we refer once more to the extensive areas which 


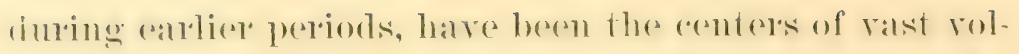
canic action. Lateral cones have been in action upon the slopes of the great craters, and over a large part of the surfaces of the islands. From these cones, tufa lavas were poured forth, silturated with stealm and aldid valuols, which cansed the lava masses to undergo extreme altera. tion in chemical composition at the time of ejection. Through fratelures amd fissures of the rejected lavas, steam,

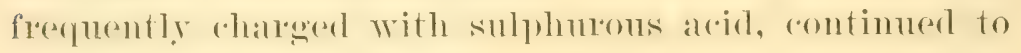
escape, and these vapors carried on the alteration primarily causer in the tufas, and appear also to have operated upon areas of solid lavas, which were dis. charext withont alteration, ansing results in disintegrar tion that are not comparable with the effects of "simple weathering."

The examination of the disintegration-products has not only fumished indications of the broad scale of aleas orer which chemiral causes have acted in the decomposing of the lavas, they have led to the observation that the formation of laterite has been, and is still being, due to the operation of the same chemical action. For whatever other causes or agents may have operated, it appears, without doubt, that the laterites of the IIawaian Islands owe their origin, on a grand scale, to the action of sulphurous steam in the disintegration of the lavas.

If we extend our observations, and associate them with phenomena that have been noted in other countries, it is indicated that our conchusions may be found to allow of a more universal application. Authorities have been used to obtain a view of the prevalence of past volcanic action over surfaces of the globe, and we know of the basalt and tufa eroptions of Europe and the British Isles: of the lavas of India and Africa; and by the recent work 


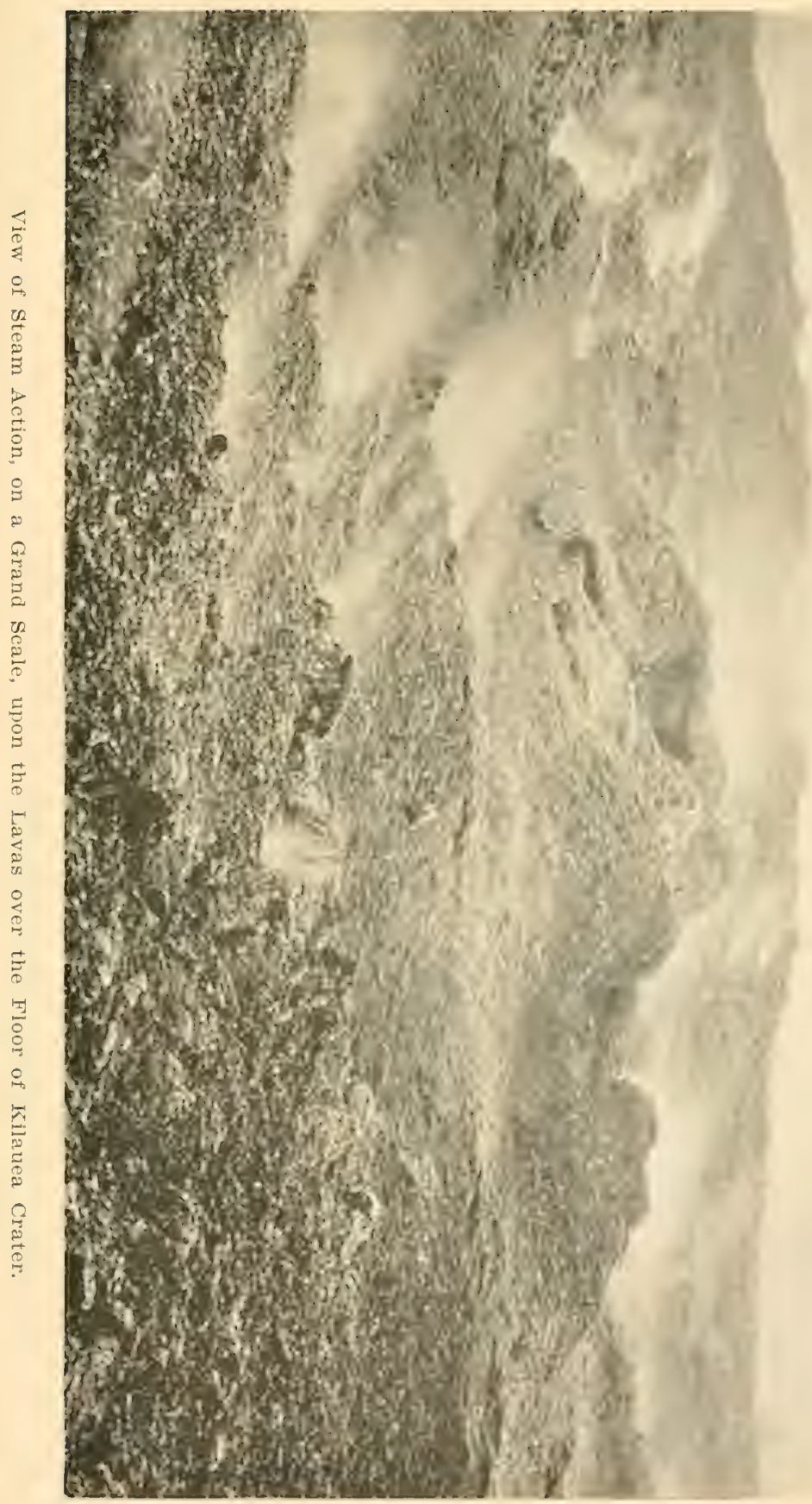



cf Russel, more of the magnificent areas of an earlier volcanic activity in the regious of Mexico and the Pacific Slopes. Further, we have noted the association of formations of "laterite" with locations of igneous rocks; Lyell having shown the relations of laterite and basalts in Eug. land and Scotland; Blaudford and Delesse the same conditions in India and other countries, and the "red ochres" of North-western America may be shown to have a rela. tion to the volcanic movements of those regions. Therefore the wide-spread appearance of these phenomena cause us to think that chemical causes may have exercised an enormous and wide-spread action in rock. disintegration, and whose results may be still found re. corded in the soils of the older continents and lands.

Weathering.--In previous paragraphs it has been in. dicated that large masses, and areas of lava surfaces, have suffered primary disintegration under the artion of chemical causes; and that other vast areas have not been acted upon by those special chemical agents. All lavas, however, whether they have, or have not been initially acted upon by chemical agencies, are resolved by the in. fluences of "simple weathering" into the palpable state in which they are called soils.

The several influences that are understood under the term "weathering" may be summarily expressed as variations in atmospheric heat and moisture. Great extremes of temperature act powerfully in the fracturing and disintegrating of rock masses where moisture is present. In tropical climates the extremes of tempera. ture do not obtain, but the continuous action of high temperature, combined with rainfall, upon rock surfaces leads to the same results; and when these combined in. 
fluences are aided by the growth and decay of a luxmiant vegetation, the final work of disintegration is rery rapid.

The appearance and chemical composition of decompos. ing lavas and their decomposition-products are affected by the degree of atmospheric heat and moisture. On the lee side of these islands, where the heat is more constant and intense, the air dry, and the rainfall almost nothing, the lavas undergo a slow, dry oxydation, and become a soft red or rich chocolate in color, due to the formation of non-hydrous oxide of iron. In locations where the moisture in the air is high, and the rainfall great, and sometimes enormous, the same lavas undergo a more decidedly hydrous oxydation, which gives to them a yellow, or yellow-brownish color, due to the hydration of the iron oxide. 'This effect compares, in a measure, with the results of oxydation under the action of steam upon the lavas, which, in the case of tufas, has been shown to produce colors of every hue and degree of vividness. 'These various results of weathering, under the action of different conditions of heat and moisture, will be further considered in connection with soils.

At the time that the writer collected specimens of the great masses of solid lavas upon the sereral islands, specimens were takeu of these same lavas that had been exposed to atmospheric action, and which represented states of disintegration under simple weathering. The condition of these weathering lavas is set forth by the following partial analyses. 
WEATHERING LAVAS.

\begin{tabular}{|c|c|c|c|c|c|c|}
\hline Noisture. & $\begin{array}{c}\text { Com- } \\
\text { bined } \\
\text { water. }\end{array}$ & $\mathrm{SiO}_{2}$ & $\mathrm{Fe} O$ & $\mathrm{Fe}_{2} \mathrm{O}_{3}$ & $\mathrm{Al}_{2} \mathrm{O}_{3}$ & $\mathrm{CaO}$ \\
\hline $\begin{array}{c}\text { Per cent. } \\
2.57 \\
3.26 \\
5.71 \\
3.94 \\
9.48 \\
9.25\end{array}$ & $\begin{array}{c}\text { Per cent. } \\
3.53 \\
12.71 \\
7.61 \\
3.23 \\
8.31 \\
10.40\end{array}$ & \begin{tabular}{|l} 
Per cent \\
43.19 \\
39.31 \\
36.38 \\
35.38 \\
30.24 \\
26.19
\end{tabular} & $\begin{array}{c}\text { Per cent } \\
540 \\
2.63 \\
3.75 \\
4.94 \\
845 \\
8.38\end{array}$ & $\begin{array}{c}\text { Per cent. } \\
9.90 \\
12.63 \\
15.81 \\
8.53 \\
8.38 \\
14.38\end{array}$ & \begin{tabular}{|c|} 
Per cent \\
23.47 \\
2508 \\
20.58 \\
16.58 \\
20.22 \\
25.18
\end{tabular} \mid & Per cent \\
\hline Mean. 570 & 7.63 & 3511 & 5.59 & 11.27 & 21.85 & 7.06 \\
\hline
\end{tabular}

The average composition of these weathering lavas we now bring into comparison, aspecially, with the hydrous solid lavas, with which they were originally identical, and with the tufas. The first line in the table is given to the non-hydrous solid lavas.

\begin{tabular}{|c|c|c|c|c|c|c|c|}
\hline Lavas. & $\begin{array}{c}\text { Mois- } \\
\text { ture }\end{array}$ & $\begin{array}{l}\text { Com- } \\
\text { bined } \\
\text { water }\end{array}$ & Si $\mathrm{O}_{2}$ & $\mathrm{FeO}$ & $\mathrm{Fe}_{2} \mathrm{O}_{3}$ & $\mathrm{Al}_{2} \mathrm{O}_{3}$ & $\mathrm{CaO}$ \\
\hline & \begin{tabular}{|}
$\mid$ Per \\
cent.
\end{tabular} & $\begin{array}{c}\text { Per } \\
\text { cent. }\end{array}$ & $\left|\begin{array}{c}\text { Per } \\
\text { cent. }\end{array}\right|$ & $\begin{array}{l}\text { Per } \\
\text { cent }\end{array}$ & $\begin{array}{l}\text { Per } \\
\text { cent }\end{array}$ & $\begin{array}{l}\text { Per } \\
\text { cent. }\end{array}$ & $\begin{array}{l}\text { Per } \\
\text { cent, }\end{array}$ \\
\hline 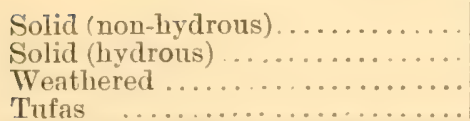 & $\begin{array}{l}0.41 \\
0.82 \\
5.70 \\
7.72\end{array}$ & $\left|\begin{array}{r}0.13 \\
1.96 \\
7.63 \\
11.49\end{array}\right|$ & $\begin{array}{l}49.12 \\
44.66 \\
35.11 \\
26.60\end{array}$ & $\begin{array}{l}8.43 \\
8.66 \\
5.59 \\
1.69\end{array}$ & $\begin{array}{r}4.04 \\
5.62 \\
11.27 \\
25.79\end{array} \mid$ & $\begin{array}{l}21.94 \\
1706 \\
21.85 \\
23.58\end{array} \mid$ & $\begin{array}{l}9.24 \\
8.23 \\
7.06 \\
1.41\end{array}$ \\
\hline
\end{tabular}

In the individual analyses, as well as in the averages, the signal differences between the tufas and the normally weathered lavas, are seen in the exhaustion of the lime, reduction of the alumina, and enormous increase of the iron in the former, as compared with the steady loss of lime and increase of iron and alumina in the latter. The action of sulphurous steam upon the tufas has already been explained as a cause of the rapid remoral of the lime, also of the alumina, from the laras. The removal 
of the silira, as the hydration of the lavas proceeds, will be spoken of in another place, and in comnection with the

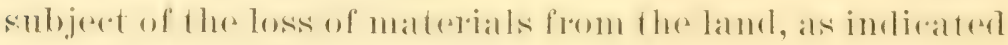
by the examination of waters of discharge.

In studying any given kind of rocks or lavas their characteristic features are brought out with a more im.

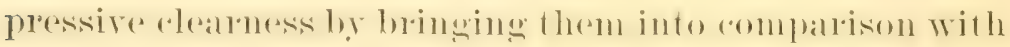
other classes of rocks. For this reason we shall give the chemical composition of various rocks which make up formations in North America, and from which the soils of those regions have been derived. For the composition of American rocks we are indebted to the incomparable collection of "Analyses of Rocks" by Messis. F. W. Clarke and W. F. Hillebrand, of the U. S. Geological Survey.

COMPOSITION OF AMERTCAN ROCKS.

\begin{tabular}{|c|c|c|c|c|c|c|c|c|}
\hline Rocks. & $\mathrm{SiO}_{2}$ & $\mathrm{Al}_{2} \mathrm{O}_{3}$ & ${ }_{3} \mathrm{Fe}_{2} \mathrm{O}_{3} \mid$ & Fe O & $\mathrm{CaO}$ & $\mathrm{MgO}$ & $\mathrm{K}_{2} \mathrm{O}$ & $\mathrm{Na}_{2} \mathrm{O}$ \\
\hline & $\begin{array}{l}\text { Per } \\
\text { cent }\end{array}$ & $\begin{array}{r}\text { Per } \\
\text { cent. }\end{array} \mid$ & $\begin{array}{c}\text { Per } \\
\text { cent. }\end{array}$ & $\begin{array}{l}\text { Per } \\
\text { cent. }\end{array}$ & $\begin{array}{l}\text { Per } \\
\text { cent. }\end{array}$ & $\begin{array}{l}\text { Per } \\
\text { cent. }\end{array}$ & $\begin{array}{l}\text { Per } \\
\text { cent }\end{array}$ & $\begin{array}{l}\text { Per } \\
\text { cent. }\end{array}$ \\
\hline Siliceous Sandstones. & 88.48 & 5.85 & 3.10 & 0.00 & 0.44 & 0.66 & 1.41 & 1.29 \\
\hline Granites........... & 72.50 & 14.40 & 2.14 & 0.00 & 1.76 & 052 & 4.58 & 3.33 \\
\hline Inoesin. . . & 17.76 & ; $11<!$ & $1+15$ & () 110 & 3.65 & 1.92 & 237 & 152 \\
\hline Clay stomes... & 57.00 & 24.50 & 1.05 & 0.00 & 318 & 165 & & \\
\hline Slates ind Shales. & 5136 & 15.54 & +4.14 & 3.85 & 1.82 & 3.20 & 2.81 & 1.73 \\
\hline Iron Carb-silicates . .... & 3600 & 1.22 & 2.52 & 26.45 & 4.44 & 4.43 & & \\
\hline Lime Carb-sulf-silicates & 4.42 & 0.32 & 20.30 & 0.00 & 50.65 & 2.28 & 0.40 & 0.30 \\
\hline an of Above & 53.93 & 1200 & & 81 & 9.42 & 210 & 2.31 & 1.67 \\
\hline ican Basalts & 49.15 & 15.66 & & .52 & 8.29 & 7.90 & 2.81 & 190 \\
\hline iian Basa & 47.90 & 18.23 & & & 8.99 & $6.05 \mid$ & 2.20 & 1.50 \\
\hline
\end{tabular}

Our immediate purpose in comparing the several classes of American locks with Hawaian lavas will be very presently seen in the discussion of Hawaiian soils.

There is a profound geological reason, howerer, for the comparison of these classes of rocks with basalts. If we 
refer back to the decomposition-ploflucts, which we have shown are severally formed from the risintegration of lavas, we are struck by the resemblance of these Hawaiian products, in chemical composition, to the respective kinds of American rocks. At this time we do no more than note this analogy, and shall reserve its discussion until the time when the whole subject matter of this study shall be considered at a later time in a work of greater scope and detail. 


\section{HAWAIIAN SOILS.}

Under the action of the several agents and modes of disintegration, it has been shown how that the lavas have become decomposed and resolved into earths. It is thus from the decomposition of the lavas that the soils of these islands have been derived.

It has been shown moreover, that in the course of dis. integration the lavas have riedede a series of ealths and products, each of which has been more or less separated from the others, and many of which have been removed from the place of their formation, and have gone to the laying down of other formations, either at lower levels on the land, or under the sea. Due to the small areas of these islands, and to the acute declinations from the mountains to the ocean, and also to heavy rains, especially on the windwated exposures, the sepallation-puroluets in the disintegration have been borne largely to the sea.

If the lavas, in the course of disintegration, have fallen into these several classes of decomposition products, many of which have been separated from the mass, and carried away, it then appears that the soils in place must bear only a remote relation to the rocks from which they have been devived. A comparison of the composition of the lavas, with the average of some six hundred soils derived from them, indicates that the relation is a very dis-

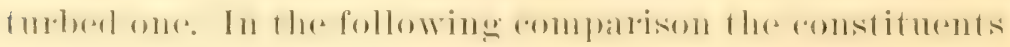


of the soil are calculated on the mineral matter, in order to note the extent of the alteration.

COMPOSITION OF HAWAIIAN LAVAS AND SOILS.

\begin{tabular}{|c|c|c|c|c|c|c|c|}
\hline Material. & Si O & $\begin{array}{c}\mathrm{FeO} \\
+ \\
\mathrm{Fe}_{2} \mathrm{O}_{3}\end{array}$ & $\mathrm{Al}_{2} \mathrm{O}_{3}$ & $\mathrm{Ca} \mathrm{O}$ & $\mathrm{Mg} O$ & $\mathrm{Na}_{2} \mathrm{O}$ & $\mathbf{K}_{2} \mathrm{O}$ \\
\hline & $\begin{array}{c}\text { Per } \\
\text { cent. }\end{array}$ & $\begin{array}{c}\text { Per } \\
\text { cent. }\end{array}$ & $\begin{array}{l}\text { Per } \\
\text { cent }\end{array}$ & $\begin{array}{l}\text { Per } \\
\text { cent. }\end{array}$ & $\begin{array}{c}\text { Per } \\
\text { cent. }\end{array}$ & $\begin{array}{l}\text { Per } \\
\text { cent }\end{array}$ & $\begin{array}{l}\text { Per } \\
\text { cent. }\end{array}$ \\
\hline Hawaiian Lavas & 47.90 & 13.36 & 18.23 & 8.99 & 6.05 & 2.20 & 1.50 \\
\hline Hawaiian Soils. & 27.51 & 36.45 & 22.64 & 0.46 & 1.07 & 1.19 & 0.62 \\
\hline
\end{tabular}

In general, the comparison shows that the silica, lime, magnesia, the alkalies, also much alumina have been borne away. Fortunately the life in the sea has gathered up much of the escaping lime, and restored it to us, at our very doors, in the form of coral reefs which begirt the islands. The full significance of the vast difference in the composition of the lavas and soils will be considered in detail at a later time, the present purpose being only to illustrate that these, and all other soils beal only a distant lolation to the rocks from which they have becen formed. Throe are formations aud soils which lepresent the separation mouduct.x, and ot her soils the rexidunl produrts of the lavas and rocks from whose disintegration they have been devired. We have to deal, in the main, with scils that are the residual products of disintegrated lavas.

Attention has already been called to the action of tem. perature and rainfall in the matter of weathering of rocks, and in the final disintegration of the materials forming soils. 'The variations in rainfall and the effects of less or greater precipitation, have been such as to advise the division of the soils into uplands and lowolands, the former representing the areas of larger, and the latter 
the areas of smaller rainfall. In later paragraphs tre shall discuss these evideners of the direet results of horal climatic conditions. Just now, we have to consider our soils from a point of view from which it may be seen that the great differences in their nature, and ecomomic value, are due to other causes, no less than to variations in climatic conditions.

The soils of these islands, and of of here conntres where the lands bear a resemblance to these, pass generally under the definition of red, or yellow soils. At first view this definition seems to be in place; but when we come to examine into the origin of the different reds and yellows, and note their chemical compositions, it is then foume that this general definition does not apply, ambl ma! actually conceal the most basic and vital differences. Morester, the definition is too definite, giving the impession, more or less, that all our land surfaces are either vivid reds or bright yellows, which is far from the case. The red soils vary in colors from dark reds to crimson and light resk, the latter usually being contiguous to, or foml within areas where soils that vary in color from light to reddish-yellow prevail. 'The dark, blood-red soils are frequently more distinctly marked off from those of other colors; but this is not, by any means, always so. Then, in addition to red and yellow soils we shall have to speak of certain dark soils, and of their origin and characteristics.

The common definition has been carried still further, and used to denote the qualities of the soils: In general, the red soils have come to be considered as from soils, and the yellow as poor soits. 'This also is far from being wholly roneret; although certain led soils are very fertile, and many yollow soils are sterile. Actual experience has 
shom men engaged in the island agriculture that whilst given areas of red land are rich, and permanent in fertility, there are other red soils in which, practically speak. ing, nothing will grow. This is actually the case, despite the general definition which has marked the red soils as good soils. Te have therefore, in the first plare, t' inquire into the causes of difference between the kinds of red soils, and into the enormous differences in their fertilit? and economic value?

Dark Red SoIls.-In the previous paragraphs, which were occupied by the examination of the several forms of lavas, the results and conclusions arriverl at were summed up as follows: "Anongst Hawaiian lavas are those which have discharesed from craters, flowing and rooling into rocks having the composition of normal basalts. Others, originaly of the same composition, have undergone such alteration that they now compose rocks masses having a radicalle rifferent chemical composition and color appearance. This alteration took place at the time of ejection, ancl undel the action of chemical causes, and previous to the later action of secondary causes of rock disintegration, such as 'weathering,' which has apparently been the onl agent of disintegration of certain of the normal lavas."

There are broad and defined areas, especially upon the Islands of Mauai, Oahu and Kanai, where the lava rlischarges from the great craters have flowed and cooled into rocks, and upon which simple weathering appears to have acted as the only influence in their disintegra. tion; and there are other more acutely marked areas where the lavas have undergone such alteration at the time of ejection that their appearance and composition are radically different from those of normal lavas. 
The areas which represent the flows of normal, umaltered lavas, whose surfaces appear to have become disintegrated by the slow action of simple weathering, are found, in the greatest part, upon the lee sides, or south exposures of the Islands; and consequently within the districts of smallest rainfall. This is far from being exchusively, although it is mainly so. It happens fur. ther, that whilst certain of these areas are not exposed strictly to the south, the rainfall, due to local topo. graphy, is nerertheless small. In distinction form what we have said is chiefly the rule, there are at least two small and indistinctly defined areas on Hawaii where it appears that the underlying lava has come down from the great craters by a free flow, and has been largely free from other causes of disintegration than weathering. Those areas liave a full windwated exposture, and lie moler, the one a very heary, and the other a medium rainfall.

The areas, that have been defined as representing discharges of more or less free flowing, normal lavas, which Iavas have undergone slow disintegration in hot expos. nes, with a minimum rainfall, are now the districts marked by the predominance of dark red soils. These districts are known as follows: Paia, and parts of Spreckelsville and Lahaina, on the Island of Mani. In these districts a high temperature with hot winds pre. vail, and a mean annual rainfall of about twenty inches. The upper district of Ewa, parts of Waianae and Waialua, on the Island of Oahu; where high temperatures prevail, and the rainfall does not exceed thirty inches. Waimea, Makaweli, and parts of the districts of Lihne and Kealia on the Tsland of Kamai. The districts of Waimea and Makaweli are distinguished by high temperatures and dry winds laden with clouds of red dust. In 
these districts the rainfall is also not more than thirty inches per annum. In Lihue the temperature is high, and the rainfall on the low, red lands small. It is not to be understood that no othel than "deep red soils" are found in these districts; but rather that these red soils predominate, and have cansed the districts to be distin. guished by their prevalence.

Generally, the "dark red soils," in the districts we have named, go down to a great depth. We have noted the cutting of water ditches to three and four feet deep; yet at the latter depth is found the same texture of soil, of the same deep, blood red color. In these soils no small rock fragments, or stones, are found, or very seldom; but large areas are more or less covered with decomposing lava blocks or boulders, some of which protrude through the surface of the lands, and others are concealed below. The soil, however, is formed to a depth below many of the lavas blocks, which are imbedded in it. In clearing large areas, in the districts mentioned, enormons cost has been incurred in removing these lava blocks that were in the way of deep cultivation, and pyramids of lava are seen stacked up in fields from which they have been collected.

We have spoken of these "dark red soils" as resting upon "areas of discharge of what were more or less free flowing, normal lavas." It is necessary to say, however, that the apparently great age of the lavas from which the dark red soils have been derived, and the advanced state of disintegration, make it difficult, and often im. possible to form any conclusion as to the mode in which those lavas discharged from the crater. The great "lava blocks or boulders," that have been describer as dis. tributed through and imbedded in the soil, sugerest that 
the flows may have been so-called "aa" of the roughest and most heaped-rip description, which contained, or in disintegration became resolved into, separate boulders. Or, as we see to-day at Kilanea, the lava may have flowed comparatively smoothly, and on cooling, contracted, and became broken up into blocks of small $o^{\circ}$ greater dimensions. This much, howerer, we are able to be sme of - that the lavas from which the dark red soils have been derived were normal, unaltered lavas; in acute distinction from the tufa lavas, the soils furnished by which will be discussed later. In proof of the maltered nature of these lavas at the time of discharge, the examination of the inside or kernels of the greater blocks imbedded in the soil, and which have had to be broken mp by blasting, and remored to permit of cultiration, has shown these to have the same compact texture, and the dark blue-glay color of unchanged lavas, and the chemical analyses state that they are normal basalts. Further, we are able to say that these lavas have undergone disintegration under the action of simple weather ins; and in climatic conditions characterized by almost uninterrupted sunlight of great intensity; a constantly hot and dry atmosphere, and an extremely small rainfall.

The deep soft red color of the soils under discussion has to be associated with the mode of oxydation of the iron constitnents of the laras. The nolmal laras contain the iron, in the greatest part, in the form of tark ferrous oxide. When this ferrous oxide is exposed to the agencies which cause disintegration it takes up a further quantity of oxygen, and goes over into ferric oxide. If the disinte. gration of the lavas containing much iron takes place in 
a moist atmosphere, or under great rainfall, or in the presence of steam, the ferrous iron not only takes up mole oxygen, but some water in combination with it. If, how. ever, the decomposition of the lavas is slow, and proceeds in a dry atmosphere, and at high temperature, the fer. rous iron can go gradually over into the ferric state by the taking up of oxygen from the air, with little or no water. These conditions go to determine what the color of the oxydized iron and that of the decomposed lava and soil in which the irom is present, shall be when the disintegration is complete. Where dry oxydation takes place, as in conditions of high temperature and no moist. mre, the color of the iron, and of the earth or soil that it colors, is red. If the oxydation takes place in the presence of moisture, and especially of excess of moisture, or steam, the color can rary from that of iron rust, through degrees of shade to actual yellow, which latter we find in our sub-soils under great rainfall, and in tufa masses where the iron has undergone oxydation saturat. ed with steam. The color of the oxydation products where excess of steam has operated depends however upon the temperature of the steam at the time of action. Dana and other geologists have observed that where "the temperature of the steam exceeds 200 degrees Fahrenheit the iron oxide may be red." In another place Dana remarks "under" exposure to air" and moisture, the ferrous oxide changes to brown or limonite yellow." 'Thus, and apparently due to the cause explained, the tufa masses, and tufa soils, may be either red or yellow, which depends upon the heat of the steam that acted on them at the time of ejection. In proof of this, it is found that all the yellow and brown tufas and soils instantly 
turn red when they are heated, and the combined water is driven otr.

It is thus indieated that the dark red soils have not only been deroived from normal, maltered laras, but they have been formed under phrsical conditions of heat and dreness that render the oxydized irou, and earths contain ing it, red. We have alreadr spoken of the dromess of the air, and the smallness of the rainfall orer the areas where the dark red soils prevail. 'The action also of the direct heat of the rentical sum rars is intense! We have taken the temperatures of the surfaces of bare lavas upon which the sum had been descending for sereral hours, and whilst the temperature of the air did not exceed s5 degrees, and mas often much less, the absorbed heat of the lavas was sreater than the hand could bear, and has been found to be over 160 degrees Fahreuheit. The opposite climatic conditions prevailing in other districts, where the moist. nre of the air and the rainfall are extreme, enable us to account for the bromn or rust color of the soils, and the light, rellow color of the sub-soils, eren where those soils are the weathered products of normal laras. We have mentioned two areas on the windward side of Ha. maii where the soils appear to have been derived from solid, maltered laras bx the action of weathering. The location of thinty-nine lateral ol tufa cones, howerer, upon the areas lring between Hilo and Kukuihaele in. dicate how uncertain it is to say where, and where not, special chemical action has primarily assisted in the disintegration of the laras, and which are soils formed by weathering, and which are derived from tufas? The two small areas indicated are fommd, the one in the neighborhood of l'epeekeo, and the other forming the deep, and generally more muiform, lands of Paauhau. 


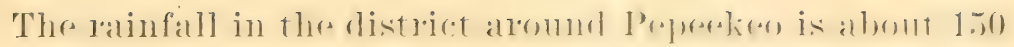
inches per year; and while the rainfall at Paauhau is now much less, there are evidences that the whole district of Hamakua, and also that of Kohala, exister under conditious of moisture and rainfall, during some former period, quite different to what obtain to-day. The Island

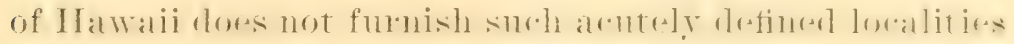
of normal lavas that hare been disintegrated br weather. ing, as distinguished from tufa lara areas, as are found on the other three islands; neither have its climatic conditions been such as to impart definite colors to the laras during their course of disintegration. Apart from the tufas, and the red and jellow or gras colored products of decomposition of the laras formed under special chemical causes, the decaying rocks, and the soils of Ha. waii are more generally of a rust color, which combines the yellow and a dullish red, each of these colors coming more or less to the front in some locations and soils. In locations where accumulations of organic matter in great abundance have decayed, the soils are darker, or almost black. Especially upon the upper lands, where the rainfall is the greatest, and the organic decas enormous, a rery dark soil may be found orerlying a subsoil which at a depth of two feet, is almost bright rellow, or a sellow tinted with spots of light red.

Learing the "dark red soils," and passing on to the "light red or crimson red soils," which are frequentlp confounded with the former, we have already remarked that the crimson and light red, on account of their origin and chemical composition, belong essentially to the class which includes the "rellow soils." For this reason rer? little attention has been giren to the light red soils, as they are not a type distinct in themselres. The follow. 
ing comparison of dark red soils with samples of light red soils indicates the great distinction in the relative amounts of the more prominent constituents, as shown by the agricultural analyses:

\begin{tabular}{|c|c|c|c|c|c|}
\hline Soils. & $\begin{array}{l}\text { Insolu- } \\
\text { ble Nlat- } \\
\text { ter. }\end{array}$ & $\begin{array}{l}\text { Com. } \\
\text { bustible } \\
\text { Matter. }\end{array}$ & $\mathrm{Fe}_{2} \mathrm{O}_{3}$ & $\mathrm{Al}_{2} \mathrm{O}_{3}$ & $\mathrm{CaO}$ \\
\hline & $\begin{array}{l}\text { Per } \\
\text { cent }\end{array}$ & $\begin{array}{l}\text { Per } \\
\text { cent. }\end{array}$ & $\begin{array}{l}\text { Per } \\
\text { cent. }\end{array}$ & $\begin{array}{l}\text { Per } \\
\text { cent }\end{array}$ & $\begin{array}{l}\text { Per } \\
\text { cent. }\end{array}$ \\
\hline $\begin{array}{l}\text { Dark Red Soils ............. } \\
\text { Light Red Soils ........... }\end{array}$ & $\begin{array}{l}37.202 \\
24.500\end{array}$ & $\begin{array}{l}11.330 \\
20.010\end{array}$ & $\begin{array}{l}22.94 \\
29.10\end{array}$ & $\begin{array}{l}16.8 . t \\
10.01\end{array}$ & $\begin{array}{l}0.34 .4 \\
0.150\end{array}$ \\
\hline
\end{tabular}

This comparison in average suggests that in the dark red, and light red soils we have to do with two distinct types. The relative fertility, and economic ralues of the two types will be set forth in another place.

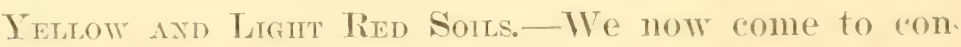
sider soils that appear to be derived from lavas which, although originally of the same character as the normal lavas from which the dark red soils were derived, underwent such alteration at the time of ejection, under the action of steam and acid vapors, that their appearance and chemical composition are radically different to that of the normal lavas, and which we largely explained under the head of "tufas."

It has been shown that lateral or "tufa cones" exist on all the islands; that tufa lavas are very generally distributerl; consequently, what may be called tufa snils are found composing large land areas. The circumstance that ejections of tufa lavas have marked the expiring activities of laree, as well as the chief action of the lateral craters, would cause a wide-spread prevalence of these altered lavas. Forming largely the latest ejections, 
and corering mp earlier floms of more solid lavas, they compose, orer large breadths of surface, the rock materials from which the soils have been derived.

Orer the four large islands, the districts that have been more especially marked by tufa cone action, and where tufa lavas, and yellow and light red soils are found, are parts of Hilo, Hamakua, and Kohala, on the Island of Hawaii; Makawao and Hamakuapoko, on the Island of Mani; Heeia, and parts of Honolulu, Pearl City, Waialua and Kahuliu, on the Island of Oahu. Parts of Lihne and Kealia, and Kilanea and Koloa on Kanai. Kilanea, Koloa, Heeia, Makatrao and some localities on Hawaii have been centers of the most violent tufa-lava production upon the Hawaiian Islands.

The colors and appearance of the tufa masses, we have already explained, pass from crimson red to the brightest yellow, every shade of lighter red, browns, and yellows being found between these extremes. Samples of dis. tinct red and of yellow tufas wele taken and examined in order to note whether the composition of the materials of different colors were analogous. In general, it was difficult to gain any instruction from a comparison of samples taken incidentally. The variations amongst the red on the one hand, and the jellow on the other, were as great as the rariations between the red and the jellow. The only mode of obtaining comparative data was by obtaining samples of red and yellow from blocks in close contiguity in the same tufa mass. In a fer instances only could this be done, but in these instances it was managed with great reliability. The samples, affording the analyses to be given, were taken from places not more than six feet apart. The lines of division betreen the red and yellow materials in place were acute and 
definite. 'Through the materials in block, marks of fissures, up which escaping steam had risen, are still visible. The composition of these tufas was found as follows-the arerages being given, and only of the constituents which form the chief mass of the materials.

\begin{tabular}{c|c|c|c|c|c}
\hline Lavas. & $\begin{array}{c}\text { Combined } \\
\text { Water. }\end{array}$ & $\mathrm{Si} \mathrm{O}_{2}$ & $\mathrm{Fe} \mathrm{O}$ & $\mathrm{Fe}_{2} \mathrm{O}_{3}$ & $\mathrm{Al}_{2} \mathrm{O}_{3}$ \\
\cline { 2 - 5 } & Per cen & Per cent. & Per cent. & Per cent. & Per cent. \\
Yellow Tufas .... & 10.60 & 3314 & 3.26 & 17.64 & 25.30 \\
Red Tufas. .... & 9.56 & 32.58 & 1.01 & 20.42 & 27.72 \\
\hline
\end{tabular}

It is seen that all the elements are found in about equal quantities in the two tufas. Noteworthy is the more adranced state of oxydation of the iron in the red material, through which, it is supposed, that steam of higher temperature has passed than passed through the yellow material. It is to the higher temperature of the steam that passed through the rock materials, according to the opinions of geologists already quoted, and our orril observations, that the color of the red tufas appears to be due. All the yellow tufas become red almost instantly when heated. That the color is not determined by the proportion of iron present in the tufas, or in the soils derived from them, appears from the fact that the amount of iron in the red tufas analysed raries between $11.85 \%$ and $26.3 \%$; and in the yellow tufas the variation is from $21.0 \%$ to $28.43 \%$. We have found one yellow material containing $49.11 \%$ of iron, and also some red materials containing above $60 \%$ of iron; but these were materials where the subsequent action of rain and air had cansed the removal of the constituents, leaving a ferruginous residne. The determination of the color ap. 
pears to be due, not to the amount of iron present, but rather to the form in which it is combined, and to the character of the physical comblitions, smelh as temperat me, at the time of emission of the tufa lavas. It is specially to be remarked that heat converts all the rariations of color into an unifor'm red.

The colors of the tufas pass on into the soils. Mounds and areas of tufa masses that were left a brilliant red at the expiration of the rolcanic activity have passed, and are passing into light red soils; and yellow soils result from the decay of yellow tufa masses. The masses of mixed colors have decomposed into soils in which definite shades are lost, and continued cultivation, and the results of erosion and rashing of heary rains, with the darkening action of regetation are assisting to oblit erate the original more definite colors. Before leaving the brief descriptions that have been made of the appearance, and apparent origins of "dark red soils," and of the "rellow and light red soils," we wish once more to guard against the conchusion that Hawaiian soils are all either distinctly red or yellow. We have endearored to bring into relief certain widespread and dominant types. There are large areas, howerer, that cannot be included by these types, and the particular phenomena of whose formation our accounts of probable origin of the red and rellow types do not necessarily cover. There are situations where the enormous rainfalls have made it difficult or impossible to trace the earlier causes of rock disintegration; which causes have assisted to determine the present character of the soils. But we are persuaded that these soils, whose origin and characteristics are not so definitely marked, come more or less within the two 
gleat classes that. we have rlescribed. 'l'his is indicated by theil location and chemical composition.

Nemdentare Solus.-In addition to the two types of soils which have been described as formed in place, there are considerable areas that owe their formation to wash and deposition. These areas are fommd mainly on the leeward side of the islands, and in districts of small rain. fall. 'T'he reposition is caused by heary gains falling in the mountains, carrying with them and distributing the materials of decomposing rocks over the lower levels. There are lamds, where crops are growiug to-rlar, that were formerly overflowed by the sea, which is indicated by the underlying coral formation. The rock debris bronght from the upper altitudes has laid down deposits over these low lands which vary from one foot to thirty feet in depth of soil. These soils are usually very fertile, which is due to the circumstance that only the finest of the decomposing rock materials, and materials that have been thoroughly acted mpon by the sum and air, and which are frequently mixed with organic matter, have been washed down. These soils bear the color of the decomposed rock material, frequently darened by organic matter.

'The districts where cultivatable areas of these deposited soils ale found are parts of Eva, Waianae, and Waimanalo, and pockets on Heeia and Kahuku,.on the Island of Oahu; parts of Spreckelsville, Wailuku, Olowalu, and Lahaina, on the Island of Mani; Mana, Kekaha, and pockets in IVaimea, Koloa, Lilnue, and Kealia, on the Island of Kanai. In addition to areas that are chiefly planted with sugar cane, in the districts named, these sedimentary soils are deposited at the outlets of each little valley, forming small deltas of highly fertile soils. 
The relative fertility and economic value of these soils will be compared with those of the other types of soil in a later place.

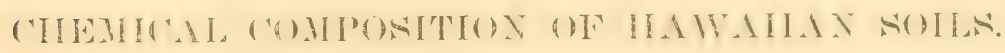

Following the descriptions that have been given, we shall present the results of the physical and chemical examinations of the "dark red soils," and of the "yellow and light red soils." As the sedimentary soils are not soils formed in place, but the result of wash, and of the indiscriminate removal and mixture of the two kinds of lavas which have respectively formed the dark red and light red and yellow soils, less attention has been given, so far, to their composition.

In the chemical examination, the mode of analysis is determined by the object or objects that are in view;- by the questions that the analytical data are required to explain.

If the purpose is an arbitrary one, and the data are required in order to compare the behaviour of one soil with that of some other soil, or of the soils of one type with those of some other type, under the action of some solvent that has been determined upon as a standard, then the usual agricultural analysis is enough, and adapted to that purpose.

If instead of, or in addition to, the information furnished by the agricultural analysis, and for geological reasons, we require to know the total mineral constitnents that compose a soil, and the relation of its compo. sition to the lavas or rocks from which it has been derived, then nothing short of an absolute analysis will do.

In these investigations, a leading purpose has been to 
trace the respective types of soils to their geological origins. 'This has been attempted by endeavoring to ascertain the nature and mode of discharge of the lavas, and the processes of disintegration by which the lavas have become resolved into soils. In order to complete the research, and to bring the original lavas and the re.

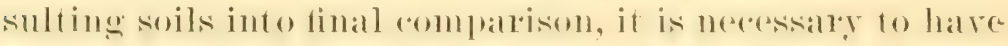
the total mineral compositions of the lavas and the soils. For this reason "absolute analyses" have been made of all the soils. Also "agricultural amalyses" have been made of the same soils, to furnish the value of a comparison of Hawaiian soils with those of other comntries.

'Therefore, the "chemical examination" embraces: (1) The "agricultural analysis," or the estimation of the amonut and constituents of the soil brought into solution by the action of hydrochloric acid, of $1.115 \mathrm{sp} . \mathrm{gr}$., for a period of 10 hours digestion on a water bath.

(2) 'The analysis of the insoluble residue of the soil, found insoluble by the "agicultural analysis."

(3) The "absolute analysis" of the soil free from water, but including combustible matter.

(4) The "absolute analysis," calculated on the soil free from water and "combustible matter."

The statement of results gives only the arerage com. positions of the "dark red soils," and of the "Yellow and light red soils." The average for each type embraces 10 type somples, and 120 sub-samples, and represents all the great areas covered by the respective types of soils. The actual number of aualyses made is much greater than is included in this statement, the agricultural analyses embracing over 1300 sub-samples; but these averages are based upon soils only which are very definitely representative of the respective types. 'To give the 
analysis of each individual sample would take up an un. necessary space, and would not bear on the present pur. pose. The individual analyses are for use in advising in the matter of fertilization on the several plantations.

\section{DARK RED SOILS.}

\begin{tabular}{|c|c|c|c|c|}
\hline \multirow[b]{3}{*}{ 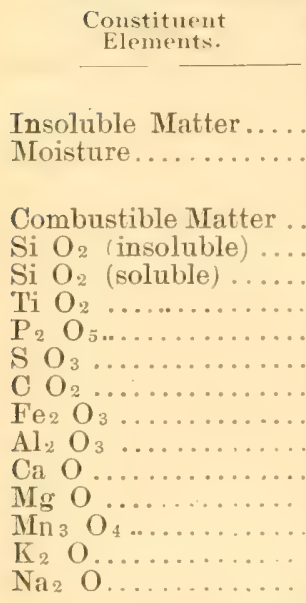 } & \multirow{2}{*}{\begin{tabular}{|} 
Acrricultural \\
Auilysis. \\
Ier cent. \\
37.202 \\
6.160
\end{tabular}} & \multirow{2}{*}{$\begin{array}{l}\begin{array}{c}\text { Insoluble } \\
\text { Residue }\end{array} \\
\text { Insoluble } \\
\text { In H Cl. }\end{array}$} & \multicolumn{2}{|c|}{ Alosolute Analysis. } \\
\hline & & & $\begin{array}{l}\text { Water-free } \\
\text { Soil. }\end{array}$ & $\begin{array}{l}\text { Mineral } \\
\text { Matter. }\end{array}$ \\
\hline & $\begin{array}{r}2.589 \\
0.193 \\
0.310 \\
0.180 \\
22.942 \\
16.838 \\
0.344 \\
0.437 \\
0.420 \\
0.386 \\
0.752\end{array}$ & $\begin{array}{c}25390 \\
43.460 \\
10.140 \\
0.310\end{array}$ & $\begin{array}{c}\text { Per cent. } \\
12.156 \\
10.06 \pm \\
17.606 \\
6.711 \\
0.322 \\
0.332 \\
0.193 \\
26.212 \\
23.717 \\
0.500 \\
0.659 \\
0.277 \\
0.512 \\
1.139\end{array}$ & $\begin{array}{r}29.784 \\
26.944 \\
0.568 \\
0.748 \\
0.314 \\
0.581 \\
1.300\end{array}$ \\
\hline & 100.083 & 99.480 & 100.400 & 100.057 \\
\hline
\end{tabular}

Acidic Constituents of the Soils ......... $=39.818$ Per cent.

Basic Constituents of the Soils......... $=60.237$

Total Nitrogen in the Soils ........... "6

Soluble in 3 per cent $\mathrm{K} \mathrm{O} \mathrm{H}$, in 30 hours $=\overline{0.106}$ "

Insoluble " " " " 3 "

Water Absorptive Power of the Soils . ...... " 
YELLOW AND LIGH'I 1RED SOILS.

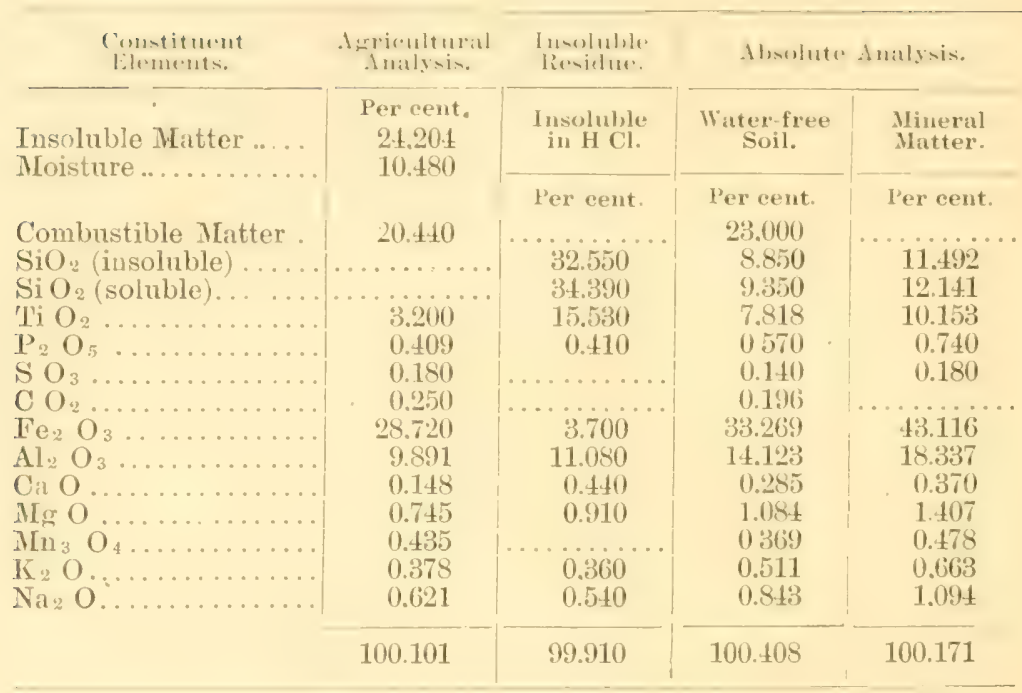

Acidic Constituents of the Soils ..... $=34.706$ Per cent.

Basic Constituents of the Soils . . .... $=05.465$

Total Nitrogen in the Soils ......... $=0.459$

Soluble in 3 per cent $\mathrm{KO} \mathrm{H}$, in 30 hours $=0.360$

Insoluble " " "

Water Absorptive Power of the Soils. . $=77.000$ "

The determinations of "absorptive power" were made with the "fine earth," which comprised $8.3 \%$ of the total soil.

Whaterer may have been the cause or causes of the difference, the relative compositions of the "dark red" and the "yellow and light red" indicate that we are dealing with extremely different types of soils.

After allowing for the higher amounts of moisture and combustible matter in the yellow soils, it remains notice. able that these soils contain a smaller proportion of con. stituents than the dark red soils that is not brought into solution by the hydrochloric acid. The yellow and 
light red soils are distinctly more soluble than the dark red soils. This also appears in fusing the soils to preplate for the absolute analysis. The light colored soils fuse more readily than the dark red ones. The relative amounts of "moisture" and "combustible matter" in the two types will be noticed more in detail in connection with considerations on the effects of climatic conditions.

Proceeding now upon the basis of the data giving the "mineral matter" by absolute analysis, it is seen that the total silica in the dark red soils is $33 \%$ greater than in the yellow and light red soils. Moreover the soluble silica is almost double that of the insoluble silica in dark red soils, whilst in the yellow soils the soluble and inso. Inble silicas are nearly the same. Tre beliere that the climatic conditions have accounted for some part of this great difference; yet the comparison of "upland," or soils under heary rainfall, and "low land," or soils under small rainfall, with the "dark red soils" and "yellow soils" indicates that the great difference in the matter of silica is a structural difference in the two types.

\begin{tabular}{|c|c|c|}
\hline Soils. & Insoluble Silica. & Soluble Silica. \\
\hline $\begin{array}{l}\text { Dark Red Soils.......... } \\
\text { Yellow and Light Red..... } \\
\text { Upland Soils } \ldots . \\
\text { Lowland Soils . . . . . . . . }\end{array}$ & $\begin{array}{l}\text { Per cent. } \\
11.449 \\
11.492 \\
14.568 \\
13569\end{array}$ & $\begin{array}{l}\text { Per cent. } \\
20000 \\
12.141 \\
14.450 \\
16.099\end{array}$ \\
\hline
\end{tabular}

The full data giving the composition of the "upland" and "low land" soils will be produced later.

The comparisons in this table enable us to estimate how much climatic conditions have caused the difference in the content of silica, and.in its state of solubility, and how much may be due to differences in structural compo. 
sition of the two types of soils. In viewing the relative amounts of "soluble" and "insoluble" silica, it is important to note the actually insoluble chatadedere of the lat lexe When the "insoluble residnes" Werere ligested with a fresh

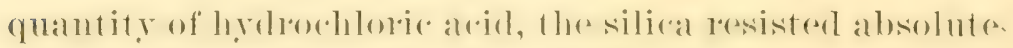
ly any further action of the acid, no more going into solution. Even after the removal of the soluble silica from the insoluble residues, further digestion with the acid had hardly an appreciable action.

The titanic acid is enormous in both types (the mear titanic acid in 10 lavas was $3.5 \%$ ). Its increase in each soil is strictly proportional to the decrease in the amount of silica. In the "dark red soils" there is $7.625 \%$ of titanic acid to $31.45 \%$ of silica. If we consider this amount as reduced to the proportion present in the "yellow and light red soils," which is $23.6 \%$, then the titanic acil to $31.45 \%$ of silica. If we consider this latter soils. These data not only show the insoluble nature of the titanic acid, they also furnish a furthe* indication that all the lavas, in their original state, were similar in composition, and that the difference in composition of the tufas or altered lavas, from which the yellow and light red soils have largely been derived, was caused at the time of, or after, their emission from the craters. These observations upon the titanic acis are made for the reason that it is the behaviour of the least. soluble constituents that we have to specially note in the endearor to trace a soil back to the rock from which it was derived, and to judge of the primary identity of rocks ol lavas from which different soils have come. Titanic acid appears to be the most insoluble constituent in Hawaiian soils. 
Coming to the relative amounts of iron and alumina in the two types of soils, we note a difference which is enormous, and extremely significant. Next to the silica, the iron and alumina are the cardinal constituents of the normal lavas; and their behaviour during the course of disintegration, with their relative proportions ultimately found in the soils, are data which furnish the most refinite instruction. In the "dark red soils" the iron oxide is $29.784 \%$; in the "yellow and light red soils" it is $43.116 \%$, an actual difference of $44.7 \%$. In the mat. ter of the alumina we find as significant a difference, but in the opposite direction. The dark red soils contain $26.944 \%$, and the light soils $18.337 \%$, an actual difference of $47.0 \%$. Before discussing the differences in composition of the two types of soils further, it will be well to bring the compositions of the soils into comparison with the analyses of the lavas from which, we have explained, the dark red, and yellow and light red, soils are respec. tively derived. In these comparisons are given only the more dominant constituents-silica, iron, alumina, and lime, and these are presented on the basis of mineral matter, free from moisture and combustible matter.

COMPARISON OF LAVAS AND SOILS.

\begin{tabular}{|c|c|c|c|c|}
\hline Materials. & $\mathrm{Si} \mathrm{O}_{2}$ & $\mathrm{Fe}_{2} \mathrm{O}_{3}$ & $\mid \mathrm{Al}_{2} \mathrm{O}_{3}$ & Ca 0 \\
\hline & $\begin{array}{c}\text { Per } \\
\text { cent. }\end{array}$ & $\begin{array}{l}\text { Per } \\
\text { cent. }\end{array}$ & $\begin{array}{c}\text { Per } \\
\text { cent. }\end{array}$ & $\begin{array}{c}\text { Per } \\
\text { cent. }\end{array}$ \\
\hline 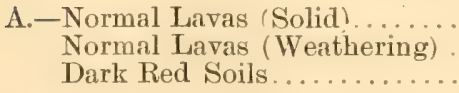 & $\begin{array}{l}47.59 \\
40.35 \\
31.45\end{array}$ & $\begin{array}{l}15.02 \\
20.52 \\
29.78\end{array}$ & $\begin{array}{l}19.92 \\
25.23 \\
26.94\end{array}$ & $\begin{array}{l}8.88 \\
8.11 \\
0.57\end{array}$ \\
\hline B.-Tufa Lavas $\begin{array}{l}\text { Yellow and Light Red Soils. } \\
\text {. }\end{array}$ & $\mid \begin{array}{l}32.84 \\
23.63\end{array}$ & $\begin{array}{l}33.92 \\
43.11\end{array}$ & $\begin{array}{l}29.11 \\
18.33\end{array}$ & $\begin{array}{l}1.74 \\
0.37\end{array}$ \\
\hline
\end{tabular}


In the passing over of the solid normal lavas, through the state of "weathering," into the dark red soils, is noted a most gradual change in the relations of the elements to each other. In the weathered specimens the relation of iron and alumina to each other is the same as in the solid lavas; and although the alumina has been, in part, removed and the iron has accumulated, in the course of the final resolution of the lavas into soils, the relation of the two chief constituent elements has been, visibly maintained.

In the tufa lavas it is seen that a most riolent dis. turbance of the relations of the elements was effected, and largely before the action of weathering began. As these latras passed finally into soils, the resation between the iron and alumina underwent a change that completely reversed the quantitative proportions of those elements as they existed in the original laras. This change has also removed the ground of comparison, and rendered the yelow and light red soils extremely dissimila in textme, color, and composition to the dark red soils derived from the normal lavas. We do not lay great stress upon the differences in lime and other soluble elements between the two types of soils, since climatic conditions, to which we shall presently refer, have had a great determining bearing upon the proportions of those elements left in the soils. It has been found, howerer, that in instances where yellow and dark red soils have been formed near together, and the rainfall essentially the same, the dark red contain, uniformly, more than double the amount of lime found in the yellow soils, and it was also found that in the yellow soils the largest proportion of the lime was contained in siliceons combinations in the "in. 
soluble residue," and only recorded by the "absolute analysis."

We have, in previous paragraphs, dwelt upon the sulphuric acid as an indicator of the mode of disintegration, and of the formation of soils. Like lime and the alkalies, this acid is readily removed by rain when in combination with the bases named, and is thus found in least quantity where the rainfall is the greatest. The upland soils contain $0.166 \%$, and the lowlands $0.210 \%$, of sulphuric acid. The "dark red soils," which have been formed in dry conditions, contain $0.332 \%$, and the "rellow and light red soils" $0.140 \%$ of sulphuric acid. If we leave the general averages, and note the variations in sulphuric acid in some soils of the same locality, where the rainfall is the same, a new set of indications present themselves. In the following data is found the measure of variation in the soils of localities, where the variation cannot be due to superficial causes such as rainfall.

\begin{tabular}{|c|c|c|}
\hline Localities. & Minimum $\mathrm{SO}_{3}$ in Soil & Maximum $\mathrm{SO}_{3}$ in Soil \\
\hline 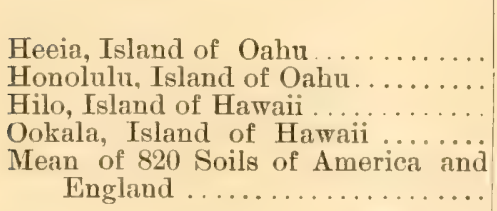 & $\begin{array}{l}\text { Per cent. } \\
0.050 \\
0.050 \\
0.210 \\
0.120 \\
\quad 0.04 \mathrm{P}\end{array}$ & $\begin{array}{l}\text { Per cent. } \\
0.828 \\
0.650 \\
1.290 \\
0.450\end{array}$ \\
\hline
\end{tabular}

In the cases where a high content of sulphuric acid has been found, it appears largely in combination with fer. rous iron, causing conditions inimical to plant growth, which we shall speak of again. These high amounts of sulphuric arid have, so far, only been found in soils where great rolcanic activity, and special rapor action on the 
lavas, have transpired. The small amounts of the acid found in soils within the same locality, and not half a mile apart, is to be accounted for, we believe, by the circumstance that we have alrearly explained, viz:"there are areas, contiguous to such as have been acted upon by sulphurous steam, where no traces of steam action are evident."

"Porsoned Spots." - In addition to the typical differences in the soils, which have been traced to the different lavas from which they have been derived, there are yet other variations. Within broad areas where the soils have beren derived from solid rocks by weathering, places or patches are found which appear, and behare quite differently from the smrombling land. Fardly anything will grow on some of these patches, and they are called "poisoned spots." In some districts upon an area of

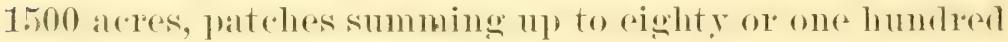
acres may be found. We are persuaded that these poisoned spots were caused by the action of sulphurous steam upon the solid lavas after their emission from the crater. We are led to this view by what is observed to day at Kilanea over the area of the crater floor, and which we have described in earlier paragraphs. At the active crater we noticed the action of the acid steam in changing the appearance and composition of the lava. We also noticed an accumulation of sulphuric acid in the altered lava, it having increased to three times the amount found in the lava where no steam action was proceeding. In comparison, these "poisoned spots" in the fields present a color appearance which not only causes them to resemble the steamed patches on the rater floor, but distinguishes them from the land arount. The poisoned spots are most numerous in districts on 
Hawaii, but they are also found on all the islands. On Kanai, in the district of Makaweli, the superb breadths of "deep red soil" are spotted with these patches, which are yellow to light red in color, and from one-half of an acre to more in dimension. Near to the old crater, which is now used as a large reservoir, these yellow colored spots are very acutely defined. Samples of the soil were taken from three of these poisoned spots, two from Hawaii, and one from Oahu, in each one of which the sulphuric acid was above $1.0 \%$, and the average of the acid in the three soils was $1.33 \%$. These data leave us almost without doubt that in the origin of those "poisoned spots" sulphurous steam was one of the potent factors.

We now present an example of a soil, of a gray-yellow color, in which the cause of color is not so evident as is the case with the yellow and light red soils generally. At Makaweli there is a breadth of land known as the "yellow ridge" which runs through a broad area of dark red soil, but is most acutely defined from the latter. This "yellow ridge" is a narrow strip running down through the main area of dark red soils which distinguish the locality. The lava which formed the yellow ridge was a later and distinct flow, but it came from the crater from whence the lavas forming the dark red soils came. Samples of the lava, in a state of weathering, which is forming the dark red soil, and also of the lava forming the yellow soil, were taken. The one lava, on its weathered surfaces, is already deep red; the other lava a dull rellow. The analyses of these two lavas gave as follows: 


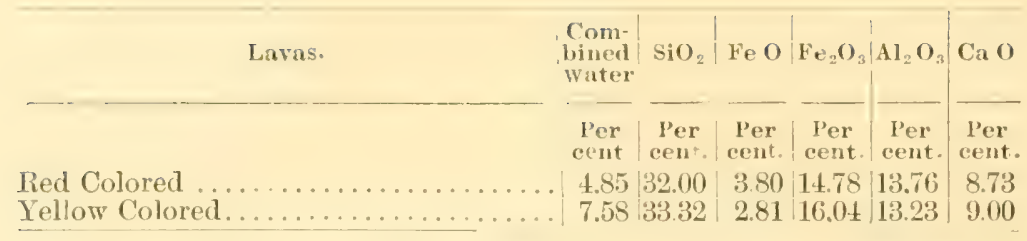

We have said that these lavas "were from the same crater," and the analyses say that, in chemical compo. sition, they are intrinsically identical. Yet the one is red and the other yellow! We note that the yellow contains nearly double the amount of combined water, and its iron is more adranced in oxydation, than is the case with the red lava, which is older than the yellow lava. These are the only marks of difference; but they are the peculiar marks of difference that would result from the action of steam at the time of, or after ejection. That steam acted upon the lavas after emission in this locality is shown by the "poisoned spots" in the red soils near by. But there is no excess of sulphuric acid in the yellow lava, or its soil, to indicate the past action of sulphurous steam. We remember, however, that at the Kilauea. crater, at this time, neutral steam is escaping through the lavas, and that in places where the steam was acidic two years ago, it is neutral to-day. These memoranda cause us to think that the yellow ridge lava, and consequently the soil, owe their color to the action of neutral steam at the time of, or after ejection, and that the practically un-altered state of the yellow lava may be due to the absence of sulphuric acid in the steam. The soils from these lavas are as follows: 


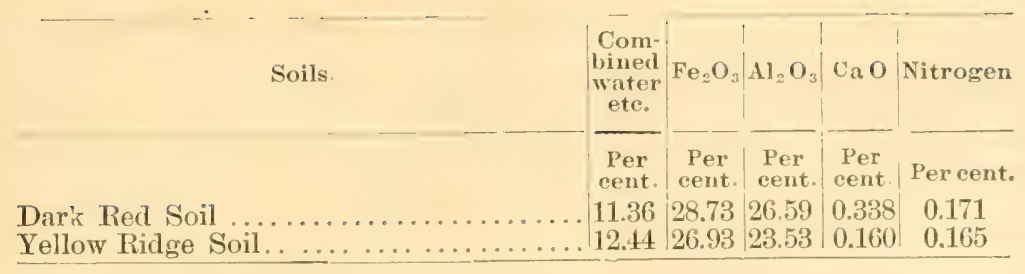

The relations of the iron and alumina indicate a ten. dency in change resembling the differences between the red and yellow soils in general. The lime points dis. tinctly in that direction. The larger amount of water of combination in the yellow soil corresponds with what was found in the lava; and the nitrogen content indicates that the excess of combined water in the yellow soil is in the form of mineral hydrates, and does not come from any excess of humus or organic matter, an indication which is supported by the exact sameness of the rainfall under which the dark red and yellow soils, in this example, were formed. This example is given in order that it shall be understood that there are instances of yellow soils whose origin and causes of formation are not yet fully understood; and which, with our present knowledge, we cannot safely include within any type that has been established.

\section{UPLAND AND LOWLAND SOILS.}

So far, the soils have been considered from the standpoint of the lavas, and of the processes of disintegration, by which these have been resolved into the materials which form the mineral constituents of soils; and as a result of the great differences in the soils, due to dissimilar causes of disintegration, they have been considered under several more or less definite types. 
Soils, however, are not merely decomposed rocks: 'They possess the elements which constitute the lavas, but they contain something more. We have seen that Hawaiian soils hold as high as 20 per cent. of "combustible matter," and while some soils have less, others contain more than this amount. 'This combustible mat. ter consists, in part, of simple water that has combined with the elements of the lavas, in the course of disin. tegration, and is driven off by heat. A large part, how. ever, is regetable matter, and oranic substances that result from vegetable decay. These vegetable materials, as our studies of the lavas have shown, are not found in essential rocks, and the elements that form these materials are seldom found in rocks, excepting such as are of organic origin. Carbon, nitrogen, hydrogen and oxygen are the elements which bear the burthen of all regetable structure. Carbon and nitrogen were primarily derived from the air, as they are being obtained from that sphere to-day. Hydrogen and oxygen, in addition to taking part as individual elements in the structure of plants, combined in the form of water they not only assist in conveying other elements from the air to the soil, but, as water, they are absolutely essential to the life and growth of plants, and out of all proportion to the actual amounts that take part in plant structure. Scientists have already shown how many tons of water have to be absorbed and evaporated in order to produce one ton of wheat, barley, oats, etc.; and we have just determined the weight of water used by the sugar cane, during a period of several months, in the making of one pound of its own substance, and that weight is enormous? These examples are not necessary however, to prove what is said: We need merely consider the queat 
deserts, on the one hand, and on the other, the vast areas of regetable luxuriance over the face of the earth, and it is at once apparent that vegetation and rainfall are concomitant conditions.

As the combustible organic matter in soils results from regetable decay, and the amount of regetation is proportional to the rainfall, it then appeas that humid soils, or those formed under great rainfall, should contain more organic matter than soils formed in arid con. ditions, and under a minimum rainfall. Further, as nitrogen is a constant, and only slightly variable factor in the organic matter, the nitrogen content of soils in legions of great rainfall should be miformly higher than in the soils of dry districts. On the other hand, and in acute distinction from the element nitrogen, which is brought to the soil as a direct and indirect result of rain. fall, the several mineral elements of the soil, such as silica, alumina, lime, etc., which were originally there, and which can be taken away by water, are liable to be the lowest where the rainfall is the greatest, and the highest where precipitation is least.

In view of these considerations, the agricultural analyses of our soils during the past three years were resolved into the two classes- "upland" and "lowland" soils. These analyses have covered something over 1,300 subsamples, in the most of which only the lime, potash, phosphoric arid, and nitrogen were determined. In all cases the samples were taken personally by the writer, or in fields, and by methods, stated by him. By "lowlands" is meant the land areas which run from the sea to an elevation of about 500 feet, and by "upland," the upper cultivated areas, which rise to about 1,500 feet. The application of these terms, homerer, is controlled by the dis. 
trict: For example, in parts of Hamakna the lowlands commence upon blufts that stand 200 feet or more abore the sea; whilst in Hilo the rainfall is so great at the sealevel that a division into "Iplands" and "lowlands," based on rainfall, camnot obtain.

We now give a brief smmmary of our findings during the past three years, which have ahready been discussed and published in some detail. The data represent the "lowlands" and "uplands" of Oahu, Maui, parts of Ha. Waii, and Kanai, and distinguish more or less acutely between areas of small and greater rainfall.

\begin{tabular}{|c|c|c|c|c|}
\hline Soils. & Lime. & Potash. & $\begin{array}{l}\text { Phosphoric } \\
\text { Acid. }\end{array}$ & Nitrogen. \\
\hline 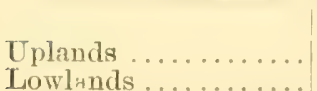 & $\begin{array}{c}\text { Per cent. } \\
0.331 \\
0.471\end{array}$ & $\begin{array}{c}\text { Per cent } \\
0.297 \\
0.328\end{array}$ & $\begin{array}{c}\text { Per cent. } \\
0.238 \\
0.213\end{array}$ & $\begin{array}{c}\text { Per cent. } \\
0.465 \\
0195\end{array}$ \\
\hline
\end{tabular}

These data represent the average of virgin and crop. ped soils on the "upland" and "lowland" areas. The lime contents in the respective soils support, without ang question, the original hypothesis "that the lime, etc., would be liable to be the lowest where the rainfall was the greatest." In the matter of organic matter and nitrogen our findings are still more emphatic in pronouncing that "regetation, nitrogen and rainfall are concomitant conditions." We can go one step farther for illustration of this relation of the nitrogen content of the soil to the rainfall: Upon all the four Islands most enterprising efforts are being made to extend the coffee production. The lands suited to coffee growth are at the elevation where it ceases to be profitable to grow sugar, or from 1000 to 2000 feet above the sea level. We have analyzed soils from some of these lands, and have 
obtained analyses made by other chemists, covering the coffee districts on Hawaii, and prospective colfee lands on Maui. The nitrogen in these thirteen coffee soils we compare with the nitrogen contents of the cane lands.

\begin{tabular}{|c|c|c|c|}
\hline Soils & $\begin{array}{c}\text { Approximate } \\
\text { Mean } \\
\text { Elevation. }\end{array}$ & $\begin{array}{c}\text { Approximate } \\
\text { Mean } \\
\text { Rainfall. }\end{array}$ & Nitrogen in Soil \\
\hline $\begin{array}{l}\text { Lowland Caue Soils... ... } \\
\text { Upland Cane Soils ...... } \\
\text { Coffee Soils............ }\end{array}$ & $\begin{array}{r}\text { Feet } \\
300 \\
900 \\
1,800\end{array}$ & $\begin{array}{c}\text { Inches } \\
50 \\
90 \\
130\end{array}$ & $\begin{array}{c}\text { Per cent. } \\
0.195 \\
0.465 \\
1.237\end{array}$ \\
\hline
\end{tabular}

We are indebted to the Government records for the "approximate mean rainfalls," and to our own observations in given districts. In one of the districts on Maui, a series of rain gauges placed at intervals up the moun. tain side, from 200 feet to 3000 feet, gave an annual rainfall of 28 inches at 200 feet elevation; 60 inches at 900 feet; and 179 inches at 2800 feet. In the Numani valley, Oahu, the rainfall at sea level is near 30 inches, and at 900 feet it is 118 inches.

On account of given questions and difficulties bearing mpon the maintenance of fertility of the upland soils, as compared with the lowland soils, a very exhaustive series of experiments was undertaken in order to try to obtain precise data concerning the "availability of the elements of plant food in the upland and lowland soils," the results of which will be set forth in the second part of this publication. The soils used in these experiments were, in the first place, subjected to exhaustive analysis in order to be able to note to what extent any differences in be. haviour of the upland and lowland soils, under the action of solvents used, would appear to be due to fundamental or structural differences in their composition. These 
analyses we introduce at this place on account of their special bearing also upon the question of the relation of rainfall to the organic matter and nitrogen content of soils. The analyses include and represent the average of nime type samples aud 108 sub-samples of upland soils, and of the same number of type and sub-samples of lowland soils. As already remarked, the samples were either taken by the writer, or under his direct instructions. Districts of the four islands are embraced, and the "limatir eomelitions and leneth of time that the lands hatre been under cultivation, have been carefully recorded. The results of the analyses are as follows:

\section{LOWLAND SOILS.}

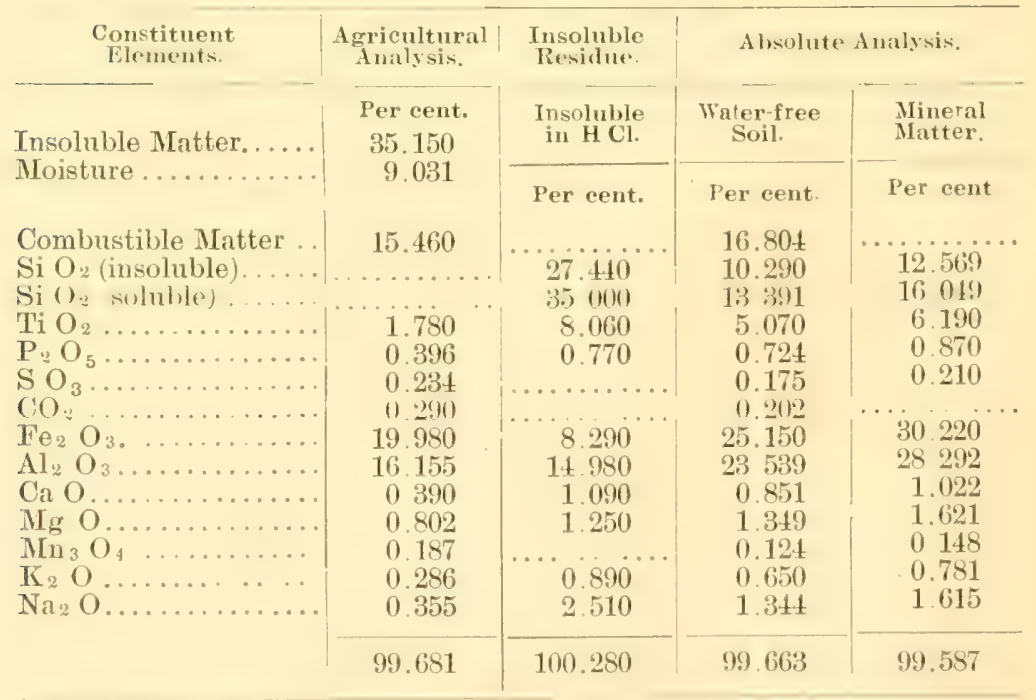

Acidic Elements in the Soils........ $=35.888$ Per cent Basic ". "6 . . Total Nitrogen in the Soils............ Soluble in 3 per cent $\mathrm{K} \mathrm{O} \mathrm{H}$, in 30 hours $=\overline{0.20 t}$ " Insoluble " " " 
UPLAND SOILS.

\begin{tabular}{|c|c|c|c|c|}
\hline $\begin{array}{l}\text { Constituest } \\
\text { Elements. }\end{array}$ & $\begin{array}{l}\text { Agricuitural } \\
\text { Analysis. }\end{array}$ & $\begin{array}{l}\text { Insoluble } \\
\text { Residue. }\end{array}$ & \multicolumn{2}{|c|}{ Absolute Analysis. } \\
\hline \multirow{2}{*}{$\begin{array}{l}\text { Insoluble Matter ..... } \\
\text { Moisture ........... }\end{array}$} & \multirow{2}{*}{$\begin{array}{c}\text { Per cent. } \\
27.870 \\
12.290\end{array}$} & $\begin{array}{l}\text { Insoluble } \\
\text { in } \mathrm{HCl} \text {. }\end{array}$ & $\begin{array}{l}\text { Water-free } \\
\text { Soil. }\end{array}$ & $\begin{array}{l}\text { Mineral } \\
\text { Matter. }\end{array}$ \\
\hline & & Per cent. & Per cent. & Per cent. \\
\hline $\begin{array}{l}\text { Combustible Matter . } \\
\mathrm{SiO}_{2} \text { (insoluble) ..... }\end{array}$ & 20.600 & 33.450 & $\begin{array}{l}23.300 \\
10.674\end{array}$ & 14.068 \\
\hline $\mathrm{Si} \mathrm{O}_{2}$ (soluble) $\ldots .$. & & 31.230 & 9.903 & $13.0 \pm 2$ \\
\hline $\mathrm{Ti} \mathrm{O}_{2} \ldots \ldots \ldots \ldots \ldots$ & 1.840 & 9.630 & 5192 & 6.739 \\
\hline $\mathbf{P}_{2} \mathrm{O}_{5} \ldots \ldots \ldots \ldots \ldots$ & 0.470 & 1.050 & 0.869 & 1.132 \\
\hline $\begin{array}{l}\mathrm{S}_{\mathrm{O}_{3}} \ldots \ldots \ldots \ldots \ldots \\
\mathrm{C} \mathrm{O}_{2} \ldots \ldots \ldots \ldots\end{array}$ & $\begin{array}{ll}0 & 157 \\
0 & 0: 30\end{array}$ & 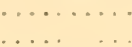 & 0.128 & 0.166 \\
\hline $\mathrm{Fe}_{2} \mathrm{O}_{3} \ldots \ldots \ldots \ldots$ & $\begin{array}{r}00.30 \\
21.810\end{array}$ & 3740 & 26.174 & 34.120 \\
\hline $\mathrm{Al}_{2} \mathrm{O}_{3}, \ldots \ldots \ldots \ldots \ldots$ & 13.621 & 14640 & 20.059 & 26.152 \\
\hline Сa $0 . \ldots \ldots \ldots \ldots$ & 0.294 & 0.950 & 0640 & 0.834 \\
\hline $\operatorname{Mg} O \ldots \ldots \ldots \ldots \ldots$ & 0.610 & 0.790 & 0.945 & 1.193 \\
\hline $\mathrm{Mn}_{3} \mathrm{O}_{4} \ldots \ldots \ldots \ldots \ldots$ & () 187 & & () 153 & 0.200 \\
\hline $\mathrm{K}_{2} \mathrm{O} \ldots \ldots \ldots \ldots \ldots$ & 0.272 & 1.300 & 0.710 & 0.925 \\
\hline $\mathrm{Na}_{2} \mathrm{O} \ldots \ldots \ldots \ldots \ldots$ & 0.391 & 2.630 & 1.280 & 1.668 \\
\hline & 99953 & 99.410 & 100.057 & 100.087 \\
\hline
\end{tabular}

Acidic Elements in the Soils.......... = 35.147 Per cent.

Basic " " $"$ "...........

Total Nitrogen in the Soils ............. "

Soluble in 3 per cent. $\mathrm{K} \mathrm{O} \mathrm{H}$, in 30 hours $=0.347$

Insoluble "6 "

It is understood that these analyses are of soils derived from the same lavas and lava flows; so that any differences indicate the measure of the action of climatic comditions, the upland soils showing the efferts of gleater rainfall.

Very noteworthy is the difference in the relative pro. portions of soluble and insoluble silica. In the upland soils the insoluble is the greater, whilst in the lomland the soluble silica has accumulated. The enormons amount of soluble silica in all the soils will be spoken of again. A notably greater increase of iron is seen in the upland soils, with a reduction of the alumina. In the lomlands, the lime is appreciably higher than in the 
uplands, whilst the phosphoric acid is just the reverse. But from the analyses it would not appear that there is a difference that could seriously affect the fertility, since the upland soils contain an ample total amount of the elements of fertility for an indefinite length of time. The question, however, which concerns the immediate crop is not the total, but the available amount of the elements indispensable to fertility. In the second part of this work the relative state of availability of the elements in the upland and lowland soils will be fully considered. Finally, it is noticed that, in respect of the combustible organic matter and the nitrogen contents of the upland and lowland soils, these tables of analyses fully support the data already furnished in showing that these soil constituents are in proportion relative to the rainfall.

The nature of the nitrogen compounds in the soil will not be considered in detail at this time. So far, the data show that $70.4 \%$ of the total nitrogen in the soil is soluble in a $\mathbf{3} \%$ cold solution of potassic hydrate, under an action of 30 hours duration. Concerning the watersoluble nitrogen, it is indicated that this is largely in the form of amido-acids. Qualitative tests, in which the soil was digested for 30 hours at a temperature of t5 degrees centigrade, and the solution treated with mereuric nit. rate, gave ample indications of amido bodies being present. This matter is of signal importance on account of its bearing upon the question as to the form of the nitrogen in which plants, growing in acid soils, take 1 p their nitrogen, a question to which we have already re. ferred, and to which we shall recur.

In presenting our observations upon the relation of rainfall to the organic matter and nitrogen in soils, we have to call attention to the fact that other observers 
have reached conclusions of a directly opposite nature. Professor Hilgard ("Relations of Soil to Climate") fur. nishes data showing that the "humid soils" in the United States contain less organic matter than the "arid soils." His conclusions result from the averaging of not less than 779 soils, and, on account of the reputation of the author, require a very careful attention.

In recapitulating the conclusions set forth in the pre. vious paragraphs we have, with the aid of our present knowledge, been led to consider the types of Hawaiian soils as follows:

\section{A.-Geological Classification.}

1. Dark Red Sorts. Soils formed by the simple weathering of normal laras, in climatic conditions of great heat and dryness.

2. Yellow and Light Red Soils.-Soils derived from lavas that underwent great alteration, under the action of steam and sulphurous vapors, at the time of, or after emission from the craters.

3. Sendientary Sorms.-Soils derived from the decomposition of lavas at higher altitudes, and the remoral and deposition by rainfall at lower levels.

It has already been said that there are soils which can not with certainty be placed under any one of these three types.

B.-Climatic Classification.

1. Upland Sorts. - Soils formed under lower temperature and greater rainfall, and distinguished by a large content of organic matter and nitrogen, and by a low content of the elements of plant food in an arailable state; these elements having been removed by rainfall. 
2. Lowlaxd Sorts.-Soils formed under higher temperatureand smaller rainfall, amb distinguished by a lower content of organic matter and nitrogen, and by a higher content of the elements of plant food in a state of immediate arailability, which is due in part to the receipt of soluble constituents from the upper lands, and to a smaller rainfall over the lower levels.

\section{RETATIVE FERTILTTY OF TIE NEVERAL TYPEA OF SOIJS.}

The "dark red soils," found in districts already described, and the "sedimentary soils" are more or less, and almost uniformly, fertile soils.

The "yellow and light red soils" are not marked by anything like the same uniformity in character and fertility. Certain of these, when first brought under cultivation, produce good arops, but the somre of fertility is not permanent. When two or more crops hare been removed the power to produce weakens greatly, and the restoration and maintenance of fertility is difficult, special treatment being required. Others of these soils, marking small or larger areas near the center's of a past great volcanic activity and chemical action on the lavas, from the first are not productire. In three special locations the managers of plantations have respectively said to the writer "the cane will not grow in this bright red soil." "Wherever that light red soil is mixed in with the other the land is poisoned." Further, "when the cane roots strike that old brown-yellow stuff they turn up and will not face it." Now, in each of the soils from the three locations quoted we have found more than 1.0 per cent. of sulphuric acid, which is in combination with 
the low oxide of iron, thus prorlucing a compoumd actually poisonous to plant life.

We had suspected the presence of these poisonous iron compounds, and the special examinations have con. firmed the supposition. Knowing, howerer, what certain of the fundamental reasons of non-productiveness are, we shall now be able to grapple with the trouble, and, in time, neutralize the causes of sterility.

In order to furnish a more definite idea of the relative productiveness of the different types of soils, we shall present certain data now in our hands. We shall first explain that a system of control is in use by which the production of each sugar plantation upon the four islands is known. Each plantation furnishes to the Bureau of this experiment station an annual statement, showing the number of acres of cane manufactured, and the sugar produced. 'The writer, by reason of the repeated visits to each plantation, and his knowledge of the type ol types of soil on each plantation, has been able to arrange the soils of each plantation under their proper types, and to attach to each its actual production. In the following table are included data only from plantations where soils of a definite type or types are found, and where the conditions of water-supply and temperature are com. paratively uniform. Great variations in these physical conditions could upset any comparison based upon variations in the types of soils. The data are not a state. ment of one crop, but represent the average of the past three years, and are therefore free from any incidental deviations from the mean. The data bearing upon the three types of soil are as follows: 


\begin{tabular}{|c|c|c|}
\hline Types of Soils. & $\begin{array}{l}\text { Approximate } \\
\text { No. of Acres. }\end{array}$ & $\begin{array}{c}\text { Yield of Sugar } \\
\text { Per dere. }\end{array}$ \\
\hline 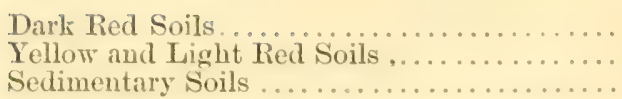 & $\begin{array}{l}30,000 \\
32,000 \\
20,000\end{array}$ & $\begin{array}{r}10,411 \mathrm{lbs} . \\
6,291 \text { " } \\
10,301 \text { " }\end{array}$ \\
\hline
\end{tabular}

The cane crop on these islands, allowing for the time of preparing the ground before planting, is two years in production, and two crops are always in course of growth at the same time. The "approximate number of alces" wiren allows for this comsigleation, which implies

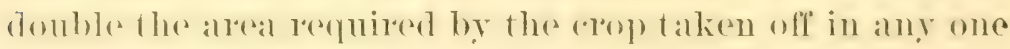
year. The land areas not embraced in this table would fall chiefly under the type of the "yellow and light red soils" were it possible to include them. It is seen that the "dark red" and "sedimentary" soils are vastly more productive than the "yellow and light red" soils. One feature in favor of the latter is the circumstance that whilst they produce mulh less in quantity, the pualiter, taling the (ande copol as an example, is distinctly higher. This is exemplified by the following table, which giree the profluetion of reptain sedimentary and yellow soils from sereral districts.

\begin{tabular}{|c|c|c|c|c|}
\hline Soils. & $\begin{array}{c}\text { Tons of Cane } \\
\text { Per Acre. }\end{array}$ & $\begin{array}{l}\text { Purity of } \\
\text { the Cane } \\
\text { Juice. }\end{array}$ & $\left|\begin{array}{c}\text { Tons of Su- } \\
\text { gar per } \\
\text { Acre. }\end{array}\right|$ & $\begin{array}{l}\text { Tons of Cane } \\
\text { to One Ton } \\
\text { of Sugar. }\end{array}$ \\
\hline $\begin{array}{l}\text { Seclimentary soils „a } \\
\text { Yellow or light Red Soils. }\end{array}$ & $\begin{array}{l}47.80 \\
23.60\end{array}$ & $\begin{array}{l}\text { Per cent. } \\
81.2 \\
90.5\end{array}$ & $\begin{array}{l}.511 \\
3.08\end{array}$ & $\begin{array}{ll}9 & 1 \\
8 & 1\end{array}$ \\
\hline
\end{tabular}

Tn eateh example nsed in this complarison the sedimentary and yellow soils are upon the same plantation; con. sequenty the mannfarturing data are strodly compara. tive, the same mill and mode of treatment being used 
upon the cane from the two kinds of soils. Neverthe. less, it is apparent that the different types of soil vary greatly in economic productiveness. The yellow and light red soils, by special treatment, can doubtless be increased in fertility. 'They cannot, however, in our

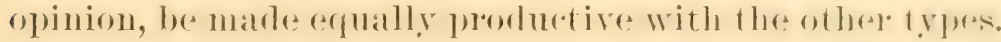
But for the good management, and very conspicuous acomomy praticed upon rertain plantations where the: yellow and light red soils predominate their position would be other than it is to-day.

Comparison of Hawaitax and American Soms.-At the close of the examination of the Hawaiian lavas, we bromght these into comparison with the kinds of renkis found in North America. It will now be of interest and value to compare the soils derived from the American rocks with the soils of these islands, which we have dis. cussed. A great geological interest will be found in

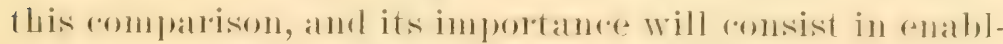
ing us to grasp the signifianee of striking variations, and in guarding us against applying ronclusions dlanw from the study of given soils, formed under their own rharacteristir: conditions, to of here absolutely different types of soils, which have resulted from rocks and con. ditions of quite dissimilar kinds.

For the purpose of the comparison, we have examined the soil analyses publisherl by the several experiment stations of the Enited States, and have reseiverl eopies of analyses marle by the laboratory of the Uniterl Statea Trepartment of Agriculture, Washington, miler the direction of Dr. H. W. Wiley, through whose courtesy they have been placed at onr disposition. Areompanying the analyses, Dr. Wiley writes "unfortunately a large part of the soil analyses a vailable have been marle acrolol? 
ing to different methork, and are not comparable. I send you the analyses of twenty different soils which were madle in this labolatory by the same method." These analyses furnished by Dr. Wiley were the usual "agrianl. tural analyses," and therefore dir not furnish data for a geological comparison with the "absolute analyses" made of Hawaiian soils.

In the absence of data corresponding to our purpose we sent to thirty experiment stations in the United States asking for small samples of soil from the experiment fields to be sent to us. Most of the stations respomeed to om lequest, including the States of Rhode Island, New IImpshire, Maine, New Jersey, Michigan, Illinois, Indiana, Ohio, Wisconsin, Kentucky, North Carolina, Missonli, Temmessees, Texas, Nebraska, Iowa, Minnesota, North Daliota, Itaho, Washingtom. Namples from of her States were received, but too late for use in the examination. It is thus seen that the greater part of the soils

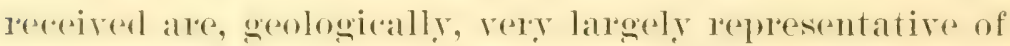
the American regions of glacial action and "drift" form. ation; and further, that they are mainly derived from rocks, whose origin was anterior to the laying down of the carboniferoms formations, atmixed with others, over given areas, which had a volcanic origin. It is in nowise claimed that these represent fully American soils.

As only an average composition of these American soils was required, one sample was made up by taking

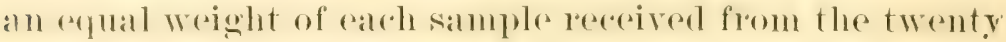
States; the samples, instead of the results of separate analyses, being averaged. The analyses were made pre. cisely the same as those of the Hawaian soils. The re. sults are as follows: 
COMPOSITION OF AMERICAN SOILS.

\begin{tabular}{|c|c|c|c|c|}
\hline $\begin{array}{l}\text { Constituent } \\
\text { Elements. }\end{array}$ & $\begin{array}{c}\text { Agricultural } \\
\text { Analysis. }\end{array}$ & $\begin{array}{l}\text { Insoluble } \\
\text { Residue. }\end{array}$ & Absolute & Analysis. \\
\hline $\begin{array}{l}\text { Insoluble Matter .. } \\
\text { Moi-ture ......... }\end{array}$ & $\begin{array}{c}\text { Per cent. } \\
84.890 \\
1.950\end{array}$ & $\begin{array}{l}\text { Insoluble } \\
\text { in } \mathrm{t} \mathrm{Cl} \text {. }\end{array}$ & $\begin{array}{l}\text { Water-free } \\
\text { Soil. }\end{array}$ & $\begin{array}{l}\text { Mineral } \\
\text { Matter }\end{array}$ \\
\hline 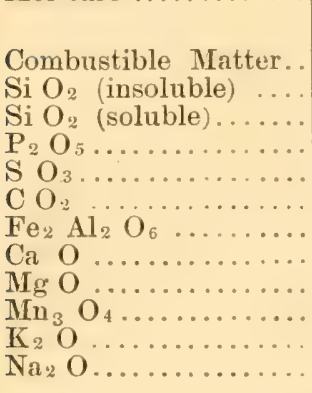 & \begin{tabular}{|c|}
5.077 \\
$\cdots \cdots \cdots$ \\
$\cdots$ \\
0.192 \\
0.072 \\
0.035 \\
6.230 \\
0.255 \\
0.354 \\
0.260 \\
0.237 \\
0.213
\end{tabular} & 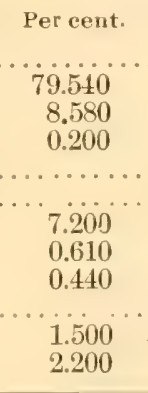 & $\begin{array}{c}\text { Per cent. } \\
5.180 \\
69.017 \\
7.393 \\
0.343 \\
0.073 \\
0.037 \\
12561 \\
0.787 \\
0.731 \\
0.265 \\
1.530 \\
2.114\end{array}$ & $\begin{array}{c}\text { Per cent. } \\
72.697 \\
7.840 \\
0.361 \\
0.077 \\
13250 \\
0.830 \\
0.771 \\
0.278 \\
1.622 \\
2.229\end{array}$ \\
\hline & 99.762 & 100.270 & 100.031 & 99954 \\
\hline
\end{tabular}

Acidic Elements in the Soil......... $=81.014$ Per cent.

Basic " " .......... . $=18.990$ "

Total Nitrogen in the Soil ......... "

Absorptive power of the Soil $\ldots \ldots \ldots \ldots=48.4$

The statement of analysis puts before us a type of soils fundamentally different in structural composition from Hawaiian soils.

In the first place, is noted the relative state of solubility of the constituents in the two soils, which is set forth by the "agricultural analysis." The relative proportions of the respective soils that were found soluble by warm digestion with concentrated hydrochloric at id were as follows:

\begin{tabular}{|c|c|c|}
\hline Soils & Soluble. & Insoluble. \\
\hline & Per cent. & Per cent. \\
\hline 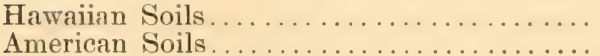 & $\begin{array}{l}68.894 \\
15.110\end{array}$ & $\begin{array}{l}31.106 \\
84.890\end{array}$ \\
\hline
\end{tabular}


This enormons difference in the relative proportions of the two soils that yield to the solvent action of strong hydrochloric acid is due to the fundamental difference in structural composition. The American soils are highIy acidic, and the Hawaiian ultra-basic in constitution, which is shown by the following comparison:

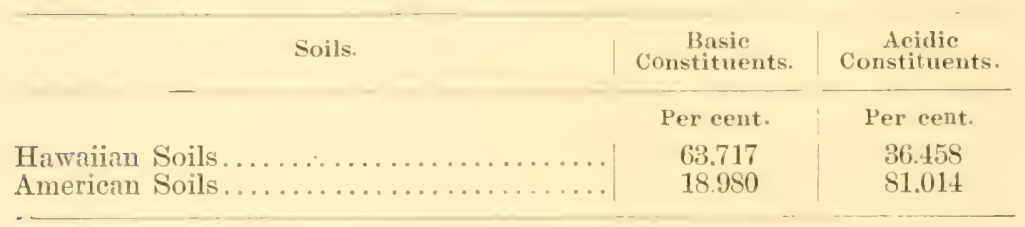

A more extreme difference in the fundamental structure of soils than is set forth by these data is not conceivable. The comparatively small action of strong hydrochloric acid upon the American soils is amply ex.

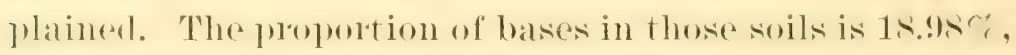
or less than one-fifth of the total mineral matter; whilst the proportion of the mineral matter soluble in the stromg acid was $16.25 \%$. 'The nature of the great variation in the proportions of bases in the soils of the Cuited states and of these Islands is set forth by the following com. parison:

\begin{tabular}{|c|c|c|c|c|c|}
\hline Soils. & \begin{tabular}{|lll}
$\mathrm{Fe}_{2}$ & $\mathrm{Al}_{2}$ & $\mathrm{O}_{6}$
\end{tabular} & $\mathrm{CaO}$ & $\mathrm{Mg} O$ & $\kappa_{2} O$ & $\mathrm{Na}_{2} \mathrm{O}$ \\
\hline 80 & $\begin{array}{l}\text { Per cent. } \\
59240\end{array}$ & $\begin{array}{c}\text { Per cent. } \\
0698\end{array}$ & $\begin{array}{c}\text { Per cent. } \\
1.242\end{array}$ & $\begin{array}{c}\text { Per cent. } \\
0737\end{array}$ & $\begin{array}{c}\text { Per cent. } \\
1.420\end{array}$ \\
\hline American Soils. & 13.250 & 0.830 & 0.771 & 1.622 & $\begin{array}{l}1.420 \\
2.229\end{array}$ \\
\hline
\end{tabular}

'These data require very little immediate comment. It is shown that the cardinal difference lies in the relative contents of iron and alumina. Concerning the lime and 
magnesia it is less important to note the similarity in amounts than to remenber the notable difference in the state of solubility in the respective soils. The complaral tive amounts of potash and soda in the American soils indicate matters of geological interest, as well as of agricultural moment, to which we shall recur.

The small proportion of basic elements in the Amer. ican, as distinguished from Hawaiian soils, involves a high content of acidic constituents, the bulk of which is composed of silicic acid, or silica. In drawing a comparison between American and Hawaiian soils we note not only the relative difference in total amounts, but also in the proportions of "soluble" and "insoluble" silica, and this latter difference has a very profound agricultural and geological significance. The followiug figures give the relative amounts of soluble and insolu. ble silica.

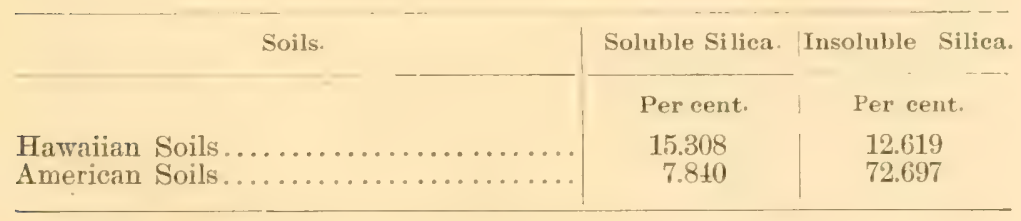

The mineral matter of the American soils contains no less than $80.537 \%$ of silica, only $7.840 \%$ of which is asso. ciated with bases that are soluble in strong hydrochloric acid. The total silica found in the average of more than 1300 sub-samples of Hawaiian soils is merely $27.927 \%$. And of these 27.927 parts, only 12.619, or actually $44 \%$ of the total silica, are insoluble; the greater part being combined with the bases, and is set free by the action of the strong hydrochloric acid. The soluble silica in the 
Hawainan soils is just domble the amount found in the American samples. Agriculturally this is probably of high importance, especially in the matter of the cane erop, and of all cereal growths which incorporate large quantities of silica in their composition. 'This, and other questions we are investigating in connection with the physiological development of the cane, and the amounts of the elements in the soil that are probably immediately avalable for plant growth.

In addition to the agricultural significance that the different contents of silica maly imply, not only these differences in the proportions of soluble and insoluble silica in American and Hawaiian soils, but the general structure, and present composition, of these widely different types have for us a high geological interest and value. In the matter of Hawaian soils we are first impressed with the low amount of the total silica and secondly, with the high proportion of this that is soluble. Both

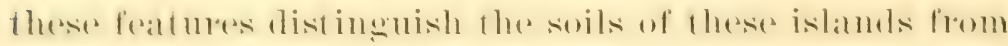
those of America, and of all geologically old countries, such as England and Germany, whence, through the comtesies of I'rof. Maercker, in Germany, and Messr's. Lawes and Gilbert, in England, we have received mumerous analyses. Moreover, the total silica found in Hawaian soils is rery much less than is found in the normal, solid lavas from which they were derived. In a comparison of the silica, we also repeat the statement of the iron and almmina in the lavas and soils.

\begin{tabular}{|c|c|c|c|}
\hline Muterials. & $\mathrm{Si} \mathrm{O}_{2}$ & $\mathrm{Fe}_{2} \mathrm{O}_{3}$ & $\mathrm{Al}_{2} \mathrm{O}_{3}$ \\
\hline & Per cent. & Percent. & Percent \\
\hline 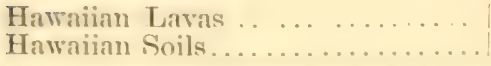 & $\begin{array}{l}+7.590 \\
27.927\end{array}$ & $\begin{array}{l}15.02 \\
36.44\end{array}$ & $\begin{array}{l}19.92 \\
22.63\end{array}$ \\
\hline
\end{tabular}


It is thins seen that the soils contain $41.3 \%$ less silica than the lavas; and we have already seen that of the total silica still found in the soils, $56.0 \%$ is "soluble silica." We have already said that these features distin. guish Hawaiian soils from those of geologically older comntries, and particularly those of America that we have submitted to an absolute analysis.

Returning to American soils, it is not possible, even with an approximation to accuracy, to submit these to a comparison with the rocks from which they have been derived, in the precise mode followed with Hawaiian soils. There are regions in the United States where a true geological study of the soils may be made in con. nection with an examination of the rocks from which the soils actually came. And in the Western States, mone especially where rolcanir merks (which clarke and Hillebrand have shown to be normal basalts) have cor. ered notable areas, it may be possible to find relations of lavas and soils which, although now older, were juimarily idential with the relations on these islands. We merely suggest that it may be possible.

The American soils composing the collective sample that we ane using in this comparison, it has alrearly been sairl, are rhirefly frem regions where the rock formations

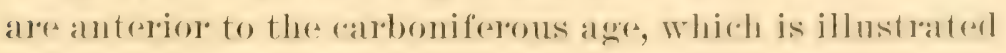
by a geological map of the United States. These early formations fall under the grand divisions of Archaen,

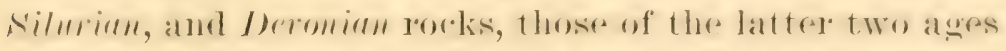
(o) The Arehalean formations include granitic, hornblenclic,

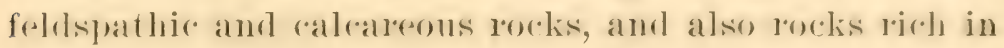
iron, and locally in titanic acid. The lower and upper silurians (mblarer samblstomes, silireous slates, rlaystomes 
and shales; and also limestones on a large scale. The lower Deronian rocks, according to Dana, "represent the great limestone making period of the age in America, whilst the later Deronian formations are mostly shalea or sandstones." These formations rum on also into those of the sub-atroniferoms perionl, during which the initial work was beem in laving down the formations that matk the carboniferous age.

In the selections that we have made from the superb series of analyses of American rocks made by Messrs. Clarke and Hillebrand, U. S. Geological Survey, which may well be used by agricultural chemists in America as indicating the nature of a primary basis for an actually scientific study of soils in the United States, are found examples of the composition of most of the rocks which comprise the formations of the early geologic ages that have been named. 'The authors, however, would not claim that those analyses are adequate to enable us to estimate the mean composition of the rock masses which compose the surface formations corering the areas of the vast regions from which the soils were taken. The composition of the several kinds of rocks is furnished by these analyses; but the relative geographical areas that are ocenpied by the respective formations are not known, and without these anything of the nature of an approximate average cannot be attained. Nevertheless, and while the arelage of the composition of the sereral kinds of Amerian rockis will mot furmish us with the knowledere that is required, the data can aid in our present purpose; so that we shall reproduce the mean of the compositions of the rocks by the side of the mineral constituents of the American soils . 


\begin{tabular}{|c|c|c|c|c|c|c|}
\hline Materials & $\mathrm{Si} \mathrm{O}_{2}$ & $\mathrm{Fe}_{2} \mathrm{Al}_{2} \mathrm{O}_{6}$ & $\mathrm{CaO}$ & $\operatorname{Mg} \mathrm{O}$ & $\mathrm{K}_{2} \mathrm{O}$ & $\mathrm{Na}_{2} \mathrm{O}$ \\
\hline & Percent & Percent & Per cent. & Per cent. & Per cent. & Per cent. \\
\hline American Rocks & 5393 & 18.81 & $\begin{array}{l}9.42 \\
0.83\end{array}$ & $\begin{array}{l}2.10 \\
0.77\end{array}$ & $\begin{array}{l}231 \\
1.62\end{array}$ & $\begin{array}{l}1.67 \\
2.23\end{array}$ \\
\hline
\end{tabular}

By this comparison we reach results which are abso. lutely the opposite of the results from comparisom of the Hawaiian lavas and soils. The Hawaiian soils contain 27.92 parts less silica than the lavas; whilst the American soils contain 26.61 parts more silica than the rocks. Concerning the chief bases, the Hawaiian soils contain 24.13 parts more of iron and alumina than the lavas; and the American soils $\mathbf{5 . 5 6}$ parts less of these constituents than the rocks. In the matter of the silica, we again allude to the high content of soluble silica in Hawaiian, and the insoluble state of the silica in American soils.

We have already said that the results of a comparison of American soils and rocks do not bear the same weight of significance as the comparison of Hatrailan soils and laras, for the reason that we do not know the proportions of the several kinds of rocks that have gone to the forming of the American soils. We do not know that their averages of silica amounted to $53.93 \%$. It may have been less, but probably was more. It appears quite certain, however, that the average of silica in the great rock masses did not contain anything like the amount of silica found in the American soils derived from those rocks. Even the granites contain only $72.0 \%$ of silica, $01^{\circ} 8 \%$ less than the soils, and it appears further certain that the silica average could not be equal to that of the granites when the vast areas of claystones, slates, shales, loess, silicates and carbonates of iron, and limestones, 
whose arerages result in $43.3 \%$ of silica, are included. Again, the iron and alumina found in the American soils indieate that formations of the mat mee of elaystones, slates and shales have contributed notably to the produce tion of the earths overying the vast areas traversed by glacial drift. Moreorer, the rocks that would likely contribute the most to the formation of the drift soils would be such as yielded more easily to the glacial action, and the siliceous sandstones, which contain less silica than similan residual products of rock disintegration on these Islands, and the granites would not be of that order. In brief, the indications are that those collective rock formations contained notably less silica than is found in the soils that have been derived from them, but we bear in mind that these are, at present, only indications.

With these extraordinary marks of difference, in the structure and rhemical composition, between Ilawaian and American soils the question naturally follows con. rerning the "anses and modes of chamge from which this fundamental distinction has resulted. The American soils are old, and have, comparatively considered, reached a state beyond which little further change is possible. On the other hand, the soils of these Islands are all geologically very recent, and over certain areas they are very new, whilst special lava flows occurred so short a time ago that the rock camnot yet be said to be chatlged into soil. This youthful state of Ifawaian soils povirles an exeellent possibility of noting not only the

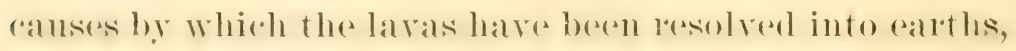
but also indications of the modes and slow processes by which soils of a given structural composition and type may molexwo intrinsice rhange and pass orele into soils of another type, having a totally different composition. 
In the first place we shall repeat the comparison of Hawaiian lavas and soils.

\begin{tabular}{|c|c|c|c|c|c|c|c|}
\hline Materials. & $\mathrm{Si} \mathrm{O}_{2}$ & $\mathrm{Fe}_{2} \mathrm{O}_{3}$ & $\mathrm{Al}_{2} \mathrm{O}_{3}$ & $\mathrm{CaO}$ & $\mathrm{Mg} \mathrm{O}$ & $\mathrm{K}_{2} \mathrm{O}$ & $\mathrm{Na}_{2} \mathrm{O}$ \\
\hline & $\begin{array}{l}\text { Per } \\
\text { cent. }\end{array}$ & $\begin{array}{c}\text { Per } \\
\text { cent. }\end{array}$ & $\begin{array}{c}\text { Per } \\
\text { cent }\end{array}$ & $\begin{array}{l}\text { Per } \\
\text { cent. }\end{array}$ & $\begin{array}{c}\text { Per } \\
\text { cent. }\end{array}$ & $\begin{array}{c}\text { Per } \\
\text { cent. }\end{array}$ & $\begin{array}{l}\text { Per } \\
\text { cent }\end{array}$ \\
\hline Hawaiian Lavas & 47.90 & 13.36 & 18.23 & 8.99 & 6.05 & 1.50 & 2.20 \\
\hline Haw aiian Soils. & 27.92 & 36.44 & 22.63 & 0.69 & 1.24 & 0.74 & 1.42 \\
\hline
\end{tabular}

This statement of lavas is based upon the inclusion of moisture and combined water; in other statements of the same laras the water is excluded, in order to compare with other water-free materials. These data rep. resent the enormous change in the relative proportions of the elements in the course of passage from lara to soil. This change took place slowly, which is shown by the previous statement on the "weathering lavas;" and the soils are still in a state of change, which it is possible to illustrate. Of the total silica still in the soils, it has already been shown that $56 \%$ is "soluble silica," and liable to gradual remoral. That it is being remored is shown by an examination of the composition of the discharge waters leaving the four large islands, that is given in the second part of this work, in which it is seen that the silica contained in the waters is twice as great as either the lime or magnesia; five times greater than the potash; fire times greater than the combined iron and alumina, and only equalled by the soda. Whether this soluble silica exists in the free state in the soils in part, or is wholly combined with the bases, has not yet been determined; but there are indications that the silicates of iron and alumina are slowly disintegrating, the silica 


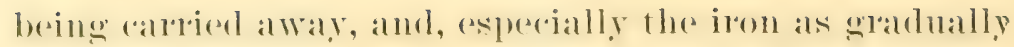
aggregating.

In the matter of the removal of the bases it is seen that the lime has gone with the gleatest farcility-the alement that is most vital when we come to the relations of the soil to plant life. Of the alkalies, soda has been the most resistant. It is remembered, however, that the most of the soda is bound up in the "insoluble residue," laving resisted the solvent action of the concentrated hydrochloric acid. 'This behaviour of the soda suggests a link of relationship between the Hawaiian, and the old American soils. The alumina is slightly higher in the soils than in the lava; yet it has been remored on a vast scale. 'There were five parts more of alumina than iron in the laras; but there are fourteen parts more of iron than alumina in the soils. This denotes the relative behaviours of these bases in the changes that are trans. piring.

In the course of examination of the different Hawaiian soils we have noted a difference, in degree, of behaviour of soils formed under dissimilar conditions. Soils deriv. ed from tufa lavas, which underwent chemical action during the initial stage of disintegration, contain ten palts less of tolal silical, and eight parts less of soluble silica, than the soils formed by the weathering of normal lavas in dry conditions. Again, the "upland" soils contain two parts less of total silica, and three parts less of soluble silica than the lowland soils. This results, in part, from the riremustance that the rainfall upon the uplands is double that of the lowlands. It is unquestionably due also, to the further circumstance that the uplands soils, with the large content of decaying organic 
matter, are five and one-half times more acid than the lowland soils, which we have carefully observed.

The agricultural analyses have shown that the soils contain an amount of silica that was not disturbed by the digestion with strong hydrochloric acid, and not removable from the insoluble residue with alkalies; which is understood as "insoluble silica." In the course of the advancing disintegration of the soils, and of the separation and removal of the soluble silica, the stage in the history must be reached when the insoluble silica must become an increasing factor, and not only in relation to the soluble silica, but as a constituent of the whole soil. For it is not only shown that the soluble silica is being actually carried away, there are numerons indications that even the iron, which has accumulated so enormously in passing over from the lavas into the soils, reaches a degree of concentration when it separaltes from the other constituents, and forms layer's and concretions of iron ore. We have, in a former table, given four analyses of such concretions, where the separation of the iron had been precipitated by chemical action on the lavas, the arerage of which gave $78.41 \%$ of iron oxide. These concretions we have found on an appreciable scale on the older Islands of Oahu and Kanai. In relation to the stage or time when the "insoluble silica" shall begin to assert itself in the composition of the soils, it is noted that the upland soils already, not only contain more insoluble than soluble silica, but also more insoluble silica than the lowland soils. It is here suggested that rainfall and acidity are operating along the line of a change in the type of the soils. In the con. ditions of nature the change must be very slow.

In another place we have shown that when an one per 
cent. solution of citric acid had acted on a soft lava for about fifty days, the lava was wholly taken to pieces, the bakes being chiefly in solution, leatring a resichue com. posed of insoluble silical and silicates. This disinterara. tion with the weak organic acid required fifty days for completion. Proceeding from the weak, to the use of a strong acid, it is shown by the agricultural analyses that the same was areomplisherl on the soils in tem homp's, and leaving insoluble residues containing over $75 \%$ of insoluble silica and titanic acil. These insoluble residnes however, comprise only $31.1 \%$ of the original soil; so that to produce the insoluble residues of their present (a)mposition, $68.9 \%$ of the more soluble parts of the soil had to be remored. We cannot compute how long a time might be required by Nature to accomplish what was done by the strong hydrochloric acid in ten hours. Moreover, we do not know that the sum of natural processes will be exactly in the same direction, or that they will lead to the same results. At this place, however, we call attention to the impressive circumstance that when Hawailan soils ale digested with comerentrated hydrothloric

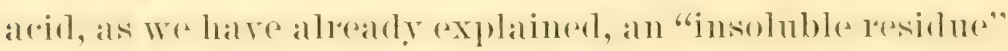
remains which is almost identical in chemical composition with the American soils. We bring these into com. parison;- the insoluble residues, all of which are preserverl, reporesenting some 1:300 sub-samples of II a wailan soils.

\begin{tabular}{|c|c|c|c|c|c|c|c|c|}
\hline & Materials. & & $\mathrm{SiO}_{2}$ & $\mathrm{Fe}_{2} \mathrm{Al}_{2} \mathrm{O}_{6}$ & Ca $O$ & $\mathrm{Mg} 0$ & $\mathrm{~K}_{2} \mathrm{O}$ & $1 \mathrm{Na}_{2} \mathrm{O}$ \\
\hline & & & $\begin{array}{c}\text { Per } \\
\text { cent }\end{array}$ & $\begin{array}{l}\text { Per } \\
\text { cent. }\end{array}$ & $\begin{array}{l}\text { Per } \\
\text { cent. }\end{array}$ & $\left|\begin{array}{c}\text { Per } \\
\text { cent. }\end{array}\right|$ & $\begin{array}{c}\text { Per } \\
\text { cent }\end{array}$ & $\begin{array}{c}\text { Per } \\
\text { cent. }\end{array}$ \\
\hline $\begin{array}{l}\text { "Insoluble } \\
\text { Shoils.... } \\
\text { American So }\end{array}$ & $\begin{array}{l}\text { Residues," } \\
\text {. . . . . . . . . }\end{array}$ & $\begin{array}{c}\text { Hawaiian } \\
\ldots \ldots \ldots \ldots \\
\ldots \ldots \ldots \ldots\end{array}$ & $\begin{array}{l}76.53 \\
80.54\end{array} \mid$ & $\begin{array}{l}18.66 \\
13.25\end{array}$ & $\begin{array}{l}0.71 \\
1.83\end{array}$ & $\begin{array}{l}0.86 \\
1.77\end{array}$ & $\begin{array}{l}0.70 \\
1.62\end{array}$ & $\begin{array}{l}1.64 \\
2.23\end{array}$ \\
\hline
\end{tabular}


It is seen that by acting upon Hawaiian soils with strong hydrochloric acid for ten hours, and removing the acid soluble constituents, we have an insoluble residue left, of the same color and similar composition as the American soil, according to the absolute analysis of the latter. If the hydrochloric acid had removed $5 \%$ more of the alumina and iron, the silica in the insoluble residne would have been exactly equal to the amount in the American soils. We have previously said, however, that a further treatment of the insoluble residne with a fresh quantity of the strong acid did not appreciably reduce its weight or composition. We have also said that we do not know that the natural processes are acting exactly along the same line, or will lead to the same results as are accomplished by the strong hydrochloric acid in ten hours. We have however, furnished such natural indications as we have observed, showing that the slow action of dilute arids, or more properly speaking of acidulated waters, does appear to be moving towards the results which are more instantly produced by the strong acid. If these results should be eventually reached, and the soils of these Islands be converted into a type represented by the insoluble residue, and resembling American soils, the time required to that end will be immense; since, as it has been said, no less than $69 \%$ of the present, more soluble constituents have to be separated and removed.

These considerations bearing on Hawaiian soils lead to the question concerning the mode and processes by which the American type of drift soils, that we have examined, arrived at their present composition? Reasoms have already been given for deciding that those 1 merican 
soils have been derived from rorek formations that must, in the aggregate, have contained a much lower content of silica than is found in the soils. In fact there is not any ortere of roeks but the silieeous samelstones that rontains anything like so much silical as the drift soils that we are speaking of. Those sandstones howerer, are exsentially sepallation or residual products of previous formations; resembling the residual silideous products from the disintegration of Hawaiian lavas, that are to form future sandstomes, and in which ome analysis foumd $93 \%$ of silica, or $5 \%$ more than the mean of American sandstones. If then the rocks, and also the soils during an earlier period in their history, contained less silica than is now in the present soils, they must necessarily have containd more bases, and the question has alreally been put concerning the processes by which the soluble constituents have been removed, and the soils have reachsh their present composition, with the enomous content of silica. We have been specially concerned with the mode of formation of Hawaiian soils, and only generally interested, and for the value of comparison, with American soils. It has appeared to us, howevel, that such American soils as we have examined have reached their present composition and character by a long history of change that has proceeded by a comser of processes similar to what has been deseriberl. We have endeavored to obsereve some remaining records of surh processes in soils from sperial localities. By the comptesy of Professor Goodell, of the Amherst Experiment Station, Mass, we receiverl analyses of soils in the Comnecticut valley, lying at the feet of Mount Holyoke and Mount Tom, that are amongst the grandest results 
of the great eruptions of the Triassic periorl, and which are composed of basalts that, according to Dana, hare the same composition as the lavas of the Hawaiian Islands. Those soils, however, show an average "insolu. ble residue" of $85.37 \%$, according to the agricultural analyses; which indicates, as we thomght probable, that the Counecticut valley soils are soils of deposit, and bear no necessary relation to the rocks of the immediate locality; or that they have become so radically altered in type as not to resemble, in the least, the basaltic soils of these islands. (Our inquiries concerning areas in Europe, with which we are also familiar, have been just as resultless in this respect. Yet we are impressed that there are localities in the United States where such records may be found in the soils. Were this the place for such a discussion, it might be possible to present the most impressive indications showing that not only have the older soils been brought to their present state of composition by the processes recounted, but that those changes transpiring in the structure and composition of soils between the periods of virginity and old age are only a part and continuance of the initial processes of disintegration whereby the rocks were resolved into earths. Further, that it has been by the removal of the soluble constituents from soils, resulting in the changes of type, as rell as from the initial decomposition of rocks, that the materials have been derived for the laying down of the grand and successive series of formations which form the superficial crust of the earth.

How superficial the crust is that has undergone continual dissolution and deposition in new formations it is not possible to say. Of possible interest at this place, 
it is remarked that the specific gravity of Hawaian soils has been found to be 2.87, as compared with about 2.6, the specific gravity of certain American soils. The specific gravity of the Hawaiian soils, free from combustible matter, is approximately 3.4; compared with the lavas, having a specific gravity of almost exactly 3.0. It is seen that the specific gravity of the lavas is very little greater than that of the natural soils, or than the mean specific gravity of the surface of the crust of the earth. The specific gravity of the earth as a body, howerer, is 5.5. If then, we compare what must be the relatively smaller mass of the interior of the earth, hav ing a density so great as to bring the specific gravity of the globe up to 5.5, with the greater mass of the exterior of low deusity, it then appears that our lavas must come from a depth merely beneath the surface, comparatively speaking; and that the locality of their origin may bear no redation to the mole profomol internal depths and an ditions of our globe. With such questions, howerer, we bave nothing to do at this place and time.

Our considerations, so far, have dealt only with the origin and nature of Hawaiian soils. This knowledge is preliminary to any further investigations. We are, however, practically concerned with the economic rela tion of the soils to plant life and production, and this re. quires a knowledge, not only of the elements of plant food contained in the soils, but also of their condition of fituess for use by the growing erops. Consequently we have had to look into the state of availability of the essential constituents; the results of which further investigations will be given in the second part of this work. 


\section{AVAILABILITY AND LOSS}

\section{or the \\ ELEMENTS OF PLANT FOOD}

$1 \mathrm{~N}$

\section{HAWAIIAN SOILS.}

In the First Part of these investigations attention was confined to the "Origin and Nature of Hawaiian soils." We shall now endeavor to obtain some more definite and special knowledge of the solubility of these soils, and try to understand something of the state of availability of certain required elements in plant growth, and their behaviou mole the action of processes operating in Nature.

Before proceeding, it may be well to repeat how strictly necessary it is that the fundamental differences which we have shown do actually obtain between Hawaiian soils, and soils of America and other comntries, in the matters of relative and structural composition, and in the state of solubility, should be continually kept in mind. These differences persuade us at the outset that corresponding results cannot follow the action of either artificial solvents, or the processes of Nature, upon soils 
of such dissimilar composition. The primary cireumstance, that we are dealing with soils of a strongly basic nature, as compared with other soils of a highly acid character, suggests that the action of any solvents may be widely different upon the two orders of soils. These considerations then, should guard against the use of re. sults found upon Hawaiian soils, and in these conditions, in judging of the character of other and different soils, found in totally different conditions.

\section{T.MBORATOTR MODES OF ESTIMATIXY TIIE ELEMENTS OF PLANT FOOD AVATT. \\ ABLE IN SOILS.}

The annals of agricultural chemistry furnish the results of numerous and very dissimilar endearors to establish a means of estimating the proportion of the (2) (2ments important in plant nutrition which may be said to be available at the time of examination, for that purpose. Up to this time, those endearors have not resulted in any methods which appear to be in so far uniform as to agree in the recognition of the principles upon which, it may be found, such methods must rest. The

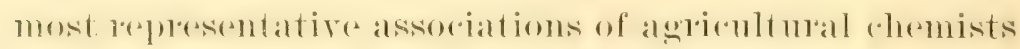
continue to oscillate between extremes that indicate the absemeref anything permanent in principle, or that promises to become uniform in practice.

Metiods AND Solvents.-In framing a method, and in the selection of solrents, for estimating the proportion of plant food posibly arailable in soils al the time of examination it seems necessary to be guided by an exact observance of the agencies by means of which the insol- 
uble soil-materials are being daily altered by the processes of Nature in the field into forms in which they can be used by growing plants.

The processes operating in Nature by which the elements are prepared as food, are physio-chemical; and for this reason the problem cannot be primarily considered from the analytical standpoint.

The solvent agents operating in Nature, in addition to water, are the acids moving in the sap of living plants, and operating on soils through the membranes of their roots, the chief one, as far as we know at present, being carbonic acid $\left(\mathrm{CO}_{2}\right)$; and, more important, the acids whirh result from the deray of regetable matter upon and within the soil.

The acids formed when plants, roots, and fruits decay are simple organic acids - carbon acids; and the amido acids - carbo-nitrogen acids. Therefore the acids in living, and produced by dying plant organisms are carbon acids, with or without nitrogen. In the complete decay of regetable matter these organic acids are resolved into ultimate mineral bodies; the carbon into carbonic acid, and the nitrogen into nitric acid, or nitrogen, the simple forms in which these were primarily taken from the air to build up the plant organism. Consequently the amounts of carbon and of nitrogen contained in plant organisms are respectively the measure of the relative amounts of simple carbon acids, and of amido acids that can be produced in vegetable decay, and of the amounts of carbonic and nitric acids that finally result from that decay, and which act as solvent agents on the soil. The minute amount of sulphuric acid, and the still smaller portion of phosphoric acid, that are formed from the 
sulphur in the proteids and mucleins, and from the phosphorous in the phospho-glycerides (lecithines) are mnoticed now.

In the absence of elementary estimations of the carbon and nitrogen in plant orwanisms, these estimations being confined to constituent bodies, we may come approximately to such determinations by ascertaining the amount of the constituents of plants that are composed of carbonaceous bodies not containing nitrogen, and the proportion of bodies that do contain nitrogen. The bodies free from nitrogen are the so-called nitrogen-free extract matter, the fiber, and, for our present purpose are added the fats. The bodies containing nitrogen are now collectively considered as proteids. The amounts of these nitrogenous and non-nitrogenous carbonaceous bodies found in a broadly representative series of agricultural plants are found in the following table:

\begin{tabular}{|c|c|c|c|c|c|}
\hline Materials. & $\mid \begin{array}{c}\text { No of } \\
\text { Examples }\end{array}$ & Proteids. & Fiber. & $\begin{array}{c}\text { Nitrogen-free } \\
\text { Extract--Matter }\end{array}$ & Fats. \\
\hline & & Per cent. & | Per cent. & Per cent. & Per cent. \\
\hline Legumes and Cereals & 32 & 8.0 & 27.6 & 51.5 & 3.1 \\
\hline Root and Bulbs..... & 14 & 139 & 10.5 & $6+.5$ & 3.1 \\
\hline Grain and other Seeds & 45 & 12.9 & 2.3 & 79.5 & 44 \\
\hline Means.......... & 91 & 11.6 & 13.5 & 65.2 & 3.5 \\
\hline
\end{tabular}

If the third series, the seeds, are excluded for the reason that the grain and seeds are not allowed to return directly to the soil, the means will remain nearly the same, the large proportion of extract matters in seeds being offset by the small amount of fiber. These data show that in the 91 examples of growths we have.

Nitrogen-free Carbnnaceons bodies . . . . = 82.2 Per cent.

Nitrogenous $\mathrm{C}$ :rbonaceons bodies....

$=116$ 
The nitrogen-free bodies may be considered as containing six parts of carbon $\left(\mathrm{C}_{6}, \mathrm{H}_{10} \mathrm{O}_{5}\right)$. The proteids, in which the elementary analysis finds $16 \%$ of nitrogen, with $54 \%$ of carbon, are bodies in which, according to the relative atomic weights, about three parts of carbon are associated with one part of nitrogen. The relation of the carbon and nitrogen present in these organisms, then may be expressed thus:

\begin{tabular}{l|c|c|c|c} 
& Per cent. & $r$. & \multicolumn{2}{|c}{ "arts of } \\
Nitrogen-free Carbonaceous bodies.... & $82.2 \times$ & $6=$ & 493.2 & Carbon \\
Nitrogenous Carbonaceons bodies..... & $11.6 \times$ & $3=$ & 34.8 & "6 \\
& & N. & 528 & "6 \\
Nitrogenous Carbonaceous bodies..... & $11.6 \times$ & $1=$ & 11.6 Nitrogen \\
\hline
\end{tabular}

These data indicate that in the composition of the plants, roots, and seeds stated there are forty-fire parts of carbon to one part of nitrogen. Therefore in the de. composition of those organisms there must finally be produced forty-five parts of carbonic acid and one part of nitric acid.

Nitric acid is a more immediately active solvent than carbonic acid, and will dissolve soil material rapidly while its action lasts. The duration and measure of its action, however, are fixed by the quantity, and can extend only to the point of neutralization with the bases it acts upon, which is the same with the carbonic acid. Moreorer, nitric acid is a mono-basic acid, while carbonic acid is di-basic; which thus doubles the solvent power of the forty-five parts of carbon and lowers the possible action of the one part of nitrogen to only one-ninetieth (1-90) part of that of carbonic acid, providing both acids exercise their action on the soil bases to neutralization. 
The above considerations have appeared to the writer to be a guide in the selection of solvents which are to compare, in any measure, with the action of processes operating in the field; and they led to the exclusion of mineral acids, and the use of simple carbon acids and amido acids in these investigations.

Citric Acid as a Sompent. - It is due to consider, the first in order, citric acid as a solvent, since not only has considerable work been done, and conclusions been reached, based upon the solvent action of this acid, it also exercises an accepted influence in the estimation of certain fertilizing materials of great economic importance. As an exception to omitting references to authorities generally, which is done to economize space, attention is called to the work of Dr. Bernard Dyer with citric acid, on soils.

The examinations and results to be recorded are not confined to observations made upon samples of soil taken by chance, but upon soils definitely selected in districts of the fou islands. On Oahu, samples were taken from Waianae, Ewa, Heeia and Waimanalo districts; on Kanai, from the Kekaha, Makaweli, Kealia and Kilauea districts; on Mani, from Hana, Paia and Wailuku dis. tricts; on Hawaii, from Hawi, Niulii, Ookala, Laupahoe. hoe, Hilo and Kan districts. These comprise 30, what we shall call, type samples; and 360 sub-samples; which means that each type sample represents some 10 to 15 sub-samples taken from a large area where the soil is of one type. As we have already remarked, the samples were taken personally by the writer, or in places, and by methods, advised by us. The superficial character of the land, elevation, exposure, and rainfall were noted, and attached to each sample, with its agricultural analysis. 
In addition to the care given to make the soils selected representative of the types found on all the islauds, these soils were resolved into two groups: Upland (mauka) soils; and lowland (makai) soils. This division was made in our report on soils in 1895 , and has been continued since, and denotes differences in the soils, which are mainly due to rainfall and other superficial causes.

In the thirty (30) type samples of soils spoken of, estimations were made:

First: Of the lime, potash, and phosphoric acid soluble in water.

Second: Of the lime, potash and phosphoric arid soluble in an $1 \%$ solution of citric acid.

At this place we state simply the mode of treating the soils with the solvents, leaving some observations to be made on methors for a later occasion.

In the estimation of elements soluble in water 200 grams of the field sample (not fine earth) were put into a closed funnel, with a ground glass cover, and treated with 1000ere of water for 48 hours, the water percolating through slowly, and then returned upon the soil, and continned for the time stated.

In determining the elements soluble in $1 \%$ citric acid solution, 200 grams of the field sample were put into a two-liter bottle with $1000 \mathrm{ce}$ of the $1 \%$ citric acid solution; the bottle was gently shaken every fifteen minutes during the dar portion of 24 hours, and at the end of this time filtered off. One reason for the shorter time of treatment with citric acid is its liability to fermentation in great dilution, a matter that will be spoken of later.

With these brief definitions, we now give tables of data which set forth the solvent action of water and 
citric acid respectively upon each of 30 type samples of soil, taken from districts on the four Islands, and representative of all our soils. We give the amounts of lime, potash, and phosphoric acid found by the agricultural analysis in each soil, with the amounts soluble in water and citric acid respectively, and the pounds per acre actually dissolved by the solvents. 'The individual statement of the behaviom of each soil under the action of the solvents is necessary in order to understand the range of variation, and the different forms of combination in which the elements exist in the soil, which is indicated by the variable ratio of solubility. The data occupy much space; but they also involved great labor and time in their preparation. We give first the data on Lime. 
LTME.

\begin{tabular}{|c|c|c|c|c|c|}
\hline $\begin{array}{c}\text { Laboratory } \\
\text { No. }\end{array}$ & $\begin{array}{l}\text { Lime in } \\
\text { Soil. }\end{array}$ & $\begin{array}{l}\text { Soluble in } \\
\text { Water. }\end{array}$ & $\begin{array}{l}\text { Pounds } \\
\text { per Acre. }\end{array}$ & $\begin{array}{l}\text { Soluble in } \\
\text { Citric Acid. }\end{array}$ & $\begin{array}{c}\text { Pounds per } \\
\text { Acre. }\end{array}$ \\
\hline & Per cent. & Per cent. & & Per cent. & \\
\hline 3 & 0.257 & 0.0057 & 199 & 0.145 & 5075 \\
\hline 5 & 0.112 & 0.0035 & 122 & 0.075 & 2625 \\
\hline 6 & 0.442 & 60029 & 101 & 0.195 & 6825 \\
\hline 12 & 0.330 & 0.0087 & 304 & 0.097 & 3395 \\
\hline 13 & 0.600 & & $\ldots \ldots$ & 0.053 & 1855 \\
\hline 14 & 0.510 & 0.0082 & 287 & 0.177 & 6195 \\
\hline 17 & 0.435 & $\ldots \ldots \ldots$ & $\ldots \ldots$ & 0.228 & 7980 \\
\hline 19 & 0.338 & 0.0065 & 207 & 0.103 & 3605 \\
\hline 2.2 & 0.200 & & & 0.061 & 2135 \\
\hline 25 & 0.800 & 0.0116 & 406 & 0.233 & 8155 \\
\hline 26 & 0.215 & 0.0024 & 84 & 0.043 & 1505 \\
\hline 43 & 0.448 & 0.0102 & 357 & 0.230 & 8050 \\
\hline 45 & 0.541 & $\ldots \ldots \ldots$ & $\ldots .$. & 0.147 & 5135 \\
\hline 46 & 0.473 & $\ldots \ldots$ & $\ldots \ldots$ & 0.118 & 4130 \\
\hline 47 & 0.168 & 0.0041 & 144 & 0.113 & 3955 \\
\hline 55 & 0.365 & 0.0103 & 361 & 0.177 & 6195 \\
\hline 60 & 0.080 & 0.0018 & 63 & 0.055 & 1925 \\
\hline 33 & 0.320 & & & 0.099 & 3465 \\
\hline 66 & 0.109 & 0.0009 & 31 & 0.030 & 1050 \\
\hline 69 & 0.350 & 0.0024 & 84 & 0.155 & 5422 \\
\hline 71 & 0.448 & 0.0046 & 161 & 0.171 & 5985 \\
\hline 84 & 0.095 & 0.0014 & 49 & 0034 & 1190 \\
\hline 90 & 0.120 & 0.0009 & 31 & 0.043 & 1505 \\
\hline 92 & 0.157 & 0.0018 & 68 & 0.031 & 1085 \\
\hline 93 & 0.092 & 0.0080 & 280 & 0.068 & 2380 \\
\hline 601 & 0.913 & 0.0026 & 91 & 0.281 & 9835 \\
\hline 604 & 0.473 & 0.0035 & 122 & 0.087 & 3015 \\
\hline 614 & 0.237 & $\ldots \ldots \ldots$ & $\ldots \ldots \ldots$ & 0.059 & 2065 \\
\hline 616 & 0.529 & $\ldots \ldots \ldots \ldots$ & $\ldots \ldots$ & … & $\ddot{m i n}$ \\
\hline 617 & 0.305 & $\ldots \ldots \ldots \ldots$ & $\ldots \ldots \ldots$ & 0.025 & 875 \\
\hline
\end{tabular}


PO'IASH.

\begin{tabular}{|c|c|c|c|c|c|}
\hline $\begin{array}{c}\text { Lallogritory } \\
\text { No. }\end{array}$ & $\begin{array}{c}\text { Potash in } \\
\text { Soil. }\end{array}$ & $\begin{array}{l}\text { Soluble in } \\
\text { Water. }\end{array}$ & $\begin{array}{l}\text { P'omnds } \\
\text { Per Acre. }\end{array}$ & $\begin{array}{l}\text { Soluble in } \\
\text { Citrie Acid. }\end{array}$ & $\begin{array}{l}\text { Pounds } \\
\text { Per Acre. }\end{array}$ \\
\hline & Per cent. & Per cent. & & Per cent. & Per cent. \\
\hline 3 & 0.250 & 0.0070 & 245 & 0.048 & 1680 \\
\hline 5 & 0.595 & 0.0025 & 87 & 0.023 & 805 \\
\hline 6 & 0.201 & 0.0016 & 56 & 0.009 & 315 \\
\hline 12 & 0.178 & 0.0029 & 106 & 0.025 & 875 \\
\hline 13 & 0.250 & & & 0.055 & 1925 \\
\hline 14 & 0.299 & 0.0145 & 508 & $0.08 t$ & 2940 \\
\hline 17 & 0.405 & & & $0.0 \pm 7$ & 1645 \\
\hline 19 & 0.257 & 0.0236 & 826 & 0.068 & 2380 \\
\hline 22 & 0.221 & $\ldots \ldots \ldots \ldots$ & $\ldots \ldots$ & 0.014 & 490 \\
\hline 25 & 0.435 & 0.0087 & $30 . t$ & 0.053 & 1855 \\
\hline 26 & 0.396 & 0.0029 & 102 & 0.027 & $9 \pm 5$ \\
\hline 43 & 0.129 & 0.0025 & 87 & 0.052 & 1820 \\
\hline 45 & 0.139 & $\ldots \ldots \ldots$ & $\ldots \ldots \ldots$ & 0.030 & 1050 \\
\hline 46 & 0.250 & & $\ldots \ldots \ldots$ & 0.039 & 1365 \\
\hline 47 & 0.259 & 0.0025 & 87 & 0.017 & 595 \\
\hline 55 & 0.507 & & $-\infty$ & & \\
\hline 60 & 0.291 & 0.0020 & 70 & 0.015 & 525 \\
\hline 33 & 0.280 & 0.0021 & 73 & 0.062 & 2170 \\
\hline 66 & 0.231 & 0.0032 & 112 & 0.043 & 1505 \\
\hline 69 & 0.426 & 0.0038 & 133 & 0.039 & 1365 \\
\hline 71 & 0.413 & 0.0059 & 206 & 0.051 & 1785 \\
\hline 81 & 0.243 & 0.0020 & 70 & 0.013 & 455 \\
\hline 90 & 0.407 & 0.0032 & 112 & 0.014 & 490 \\
\hline 92 & 0.815 & 0.0063 & 220 & 0.022 & 770 \\
\hline 93 & 0.242 & 0.0053 & 186 & 0.013 & 455 \\
\hline 601 & 0.400 & 0.0038 & 133 & 0.021 & 735 \\
\hline 604 & 0.166 & 0.0056 & 196 & 0016 & 560 \\
\hline 614 & 0.422 & 0.0033 & 115 & 0.025 & 875 \\
\hline 616 & 0.258 & $\ldots \ldots \ldots \ldots$ & $\ldots \ldots \ldots$ & $\mid \ldots \ldots \ldots \ldots$ & $\ldots \ldots \ldots$ \\
\hline 617 & 0.319 & & $\ldots \ldots \ldots$ & $\ldots \ldots \ldots . . .$. & $\ldots \ldots \ldots \ldots$ \\
\hline
\end{tabular}


PHOSPHORIC ACID.

\begin{tabular}{|c|c|c|c|c|c|}
\hline $\begin{array}{c}\text { Laboratory } \\
\text { No. }\end{array}$ & $\begin{array}{l}\text { Phosphoric } \\
\text { Acid in Soil. }\end{array}$ & $\begin{array}{l}\text { Soluble in } \\
\text { Water. }\end{array}$ & $\begin{array}{l}\text { Pounds } \\
\text { per Acre. }\end{array}$ & $\begin{array}{l}\text { So uble in } \\
\text { Citric Acid }\end{array}$ & $\begin{array}{l}\text { Younds per } \\
\text { Acre. }\end{array}$ \\
\hline & Per cent. & Per cent. & & Per cent. & \\
\hline 3 & 0.211 & trace & trace & 0.0043 & 150 \\
\hline 5 & 0.173 & trace & trace & 0.0035 & 122 \\
\hline 6 & 0.365 & 0.0006 & 21 & 0.0125 & 437 \\
\hline 12 & 0.096 & 0.0002 & 7 & 0.0032 & 112 \\
\hline 13 & 0.080 & 0.0002 & 7 & 0.0105 & 367 \\
\hline 14 & 0.115 & trace & trace & 0.0012 & 42 \\
\hline 17 & 0.157 & trace & trace & 0.0042 & 147 \\
\hline 19 & 0.166 & 0.0002 & 7 & 0.0018 & 63 \\
\hline 22 & 0.223 & $\ldots . . . . .$. & $\ldots \ldots$ & 0.0020 & 70 \\
\hline 25 & 0.221 & trace & trace & 0.0019 & 66 \\
\hline 26 & 0.153 & trice & trace & 0.0018 & 63 \\
\hline 43 & 0.110 & trace & trace & 0.0071 & 248 \\
\hline 45 & 0.085 & $\ldots \ldots \ldots \ldots$ & $\ldots \ldots \ldots$ & 0.0038 & 133 \\
\hline 46 & 0.088 & (2) & $\ldots \ldots$ & 0.0036 & 126 \\
\hline 47 & 0.292 & trace & trace & 0.0022 & 77 \\
\hline 55 & 0.464 & $\ldots \ldots$ & $\ldots \ldots \ldots$ & 0.0035 & 123 \\
\hline 60 & $0.35 \pm$ & trace & trace & 0.0016 & 56 \\
\hline 33 & 0.137 & 0.0008 & 28 & 0.0034 & 119 \\
\hline 66 & 0.579 & 00006 & 21 & 0.0039 & 136 \\
\hline 69 & 0.602 & 0.0002 & 7 & 0.0058 & 203 \\
\hline 71 & 0.307 & 0.0002 & 7 & 0.0027 & 95 \\
\hline 81 & 0.527 & 0.0002 & 7 & 0.0011 & 144 \\
\hline 90 & 0.606 & 0.0005 & 17 & 0.0031 & 108 \\
\hline 92 & 0.281 & 0.0005 & 17 & 0.0025 & 88 \\
\hline 93 & 0.772 & 0.0002 & 7 & 0.0057 & 199 \\
\hline 601 & 0.711 & 0.0007 & 24 & 00081 & 294 \\
\hline 604 & 0.301 & 0.0003 & 10 & 0.0085 & 297 \\
\hline 614 & 0.239 & 0.0005 & 17 & 0.0038 & 133 \\
\hline 616 & 0.132 & $\ldots \ldots \ldots$ & $\ldots \ldots \ldots$ & 0.0033 & 115 \\
\hline 617 & 0.333 & $\ldots \ldots \ldots$ & $\ldots \ldots \ldots$ & 0.0046 & 161 \\
\hline
\end{tabular}


It may be explained at this place that a statement in per cent. quantity up to the fourth decimal may be accepted as reliable, for the reason that in all the determinations never less than $200 \mathrm{grams}$ of soil were taken. Con-

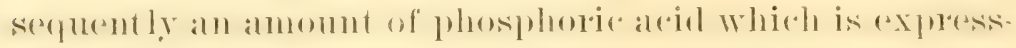
ed by even a low figure in the fourth decimal means an actual weight of magnesium pyro-phosphate that a moderately sensitive balance will easily take account of, even up to one-ten-thousandths of one per cent.

From the tables of data presented we obtain a more or less adequate understanding of the rariation in the amounts of lime, potash, and phosphoric acid present in our soils, and of the different behatrione of these elements, under the solvent action of water and citric acid, in soils from different localities. These differences indicate that these elements are contained in the soils in rarying chemical forms, to which can be due the difference in solubility. Before making further comment upon the tables of data we shall bring them together in concise averages; and at the same time we shall divide the soils examined into the two classes under which they have been considered previously, viz: Upland (mauka) soils, and lowland (makai) soils, this division being batsed npon thes signal differene in relimatic (ombitions that obtain at different elevations. The first small table gives the average of lime, potash, and phosphoric acid in the 30 type soils, as shown by the agricultural analyses:

\begin{tabular}{|c|c|c|c|c|c|}
\hline Soils. & $\begin{array}{c}\text { Type } \\
\text { Samples. }\end{array}$ & $\begin{array}{c}\text { Sub- } \\
\text { Samples. }\end{array}$ & Lime. & Potash. & $\begin{array}{l}\text { Phosphorie } \\
\text { Acid. }\end{array}$ \\
\hline & & & Per cent & Per cent. & Per cent. \\
\hline Uplands.......... & 14 & 168 & 0277 & 0.299 & 0.316 \\
\hline Lowlands............. & 16 & 192 & 0.399 & 0.377 & $0.30 t$ \\
\hline
\end{tabular}


The elements soluble in water, and in one per cent. citric acid solution, are respectively as follows:

\begin{tabular}{|c|c|c|c|c|c|}
\hline & $\begin{array}{l}\text { Soluble in } \\
\text { Water. }\end{array}$ & $\begin{array}{l}\text { Pounds } \\
\text { Per Acre. }\end{array}$ & $\begin{array}{l}\text { Soluble in } \\
\text { Citrie Acid. }\end{array}$ & $\begin{array}{l}\text { Pounds } \\
\text { Per Acre. }\end{array}$ & $\begin{array}{l}\text { Total Pounds } \\
\text { Per Acre. }\end{array}$ \\
\hline UPLANDS. & Per cent. & & Per cent. & & \\
\hline Lime.. & 0.0032 & 112 & 0.0940 & 3290 & 9695 \\
\hline Potash ......... & 0.0031 & 110 & 0.0250 & 875 & 10465 \\
\hline Phosphoric Acid.. & 0.0001 & 3 & 0.0035 & 122 & 11795 \\
\hline \multicolumn{6}{|l|}{ LowLANDS. } \\
\hline Lime. . & 0.0054 & 189 & 01330 & 4655 & 13965 \\
\hline Potash.. & 0.011 .47 & 164 & 0.6380 & 13330 & 11795 \\
\hline Phosphoric Acid. & 0.0003 & 10 & 0.0046 & 162 & 10640 \\
\hline
\end{tabular}

The "pounds per" acre" in the three columns are calculated by means of the weight of an acre of soil one foot deepe, to which msually the sample is taken, which weight is set at the average of $3,500,000 \mathrm{lbs}$. The weight is greater than this on most lowlands and less on the uplands, which contain notably more organic matter. The weight of the cubic foot of soil varies some 13 lbs.-from so lbs. to 93 lbs. for water-free material.

These estimations of solubility of the lime, potash, and phosphoric acid confirm in an ample measure our observations made mpon mpland and lowland soils in 1895 and 1896. In speaking of the lime contents of the upper and lower lands it was said in 1895 "the lime present in the upland soils has been, previous to cultivation, prac. tically the same, which is shown by analyses of virgin and cropped soils, and comparison of the upland virgin soils with the lowland soils;" but "as the lime, being in a more or less soluble state, was washed out and down into the lowlands, or into the sea, by the heary rains." The lime soluble in water, we see, is $189 \mathrm{lbs}$. in the low- 
lands, against 112 lbs. in the uplands. The same is found under the action of the citric acid, where the upland

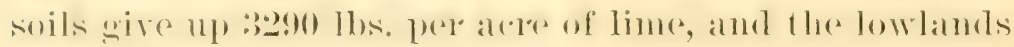
no less than 4655 los. per acre, in 24 hours to the action of citric acid. The observations on the solubility of the potash in the upper and lower lands are also in agree. ment with previous findings. In the matter of the phosphoric acid the results are even more remarkable in the Way in which they support previous conchusions upon this borly and its state of insolubility. In our reports of 1895 and 1896 it is said "the phosphoric acid in our soils appears to be locked up so secmely by the iron and other compoumds that plants use it with difficulty." In the above tables it is seen that the phosphoric acid soluble in water in the lowlands is $10 \mathrm{lbs}$. per acre, and in the uplands 3 lbs., which, practically speaking, means none at all, whilst the amount dissolved by the citric acid is relatively very small.

Br far, the most striking result from the action of an $1 \%$ solution of citric acid upon the soil is the enormons proportion of the lime, and also of the potash, dissolved. 'The lime found by the agricultural analyses in the upland soils was 9695 lbs. per acre, and of this amount 3290 lbs., or $30 \%$, were dissolved by the acid in 24 hours. In the lowland soils the lime pel acle was 13,965 lbs., and the citric acid took ont 4655 lbs., or about $30 \%$ of the total found in the soil by the agricultural analyses. The potash dissolved was also a rery large proportion of the whole. Yet the action of an $1 \%$ citric acid solution is much less than the action of solvents that are used by chemists in estimating the so-called "amount of available elements."

'The question suggested by our results with citric acir, 
and more strongly reiterated by other results that have been published, is How much nearer are we brought to an nuderstanding of the actual avalability of the elements -their relation to the demands of the plant-by the use of citric acid in $1 \%$ solution, as compared with the results of the agricultural analyses obtained by the use of concentrated hydrochloric acid? 'The latter mineral acid, in 10 hours, upon the water bath, dissolved out all the lime which, it has been said, "can ever become soluble;" and yet a cold, $1 \%$ solution of citric acid, which is the solvent most accepter for determining the amount of the elements "immediately arailable," takes out $30 \%$ of the "total lime" in 24 hours.

The "absolute analyses" of soils giren in the first part of these investigations, with the examination of the "insoluble residue" of the soil, after digestion with concentrated hydrochloric acid, afford notable light on the question of solubility of the comstituent compounds of soils. In the "insoluble residne" of Hawaiian soils we found $1.02 \%$ of lime, which was left after the action of concentrated hydrorhloric acid, and the repeaten artion with a new quantity of the acid. Consequently the "absolute analysis" of the soil found $0.746 \%$ of lime, instead of $0.342 \%$, recorded by the usual agricultural analysis. It is thus seen that the hydrochloric acid does not take out quite one-half of the lime present in the soil. These data afford, as said, notable light upon the state of solubility of om soils, and upon their mote of structure, all of which indications are invaluable in a complete study, and accentuate the fundamental prin. ciple of comparative solubilitics which dominates all structure in the mineral, vegetable, and animal kingloms. The data, however, do not help us in estimating the lime, 
potash and phosphoric acid "immediately available" to the growing plant.

Knowing the total lime actually contained in the soil, as shown by the "absolute analysis," and the proportion of that total fomml soluble in comerentrated hydrochlorite acid after digesting 10 hours upon a water bath, we went on to the examination with an $1 \%$ solution of citric acid. The citric acid solution, however, exercised a solrent action in 24 hours equal to one-third of the solvent power of the hydrochloric alede, dissolving ont one-seventh of the total lime found by absolute analysis, and in the short period of one day. In this action we do not find anything, in point of degree, corresponding to the pro cesses which go on in Nature; or in the results of this action, any indication of the proportion of plant food that is actually arailable. But for the grand principle of differential solubility obtaining in all matter, the citric acid would have taken all the lime out of the soil in probably less than six days. There is no relation between these results and the amount of plant food remored from the soil by crops-which action of crops, however, as we shall show later, also bears no constant relation to the ratio of plant food depletion in soils under cultivation, and therefore cannot be taken as a guide in the matter of fertilization, or restoring the lost elements.

Of comse, it has not been claimed that the action of an $1 \%$ solution of citric acid corresponds to the action of solvent agents operating in Nature, but the results of its action have been taken to furnish an estimate of the available plant food in soils, and we find that it has but litte more meaning in surh respect than the hydrochlorie acid used in the common analyses.

What the continued action of an $1 \%$ solution of citric 
acid upon soils might result in is exemplified by results obtained by us of its action on lavas. A weighed piece of solid lava was put into a bottle, and $300 \mathrm{cc}$. of an $1 \%$ solution of citric acid added, the acid being renewed every fourth day on account of its liability to ferment. Another weighed piece of the same lava, but in a state of decomposition, from simple weathering, was put into a second bottle and treated in the same way with the citric acid. At the end of three months the weathered lava was totally disintegrated, and chiefly in solution. The solid lava, which weighed 29.140 grams on Jan. 27, after nine months action of the citric acid, weighed only 14.63 grams, the residue being left in such a soft state that the thumb nail penetrated it easily.

In considering a solvent, however, which is selected with a view to approximating the action of the solvent agents operating in Nature, some attention should be given to the organisms of plants, and their sensibility to the action of acids. An extensive series of observations upon the "Relative Sensibility of Plants to Avility in Soils" was conducted by the writer which furnished data, a part of which will serve the present purpose. The following data set forth the effect of applying to plants growing in tubs a volume of water equal to the amount that the soil was just (alpable of absorbing and holding, which amount was $48 \%$ on the weight of the soil. This water contained one-tenth of one per cent. of citric acid. Every fourth day the weights of the tubs were taken, and the anount of evaporation found, when enough watel was again added to bring up the volume to the maximum absorptive power of the soil. With the water added, enough citric acid in solution was also added to make the total water in the soil every fourth day equal to one- 
tenth of one per cent. solution of the acid. 'The acid was applied with the greatest care by use of a large pipette, thus making sure that the same volume was delivered to each of the 18 plants under treatment. We give the results obtained by the use of one strength of acid which will be enough for the present purpose. Observations with different strengths of acid were made, the results of all which have already been published. 'The following data are the record of the action of a solution of citric acid, one-tenth of one per cent. in strength:

\section{A. CRUCIFERA.}

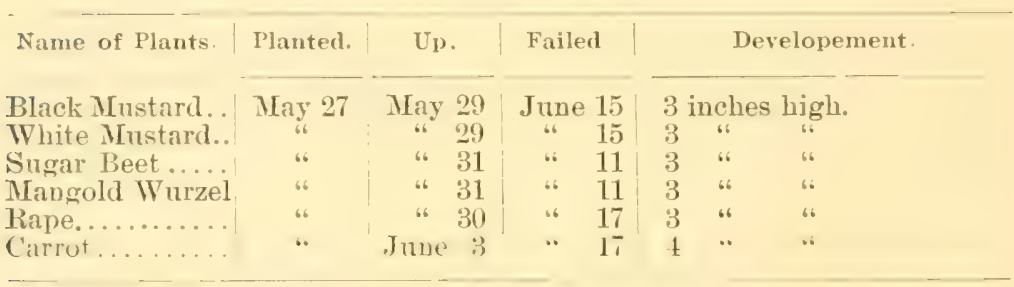

B. LEGUMINOSAE.

\begin{tabular}{|c|c|c|c|c|}
\hline Name of Plants. & Flanted. & $\mathrm{Up}_{\mathrm{p}}$ & Failed. & Development. \\
\hline $\begin{array}{l}\text { White Lupine. } \\
\text { Cow Bean...... } \\
\text { Horse Bean .... } \\
\text { Winter Vetch.. } \\
\text { Crimson Clovr.. } \\
\text { Alfalfa.......... }\end{array}$ & $\begin{array}{c}\text { May } 27 \\
6 \\
6 \\
6 \\
6 \\
\text { "6 }\end{array}$ & $\begin{array}{cc}\text { May } & 30 \\
\cdot 6 & 30 \\
\text { June } & 3 \\
\text { May } & 31 \\
\text { "6 } & 30 \\
\text { ". } & 29\end{array}$ & $\begin{array}{rr}\text { July } & 16 \\
\text { Aug. } & 31 \\
\text { "6 } & 12 \\
\text { July } & 9 \\
\text { June } & 17 \\
\text { "6 } & 15\end{array}$ & 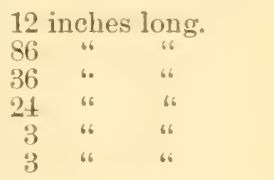 \\
\hline
\end{tabular}

\section{GRAMINAE.}

\begin{tabular}{|c|c|c|c|c|}
\hline Name of Plants. & Planted. & Up. & | Matured. & Development. \\
\hline 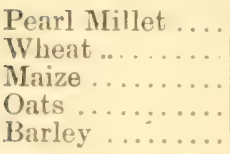 & $\begin{array}{c}\text { May } 27 \\
6 \\
6 \\
6\end{array}$ & $\begin{array}{c}\text { May } 30 \\
6 \\
6 \\
6 \\
6\end{array}$ & $\begin{array}{c}\text { Matured. } \\
\text { Failed } \\
6 \\
6 \\
6\end{array}$ & $\begin{array}{l}49 \text { inches ind Sound Seeds. } \\
15 \text { inches long. } \\
42 \text { inches long; no Seed } \\
8 \text { inches long. } \\
8 \text { inches long. }\end{array}$ \\
\hline
\end{tabular}


These results have a great ralue in indicating the "relative sensibility" of our common agrierultural plants to soil acidity. It is seen that all the crucifera, and the clovers succumb at once to the acid; but certain legumes and graminae attain a notable growth. Only the pearl millet however, reaches a normal development, forming seed of excellent appearance. These results show rery clearly that in using a solution of citric acid of one-tenth of one per cent. in strength for estimating the available plant food in soils, we are dealing with a solvent whose action cannot correspond to anything operating in Nature.

The considerations that we have enumerated, all of which have assisted in leading to the conclusion that the use of an $1 \%$ solution of citric acid does not assist us very materially more than concentrated hydrochloric acid in actually reaching a duplication of the measure of solvent activity proceeding in Nature; nor thus, in estimating the proportion of the soil elements that are immediately available as plant food-these considerations, we repeat, have caused us to try to follow, in thought, more closely the course of Nature's operations; the continuous but slow processes which mark her modes of action, and to endeavor to come somewhat more approximately, in our laboratory observations, mon the plane of action wherein the processes of the field are going on. We are quite aware that we cannot strictly duplicate the proceerlings of Nature. By watching her ways, however, and adjusting on methods of observation to the modes which she appears to use, we may work towards results apparently more comparable, and which may actually guide us in dealing with the practical ques. tions of the field. 
The lesults obtained by the use of an one per cent. solution of citric acid upon soils led us into a line of observations, in which menlier solvents were userl, but their action extended over a period of week instead of hours. By this mode of treatment we expected, at least, to come nearer to what is taking place in the field.

After much consideration, and sereral preliminary con. trol tests, a method was decided upon that we shall speak of with some detail.

The minciple of the method was the use of solvents of small, and also different degeres of strength; the lenewal of the solvent every fourth day, with the continuance of its action orer a considerable period of time, and the examination of the results at definite intervals along thia coul'se of time.

Some Prelnmary 'Tests.-In considering modes of carrying out these Time Experiments, as they had been named by us, the finst plan involved the use of lange funnels with ground tops and glass plate corers, and the corking of the stem of the fumnel. The soil was to be put into the funnel and the solvent added. Erery fourth day, fire cubic centimeters of the solvent were to be drawn off and tested with a standardized alkali, and the necessary

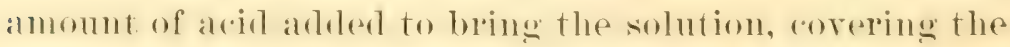
soil, up to precisely its original strength. The portion of solution drawn off at the bottom of the fumnel, was found, upon comparison, to have a less degree of acidity than another portion that was taken with a pipette from the liquid above the soil in the fumnel. 25ec from above the Soil in fimnel...... 23.5ec. Na OH.

$25 \mathrm{ec}$ drawn off at bottom of funnel

$=1+5 \mathrm{ec}$

These tests showed that at the end of seren days the acid contained in a solution, added to a soil kept at rest 
in a funnel, had not become equally distributed and nentralized, consequently this mode of treatment could not be used.

Further tests furnished results showing the different action of the same solvent under different conditions. A given volume of the solvent was added to a given weight of soil, and the vessel kept still for seven days. An equal volume of the solution was added to an equal weight of the soil, and the bottle shaken gently every fifteen minutes during the day portion of 24 hours.

\footnotetext{
25ce. of original solution ............. = $362 \mathrm{cc} . \mathrm{Na}$ OH.

$25 \mathrm{cc}$ of solution after standing 7 days .......

$25 \mathrm{cc}$. ef solution after shaking 24 hours ..... $=12.4 \mathrm{cc}$. "
}

These observations show, in general, that the action resulting from the use of a solvent is largely controlled by the mode of its use. The former test showed why, for the purpose of these Time Experiments, a solvent could not be used upon soil in a funnel, or other vessel, at rest. Further, and repeated, tests have shown, with equal clearness, that by shaking the vessel containing the soil and solvent, which is the only mode of securing an uniform distribution and action of the solvent, the re. sults of the action will be in large measure proportionate to the vigor of the shaking.

As a result of these simple preliminary tests, a mode of treatment was adopted which can be stated as follows: Exactly 200 grams of soil were put into the orelinaly two litre acid bottles, having ground glass stopper's, and $200 \mathrm{cc}$. of the solvent added. This volume was found to be just about enough to saturate and immerse the soil, without any great excess of the solvent solution being present, which was guarded against. 
Twenty bottles were taken and charged with 200 grams of soil and $200 \mathrm{cc}$ of solvent, as already stated. 'Ten of these bottles were given to observations on mpland (manka) soils; and the remaining ten bottles to corresponding observations on lowland (makai) soils.

Each series of ten bottles was further divided into two groups of five bottles each. The one group was to fur. nish data seetting forth the lesults of the continned artion of an one-tenth of one per cent. solution of acid, and the second group of an one-fiftieth of one per cent. solution of acid upon the same soil. The four groups, of five bottles each, were thus to furnish results from the two different strengths of arid upon the "upland" and "lowland" soils. One bottle from each of the four groups, containing five bottles earh, was selected for testing and controlling the acidity of the bottles in the four groups. This was done in orler to aroid the necessity of testing the remaining acidity of the solution in all the twenty bottles at the intervals decided upon, which was every fourth day, and was based on the supposition that if 200ec. of solution of either of the stated strengths, were added to duplinates of 200 grams of soil put into fire bottles the action of the acid, and the remaining acidity, would be the same in each bottle, providing all the bottles were shaken, and otherwise treated, the same. The grouping of the series may be seen more clearly as follows: 


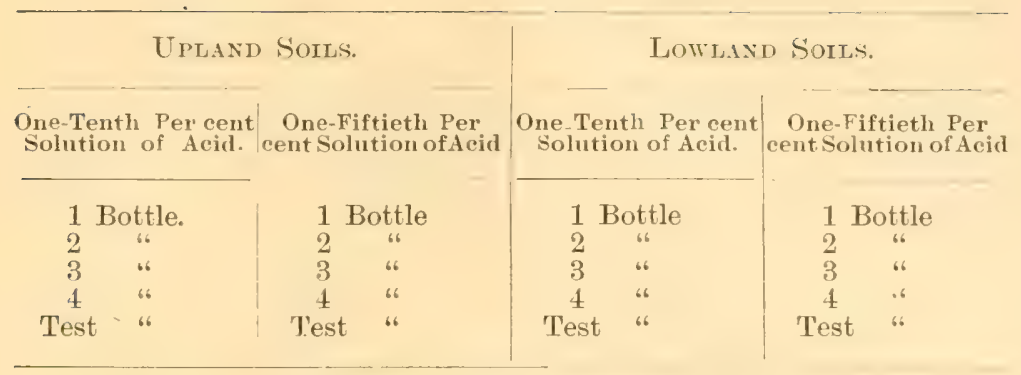

These "Time Experiments" were conducted with citric acid as the solvent, in order that the results should be comparable with the series of results obtained with the one per cent. solution of citric acid, that have already been given.

The control of the acidity of the solutions was made by use of an 1-500 normal solution of sodic hydrate. Every fourth day 25ce. of solution was drawn with a pipette from each of the four "test bottles" and the remaining acidity of the solution determined; when enough citric acid was added to restore the acidity of the solutions in each bottle in all the groups to the original strength. The following table shows the variation of behaviour of the acid solutions during the intervals of four days: 


\begin{tabular}{|c|c|c|c|c|c|c|c|c|c|}
\hline \multirow{2}{*}{\multicolumn{2}{|c|}{ Date. }} & \multicolumn{4}{|c|}{ UPLAND SOIT,S. } & \multicolumn{4}{|c|}{ LOWLAND SOILS. } \\
\hline & & \multicolumn{2}{|c|}{$\begin{array}{l}\text { One-tenth } \\
\text { Solution. }\end{array}$} & \multicolumn{2}{|c|}{$\begin{array}{l}\text { One-fiftieth } \\
\text { Solution. }\end{array}$} & \multicolumn{2}{|c|}{$\begin{array}{l}\text { One-tenth } \\
\text { Solution. }\end{array}$} & \multicolumn{2}{|c|}{$\begin{array}{l}\text { One-fiftieth } \\
\text { Solntion. }\end{array}$} \\
\hline Original & Solutions & $184.7 \mathrm{ecol}$ & kali & $36.2 \mathrm{ce}$ & lkali & $184.7 \mathrm{ce}$ a & alkali & i $36.2 \mathrm{cc}$. : & $1 \mathrm{kali}$ \\
\hline January & $25 \ldots \ldots$ & 13.0 се. & $\cdot$ & $9.4 \mathrm{ce}$ & " & $5.2 \mathrm{cc}$ & " & 7.1 се. & \\
\hline & 29 & 16.7 се. & $"$ & $9.3 \mathrm{ce}$ & .6 & $7.5 \mathrm{cc}$ & " & $2.5 \mathrm{cc}$ & \\
\hline February & y 2 & $29.3 \mathrm{cc}$ & " & $16.7 \mathrm{ce}$ & " & $18.8 \mathrm{ce}$ & " & $5.0 \mathrm{ce}$. & "“ \\
\hline & 6 & $39.2 \mathrm{cc}$ & ". & $12.9 \mathrm{cc}$ & 6 & $25.5 \mathrm{cc}$ & " & $4.9 \mathrm{cc}$. & ." \\
\hline " & 10 & $39.0 \mathrm{cc}$. & $"$ & $9.0 \mathrm{ce}$ & "6 & $20.0 \mathrm{ce}$ & "“ & $4.4 \mathrm{ce}$. & " \\
\hline .. & 15) & 501,0 ce. & " & $9.0 \mathrm{ec}$ & " & $111.0 \mathrm{ec}$ & ". & 3.11 c ce. & ". \\
\hline ". & 19 & $62.5 \mathrm{ce}$ & .. & $15.0 \mathrm{cc}$ & 16 & $30.0 \mathrm{cc}$ & ، & $5.0 \mathrm{cc}$. & "“ \\
\hline ". & 23 & 50.9 (ес. & ". & $10.7 \mathrm{ec}$ & ". & 25.0 ece & "“ & $4.3 \mathrm{ce}$. & "* \\
\hline " & 27 & 11110.0 eе. & ". & $18.2 \mathrm{ce}$ & .6 & $30.0 \mathrm{ce}$ & " & 4.2 ece. & ". \\
\hline March & 3 & $93.7 \mathrm{cc}$ & .. & $20.5 \mathrm{cc}$ & 6 & $43.7 \mathrm{cc}$ & "6 & $2.5 \mathrm{cc}$ & "“ \\
\hline " & 8 & $720 \mathrm{ec}$ & ". & $8.7 \mathrm{ce}$ &. & $132 \mathrm{ce}$ & ". & $1.2 \mathrm{coc}$. & " \\
\hline " & 12 & $80.0 \mathrm{cc}$ & "6 & $6.2 \mathrm{cc}$ & " & $27.5 \mathrm{cc}$ & " & $2.0 \mathrm{cc}$ & " \\
\hline •. & 16. & $58.0 \mathrm{ce}$ & ". & $15.0 \mathrm{cc}$ & " & $28.7 \mathrm{cc}$ & " & $1.7 \mathrm{cc}$. & "“ \\
\hline •. & 20 & $42.5 \mathrm{ce}$. & “. & $12.0 \mathrm{ce}$ & ". & $25.1) \mathrm{ce}$ & ". & $20 \mathrm{ce}$. & .• \\
\hline "“ & 25. & $75.0 \mathrm{cc}$. & ". & $7.5 \mathrm{cc}$ & " & $25.0 \mathrm{cc}$ & " & $1.2 \mathrm{cc}$. & "“ \\
\hline ". & 29 & $21.2 \mathrm{ec}$ & " & $17.5 \mathrm{ec}$ & $"$ & $15.0 \mathrm{ce}$ & “. & $1.5 \mathrm{ec}$. & .. \\
\hline dpril & 2 & 87.2 ce. & ". & $10.0 \mathrm{ec}$ & " & $18.5 \mathrm{ce}$ & ". & $1.5 \mathrm{coc}$. & ". \\
\hline & 6 & $30.0 \mathrm{cc}$. & " & $17.5 \mathrm{cc}$ & "6 & $37.5 \mathrm{cc}$ & $"$ & $3.7 \mathrm{ce}$. & "6 \\
\hline " & 10 & $72.5 \mathrm{cc}$. & " & $15.0 \mathrm{cc}$ & " & $35.0 \mathrm{cc}$ & " & $3.0 \mathrm{ce}$. & " \\
\hline ". & 14 & rifi.z ece. & ". & $15.0 \mathrm{ce}$ & " & $43.7 \mathrm{cc}$ & " & $+2 \mathrm{ce}$ & ". \\
\hline ". & 19. & 61.2 ee. & " & 12.5 ee & " & $33.7 \mathrm{ce}$ & " & $4.5 \mathrm{ce}$. & "“ \\
\hline
\end{tabular}

The first line of each of these four columms shows the number of cubic centimeter of the alkali solution that were required to neutralize $25 \mathrm{ce}$. of the original acid solutions used as solvents. The lemaining figures in eatro column show the number of cubic centimeter of alkali required to neutralize 25ce. of the acid solutions at the intervals stated. The total amounts of crystalline citric acid applied to the 200 grams of soil in each bottle in the respective groups during the time between January 21 and April 19 were as follows:

\begin{tabular}{|c|c|c|}
\hline Soils. & Solution Applied. & Citric Acid Applied. \\
\hline $\begin{array}{l}\text { Upland, One-Tenth Solution ........ } \\
\text { Lowland, One-Tenth Solution . .... } \\
\text { Upland, One-Fiftieth Solution. ... } \\
\text { Lowland, One-Fiftieth Solution .... }\end{array}$ & $\begin{array}{l}550 \mathrm{ce} \\
550 \mathrm{ec} \\
600 \mathrm{ec} \\
600 \mathrm{ec}\end{array}$ & $\begin{array}{l}2.94 \text { Grams } \\
3.60 \\
0.54 \\
0.74\end{array}$ \\
\hline
\end{tabular}


On Jamuary 21 the experiment was begun with $200 \mathrm{cc}$. of solution in each bottle. The adding of citric acid every fourth day, even in the most concentrated solution, brought up the volume to $550 \mathrm{cc}$. and $600 \mathrm{cc}$. respectively. To guard against the action of this increased volume a portion of the nearly neutralized solution was remored from the soil in the bottles, thus keeping the rolume more closely to the original amount. The removed portions were preserved and added finally to the whole when filtered off from the soil at the time of analysis.

Bemaviodr of the Citric Aord.-In examining the columns which state the measure of neutralization of the acid in the solution, as indicated by the amount of alkali required to neutralize the remaining ardity, a very great variation appears between the intervals in the amounts of acid unneutralized. In the first column it is seen that at the end of one interval only 13ce. of alkali were necessary to nentrality; at the end of another interval $100 \mathrm{cc}$ of alkali were taken to neutralize the acid remaining in the solution. This variation appears along the column, and in all the columns. We became persuaded that this varying behaviour of the solvent between the intervals was due to the fermentation of the citric acid, and two control tests were begun in order to observe the mode and measure of the fermentation. These tests were made by placing 200 grams of soil in each of two bottles the one containing upland, and the othel lowland soil, and adding $200 \mathrm{cc}$ of the $1-10$ solution of citric acid, and renewing the acid at the intervals when new acid was added to the other groups of bottles. The acid was added in these tests through separatory funnels, as the bottles were sealed and connected with receiring flasks containing lime water, the latter having to take care of 
the carbonic acid, if fermentation proceeded in the bottles containing the soil and solvent. While waiting for some indications of fermentation to be given by these tests, a very excellent observation was made by First Assistant Crawley. At the time of titrating with alkali solution, at the end of an interval, Mr. Crawley placed a portion of solution which was notably acid, over a burner and heated gently for several minutes; after cooling, the solution was no longer acid, but even reacted alkaline, showing that the acidity was due wholly to carbonic acid, no citric acid being present.

That observation led us to examine and find out whether it was the citric acid itself, or citrates formed with the soil bases, which had undergone fermentation?-a question suggested to the writer by previous observations. The examination and its results are found in the following data, the upland 1-10 examples being used for the examinations.

April 2, 10 ocl., 25ce. solution required st.2ce. of 5ัँं alkali to neutralize the acidity, due wholly to carbonic acid. At this time citric acid was added to the solution in the bottle which was equal to $100 \mathrm{ce}$ รर̃ं alkali. Therefore, at $10 \mathrm{ocl}$. the acidity of the solution may be expressed as follows:

Acidity due to Carbonic Acid ....................... 87.2 Acidity due to Citric Arid ..................... 100.0

'Total Acidity of the Solution. . . . . . . . . . . .

April 2, 10 ocl. Acidity due to Citric Acid ....... $=100.0$

3 ocl. Acidity due to Citric Acid ........... $=16.0$

Decrease in Acidity due to Citric Acid . ......... $=\overline{84.0}$

April 2. 10 ocl. Acidity due to Carbonic Acid...... $=87.2$

3 ocl. Acidity due to Carbonic Aeid ........ $=101.5$

Increase in Acidity due to Carbonic Acid......... $=\overline{14.3}$

April 3, 9 ocl. A. M. 'Total Acidity ............ $=35.5$ wholly due to Carbonic Acid. 
In the first place, it is seen that of the 100 parts of citric acid added to the soil and solution at 10 ocl., 84 parts had disappeared by 3 ocl., or in 5 hours. That these 84 parts of citric acid had not fermented, furnishing carbonic acid, is indicated by the fact that the carbonic acid had increased from 87.2 parts to only 101.5 parts, or by merely 14.3 parts; showing that the citric acid had largely formed citrates with the soil bases. 'The inclease of 14.3 parts of carbonic acid shows, however, that either a portion of the unfixed citric acid, or of the formed citrates, had fermented, thus yielding the increase of carbonic acid. But, bearing in mind the short period of five hours that was required to fix 84 parts, out of 100 parts of citric acid, and further, the large amount of acid found in the solutions several days after acid had been added, it is indicated that the carbonic acid is derived from the fermentation of the citrates, rather than of the citric acid; although other observations have shown how easily citric acid, in dilute solutions, undergoes decomposition when not in contact with a soil. By the reduced amount of carbonic acid found in the solution on the next day, April 3, it is shown that a part of it had also been fixed by the bases; and this fixing of the carbonic acid is uniformly observed to occur in greater proportion in the neutral lowland soils than in the upland soils, which latter we have found to be fire-fold more acid than the lowland soils.

The observations upon methods that have just been recorded indicate how abstruse must be tine processes operating in Nature, and how far these are, at present, beyond our understanding. Te set out to observe the action of citric acid, as a solvent, upon our soils: The have observed that whilst a solvent action was primarily 
caused by the citric acid, the continnance of the action was due to the secondary action of carbonic acid which resulted from the decomposition of the citric acid. How much of the following results is directly due to citric and carbonic acids respectively, we, at present, cannot say; but, indirectly the whole may be ascribed to citric acid.

Results of the "The Experments" with Citric Acid.We shall now give the results of the action of the different strengths of solutions of citric acid upon the upland and lowland soils covering the given perions of time, and shall append the results of the action of uater alome, which was also observed, in order that we may approach more nearly to the precise action of the acid.

\section{UPLAND SOILS.}

ACTION OF ONE-TENTH PER CENT SOLUTION OF CITRIC ACID.

\begin{tabular}{|c|c|c|c|c|c|c|}
\hline Date of Analysis. & Time of Action. & $\mathrm{CaO}$ & $\mathrm{K}_{2} \mathrm{O}$ & $\mathrm{P}_{2} \mathrm{O}_{5}$ & $\begin{array}{lll}\mathrm{Fe}_{2} & \mathbf{A l}_{2} & \mathrm{O}_{6}\end{array}$ & Si O \\
\hline & & $\begin{array}{c}\text { Per } \\
\text { cent. }\end{array}$ & $\begin{array}{c}\text { Per } \\
\text { cent. }\end{array}$ & $\begin{array}{l}\text { Per } \\
\text { cent. }\end{array}$ & Per cent. & $\begin{array}{c}\text { Per } \\
\text { cent. }\end{array}$ \\
\hline Febuary $2 \ldots$ & 12 days $\ldots$ & & & $\begin{array}{l}.0008 \\
0008\end{array}$ & & \\
\hline April $\quad 9$ & 78 “ & .02 & .018 & 0019 & & \\
\hline Juve & 103 6 & .0202 & .0175 & .0028 & .0878 & 0046 \\
\hline
\end{tabular}

ACTION OF ONE-FIFTIETH PER CENT SOLUTION OF CITHIO AOID.

\begin{tabular}{|c|c|c|c|c|c|c|}
\hline Date of Analysis. & Time of Action. & \multirow{2}{*}{$\begin{array}{c}\mathrm{CaO} \\
\text { Per } \\
\text { cent. }\end{array}$} & \multirow{2}{*}{$\begin{array}{c}\mathrm{K}_{2} \mathrm{O} \\
\text { Per } \\
\text { cent. }\end{array}$} & \multirow{2}{*}{$\frac{\mathrm{F}_{2} \mathrm{O}_{5}}{\text { Per }}$} & \multirow{2}{*}{$\frac{\mathrm{Fe}_{2} \mathrm{Al}_{2} \mathrm{O}_{6}}{\text { Per cent. }}$} & \multirow{2}{*}{$\begin{array}{l}\text { Si } O_{2} \\
\text { Per } \\
\text { cent. }\end{array}$} \\
\hline & & & & & & \\
\hline Febuary 2.. & 12 days & .0097 & & .0008 & & ... \\
\hline 6 23. & 33 & .0136 & 0223 & .0009 & & $\ldots \ldots$ \\
\hline $\begin{array}{l}\text { April } \\
\text { Jume }\end{array}$ & 78 & .0129 & 0146 & 0011 & .0279 & $00+1$ \\
\hline June & . . . & .0125 & 0186 & .0015 & .0268 & $.00 \pm 1$ \\
\hline & 120 days $\ldots$ & $\begin{array}{l}.0032 \\
.0097\end{array}$ & $\begin{array}{l}.0033 \\
.0149\end{array}$ & $\begin{array}{l}.0001 \\
.0007\end{array}$ & .0231 & 0046 \\
\hline
\end{tabular}


LOWLAND SOILS.

ACTION OF ONE-TENTH SOLUTION OF CITRIO AOID.

\begin{tabular}{|c|c|c|c|c|c|c|}
\hline Date of Analysis. & Time of Action. & $\mathrm{CaO}$ & $\mathrm{K}_{2} \mathrm{O}$ & $\mathbf{P}_{2} \mathrm{O}_{5}$ & $\mathrm{Fe}_{2} \mathrm{Al} \quad \mathrm{O}_{6}$ & $\mathrm{Si} \mathrm{O}_{2}$ \\
\hline & & $\begin{array}{l}\text { Per } \\
\text { cent. }\end{array}$ & $\begin{array}{l}\text { Per } \\
\text { cent. }\end{array}$ & $\begin{array}{l}\text { Per } \\
\text { cent. }\end{array}$ & $\begin{array}{l}\text { Per } \\
\text { cent. }\end{array}$ & $\begin{array}{l}\text { Per } \\
\text { cent. }\end{array}$ \\
\hline February 2. & 12 days..... & .0175 & .0203 & .0007 & - & \\
\hline April $\quad 9$. & 78 " & $\begin{array}{r}.0400 \\
0221\end{array}$ & .0291 & .0010 & .0527 & 0007 \\
\hline June & 103 & .0234 & .0207 & .0018 & .0288 & 0067 \\
\hline
\end{tabular}

ACTION OF ONE-FIFTIETH PER CENT SOLUTION OF CITRIC ACID.

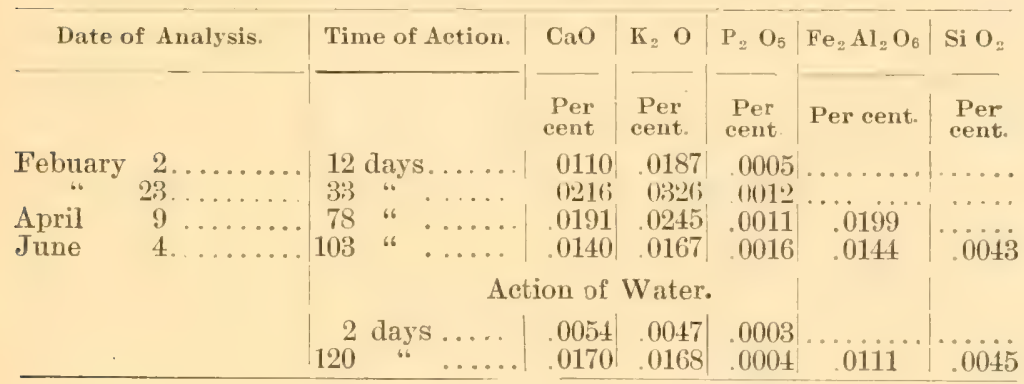

In the first place, it is seen, in general, how completely the behaviour of the upland and lowland soils is in agreement with all comparative observations previously re. corded. Throughout, and under the several actions of water, one-fiftieth, and one-tenth per cent. solutions of citric acid, more lime and potash is found soluble in the lowland than in the upland soils. This is due, as we may again explain, to the greater acidity of the upland soils. This greater acidity, which has already been said to be five-fold the acidity of the lowland soils, has been, and is still, constantly exercising a higher solvent alction upon the upland soils, and the greater rainfall on the high lands, which is the cause of the greater acidity, has washed down to lower lands, or into the sea, the lime and potash as they were brought into solution. Con- 
sequently the weak acid solutions used in the laboratory fo not find as much of these elements in the soils from above as below, because they have been removed by natural action. On the other hand, fully double the amount of iron and alumina are taken out of the upland soils that the weak acids find soluble in the lowlands. And in the mpland sols is found just twiere the proport ion of ferrous iron that onr method could detect in the lowland samples. 'This confirms our remarks in last year's report concerning the action of the excess of organic matter in the mplands in reducing the iron. "The soil, covered and filled with regetation, the result of excess of rainfall, has caused the iron to give up a part of its oxygen;" and in the first part of these investigations were confirmed other remarks in the same report, viz: "the low iron oxide unites with mineral acids in the soil, forming salts, actually poisonous to plant life." 'The examination of soils, sub-soils, and given decomposition products of lava from, and near by, certain so-called "poisoned spots" showed the presence of notable amounts of these low oxide of iron compounds.

Attention is called to the behaviour of the soils and solvents, which is brought to riew by the third series of analyses recorded on April 9. In the first place, it is seen that on Feb. 23 the proportions of lime and potash found in solution are quite double the amounts noted on Feb. 2, and this is seen uniformly in all the series. The analyses of April 9, at the end of 75 days, present a complete change in the results of the solvent action of the solutions. The lime and potash found soluble on Feb. 23 had largely reverted to a state of insolubility, and this reversion continued to take place up to the time of the last analyses on .June t, at the end of 103 dars. That 
there was no accident or error in the observations is attested by the uniform operation of the change throughont all the series.

In explanation of the reversion of a part of the dissolved elements to a more insoluble state, we shall relate the behaviour of the soils and solvents placed in the two closed bottles for the purpose of controlling the fermentation that might go on. Eight weeks after these fermentation-control tests were started, a strong fermentation set in, which was indicated by the foaming of the solution in the bottles, and the carbonic acid gas given off, which passed over into the receiver containing lime water. Up to this time the fermentation had been small and slow, and very little carbonic acid had been released. The acid given off at the time of this riolent fermentation was enough to form a notable weight of carbonate of lime. Well, a corresponding fermentation took place in the series of bottles that were standing for analysis. In these bottles the fermentation did not appear to proceed so violently as in the fermentation-control bottles; but that may have been due to the former not having been firmly closed, whereby the anbonic ar.id escaped as it formed. At the time of the analysis of the third series on April 9, the soils and solutions had an actually rotten odor, showing that a low, destructive fermentation had gone on. A reddish-yellow scum was left on the insides of the bottles, the result apparently of the lecomposition of the iron compounds in solution. It is strougly indicated that the acute fermentation was connected with the additions of citric arid; because two other bottles containing the same portions of the same soils, to which only water was added every fourth day, at the intervals when citric acid solution was added to 
the other series, were perfectly sweet, and remained swert, and without the indieations of much formentation, at the end of a period of 120 days. The reversion then, of a palt of the previously dissolved elements took plare at the time of the strong fermentation observed within the bottles, and was due to the carbonic acid given off by the decomposition of the citrates, and probably of some of the organic matter in the soils.

Conceroning the actual amount of lime and potash fomm in the acid solutions at the end of 103 days, it is seen, by returning to the last tables, that there is less of these two alements in the one-fiftieth per cent. solution of ritric acid than was taken out by the water alone. The fermentation of the citrates, and the carbonic acid produced, rendered the soil as a whole, less soluble in water than it was naturally. The continued adlition of dilute ritric acid, however, while it rendered the soil as a whole less soluble in water, acted upon the constituents, causing a notable change in the way in which they behaved towards an one per cent. solution of citric acid as compared with their behaviome moler the artion of the same strength of acid upon the natural soil. This is shown by the analytical results of the action of the one per cent. citric acid upon the natural soils, and upon these soils at the end of their treatment with the weak solutions of citric acid after a period of 103 days:

A-represents the amount of the elements dissolved by the one per cent. citric acid out of the natural soil.

B-the amount of the elements dissolved by the same strength of acid ont of the soils that had been acted upon by an one-tenth per cent. solution of citric acid for the period of 103 days. 


\begin{tabular}{|c|c|c|c|c|c|c|c|c|}
\hline \multicolumn{3}{|c|}{ Soils. } & $\mathrm{CaO}$ & $\mathrm{K}_{2} \mathrm{O}$ & $\mathrm{P}_{2} \bigcap_{5}$ & {$\left[\begin{array}{ll}\mathrm{Fe}_{2} & \mathrm{O}_{3}\end{array}\right]$} & $\mathrm{Al}_{2} \mathrm{O}_{3}$ & $\mathrm{Si} \mathrm{O}$ \\
\hline & & & $\begin{array}{l}\text { Per } \\
\text { cent. }\end{array}$ & $\begin{array}{l}\text { Per } \\
\text { cent. }\end{array}$ & $\begin{array}{c}\text { Per } \\
\text { cent. }\end{array}$ & $\begin{array}{c}\text { Per } \\
\text { cent. }\end{array}$ & $\mid \begin{array}{c}\text { Per } \\
\text { cent }\end{array}$ & $\begin{array}{l}\text { Per } \\
\text { cent. }\end{array}$ \\
\hline Upland & ..... & A & 0.1110 & 002600 & $\begin{array}{lll}0 & 0037 \\
0 & 0000\end{array}$ & 0.421 & 0.222 & $\begin{array}{ll}0 & 199\end{array}$ \\
\hline & & B & 0.1268 & 003030 & 00092 & 1379 & 0.698 & 0.071 \\
\hline Lowland & 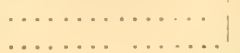 & $\begin{array}{l}\mathrm{A} \\
\mathrm{B}\end{array}$ & $\begin{array}{ll}0 & 1250 \\
0 & .1247\end{array}$ & $\begin{array}{lll}0 & 0450 \\
0 & 0.429 & 1\end{array}$ & $\begin{array}{ll}0 & 0035 \\
0 & 00063\end{array}$ & 1.291 & 0.687 & 0.170 \\
\hline
\end{tabular}

The most apparent results of the previous continued action of the dilute acid is seen in the effects upon the phosphoric acid, and more notably upon the iron. This action upon the iron we were persuaded of during the course of the "time experiments," which was seen, first in the coloration of the solution by the dissolved iron, and, as the fermentation proceeded, in the formation of an iron-colored scum on the insides of the bottles, and the disappearance of the color from the solution. The citric acid attacks the iron strongly, and the iron citrates, formed by the action of the acid on the soils, appear to be specially sensitive to the soil bateria-crenothrix polyspora, cladothrix dichotoma, leptothrix ochracet, and other bacteria which are known to act upon the compounds of iron in soils and waters.

We shall not discuss further at this time the results obtained by acting upon soils with considerable volumes of dilute solutions of citric acid. Those results have furnished data of value and extreme interest, giving us a further insight into the complex processes that operate in soils; but they have not led us to the actual information we are in search of. The conditions of our methorls were not such as must exist in Nature. The soils under treatment were still exposed to a constant excess of moistule, although the volume of solution applied was merely enough to immerse the soils in the bottles-200ec. of solution to 200 grams of soil. Early in the course of 
these "time experiments" we saw that the excess of water, in which the citric acid was dissolved, was going to produce consequences out of hamony with any possible processes operating in the field, and we commenced a further series of observations which were conducted under quite different conditions.

T'me Action of Acme a Difute Soldtions Applien in Volume Corresponding to the Amsorptife Power of timb Sorts.-In the following series of "time experiments," in the first place, the rolume of water that the soils could absorb was determined. That rolume known, enough citric acid was dissolved in it to make it exactly an onetenth per cent solution, and the solution was applied to known weights of the upland and lowland soils respectively, and as follows: 390 grams of water-free soil were put into beakers of 500ce. capacity. When putting in the soil, pieces of half-inch diameter glass tube were set in the midlle of the beakers, one end of the tube resting on the bottom, and the other end reaching up six inches above the top of the beaker, and the soil was filling into the beaker with these glass tubes standing in the middles. The purpose of these tubes was to secure a more uniform distribution of the solvent; which, if it were all applied at the surface, the action would be chiefly confined to the upper part of the soil in the beakers. Onehalf of the solvent was applied through the tubes, by which means the solution went to the bottom of the soil in the beakers and rose upwards by capillarity, and the other half was applied at the top, somewhat later, which descended by gravity to meet the rising volume, thus securing the most even distribution throughout the soil. The weight of each beaker was taken at the time of the first application, when exactly the volume of solution 
was added to saturate the soils. Every fourth day, the weights of the beaker's were retaken, the volume of water ascertained that had evaporated, and a rolume equal to that lost by evaporation was added to each beaker, and in this added water, enough acid was dissolved to bring the whole volume of water in each beaker up to the strength of an one-tenth per cent. solution again. This was done at intervals of four days, and continued for 120 days. Only a single series of soils in beakers was carried on, no analyses being made until the end of the period stated. In addition, however, to the use of an one-tenth per cent. solution of citric acid, parallel observations were made of the action of an one-tenth per cent. solution of asparagin, and upon the same upland and lowland soils that were used in the "time experiments" previously recorded. The amounts of solution, and of the crystallized citric acid and asparagin respectively, that were applied to the soils in beakers dming the period of 120 days we give as follows:

\begin{tabular}{|c|c|c|c|c|}
\hline \multirow[b]{2}{*}{ Acids. } & \multicolumn{2}{|c|}{ UPLAND SOTLS. } & \multicolumn{2}{|c|}{ LOWLAND SOILS. } \\
\hline & $\begin{array}{l}\text { Amount of } \\
\text { Solution. }\end{array}$ & Weight of Acid. & $\begin{array}{l}\text { Amount of } \\
\text { Solution. }\end{array}$ & Weight of Acid \\
\hline $\begin{array}{l}\text { Citrie Acid. } \\
\text { Asparagin. . }\end{array}$ & $\begin{array}{l}1027 \mathrm{cc} \\
1031 \mathrm{cc}\end{array}$ & $\begin{array}{ll}7.50 & \mathrm{grs} . \\
7.55 & \mathrm{grs} .\end{array}$ & $\begin{array}{l}912 \mathrm{cc} \\
916 \mathrm{ce}\end{array}$ & $\begin{array}{l}6.96 \text { grs. } \\
6.99 \text { grs. }\end{array}$ \\
\hline
\end{tabular}

The upland soils, having a greater absorptive power, and eraporating some 10 per cent. more moisture, also received somewhat more of each of the two acids.

As there was no excess of solution in these experiments our means of observing what had been the action of the respective solvents upon the soils during the period of time stated was by comparing the proportions of the 
elements found soluble in an one per cent. solution of citric acid in the natural soil, and in this same soil after the treatment with the solvents for the length of time stated. We shall give first the amounts of lime, potash, and phosphoric acid, as shown by the agricultural analyses, in the soils, which soils have been exchusively used in the former", and in the present series of "time experiments."

\begin{tabular}{|c|c|c|c|c|c|}
\hline Soil. & $\begin{array}{c}\text { Type } \\
\text { Samples. }\end{array}$ & $\begin{array}{c}\text { Suly- } \\
\text { Samples. }\end{array}$ & $\mathrm{CaO}$ & $\mathrm{K}_{2} \mathrm{O}$ & $\mathrm{P}_{2} \mathrm{O}_{5}$ \\
\hline $\begin{array}{l}\text { Upland ......... } \\
\text { Lowlaud .... }\end{array}$ & $\begin{array}{l}9 \\
9\end{array}$ & $\begin{array}{l}108 \\
108\end{array}$ & $\begin{array}{c}\text { Per cent. } \\
0.284 \\
0.389\end{array}$ & $\begin{array}{c}\text { Per cent. } \\
0.298 \\
0.389\end{array}$ & $\begin{array}{c}\text { Per cent. } \\
0 \quad 341 \\
0.296\end{array}$ \\
\hline
\end{tabular}

We now give the results of the action of the dilute solvents, covering the length of time stated.

A-gives the amounts of the elements soluble in one per cent. citric acid in the fine enth of the natural soils.

B-the amounts of the same elements soluble in the same soils after they had been acted upon by the onetenth solution of citric acid for 120 days.

C-the amounts of the same elements soluble in the same soils after they had been acted upon by one-tenth solution of asparayin for 120 days.

\begin{tabular}{|c|c|c|c|c|c|c|c|}
\hline Soils. & Class & $C a O$ & $\begin{array}{c}\text { Poumls } \\
\text { per Acre }\end{array}$ & $\mathrm{K}_{2} \mathrm{O}$ & $\begin{array}{l}\text { Pounds } \\
\text { per Acre }\end{array}$ & $\mathrm{P}_{2} \mathrm{O}_{5}$ & $\begin{array}{l}\text { Pounds } \\
\text { per Aere }\end{array}$ \\
\hline & & $\begin{array}{l}\text { Per } \\
\text { cent. }\end{array}$ & & $\begin{array}{c}\text { Per } \\
\text { cent. }\end{array}$ & & $\begin{array}{l}\text { Per } \\
\text { cent. }\end{array}$ & \\
\hline Uplands & A & 0.1380 & 4830 & 0.0220 & 770 & 0.0052 & 182 \\
\hline "6 & B & 01477 & 5169 & $0.027 t$ & 959 & $0.00 \pm 6$ & 161 \\
\hline " & $\mathrm{C}$ & 0.1437 & 5028 & $\begin{array}{lll}0 & 0293\end{array}$ & 1023 & 0.0066 & 231 \\
\hline Lowlands & A & 0.1450 & 5075 & 0.0450 & 1575 & 00060 & 210 \\
\hline 6 & B & 0.1545 & $5 t$ & 0.0397 & 138 & 00051 & 178 \\
\hline "6 & $\mathrm{C}$ & 0.1510 & 5285 & 0.0128 & 1498 & 0.0066 & 231 \\
\hline
\end{tabular}


These results were obtained by the action of the said solvents upon the "fine earth" of the upland and lowland soils. In the former series of "time experiments" the whole soil, and not the fine earth was used. 'This statement is necessary to explain why the one per cent. citric acid has, in this series, taken out a larger proportion of the elements than were dissolved out of the same soils, by the same acid solution, in the former series. The results thus also indicate to what extent the action of the solvents depends upon the state of fimeness of the soils.

Before discussing these results further, another series will be given showing the comparative action of one per cent., one-tenth, and one-fiftieth per cent. solutions respectively of citric acid upon a soil of a totally different type. The mode of application of the solvents was exactly the same as in the series last described, the volume of water absorbed by the soil controlling the volume of solution added and maintained, and the renewal of acid being made every fourth day. In this series 25 1bs. of soil were taken for each test. The soil was placed in galvanized iron buckets of 3 gallons capacity each. Before filling in the soil, pieces of iron tubes were set in the center of each bucket through which the solvent was to be partially applied, precisely the same as in the example of the beakers, and for the same purposes, viz., to secure a better distribution of the solvent throughout the mass of the soil. The results obtained with this series on a large scale are given as follow-

A (Table 1) gives the lime, potash, and phosphoric acid in the soil, as shown by the agricultural analysis, and the amounts of these elements soluble in water, and one per cent. solution of citric acid respectively, in the natural soil. 
B ('Table 2) shows the relative amounts of the elements soluble in water in the three quantities of soil after the action of the solvents of different strengths, at the end of 130 days.

C (Table 3) shows the relative amounts of the elements soluble in one per. cent. solution of citric acid at the end of the period of action of the several solvents.

\section{A.-('IABLE 1.)}

Agricultural Analysis

Soluble in Water

\begin{tabular}{|c|c|c|}
\hline $\mathrm{CaO}$ & $\mathbf{K}_{2} \mathrm{O}$ & $\mathrm{P}_{2} \mathrm{O}_{5}$ \\
\hline Per cent. & Per cent. & Per cent. \\
\hline 0.8610 & 0.5810 & 1.0500 \\
\hline 0.0038 & 0.0019 & 00011 \\
\hline $0.3+10$ & 00380 & 01270 \\
\hline $0.00 \pm 1$ & 0.0038 & 0.0013 \\
\hline 0.0045 & 0.0046 & 0.0010 \\
\hline 0.0092 & 0.0077 & 0.0006 \\
\hline 0.4342 & 0.0571 & 0.1498 \\
\hline 0.4544 & 0.0582 & 0.1408 \\
\hline 0.5056 & 0.0543 & 0.1482 \\
\hline
\end{tabular}

$$
\text { B.--(TABLE 2.) }
$$

Action of One-fiftieth per cent. Solution ... 0.0041 Action of One-tenth per cent Solution...... 0.0045 Action of One per cent. Solution..........

$$
\text { C.- (TABLE 3.) }
$$

Action of One-fiftieth per cent. Solution ..... 0.4342 Action of One-tenth per cent. Solution ...... 0.4544 Action of One per cent. Solution............

This soil was used on account of its ample contents of lime and potash, and the enormous amount of phosphoric acid, which, in distinction from Hawaiian soils, generally, is in a state of great solubility.

To understand more clearly what the action of the several strengths of solvent has been, and its relation to crop necessities, we shall arange the results in another form. 
LIME.

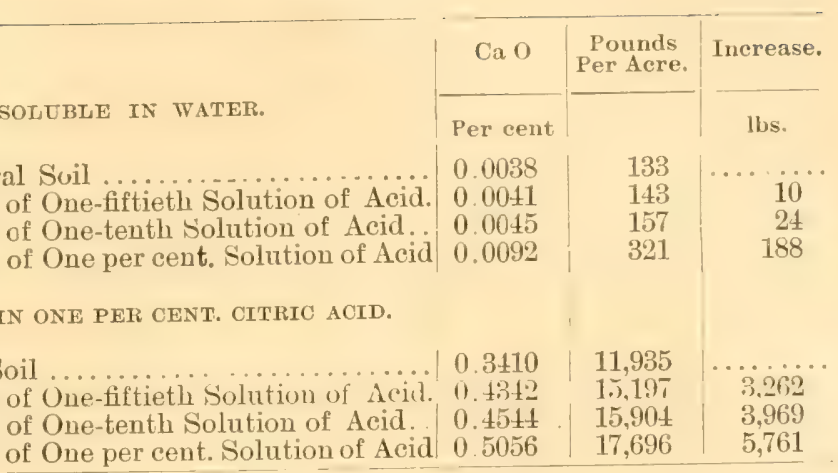

\section{POTASH.}

In the Natural Suil ................... Action After Action of One-tenth Solution of Acid.

After Action of One per cent. Solution of Acid

SOLUBLE IN ONE PER CENT. CITRIC ACID.

In Natural Soil

\begin{tabular}{c|c|c}
\hline$K_{2} O$ & $\begin{array}{c}\text { Pounds } \\
\text { Per Acre. }\end{array}$ & Increase.
\end{tabular}

SOLUBLE IN WATER.

$\left.\overline{\text { Per cent. }}\right|^{-} \quad$ lbs.

In the Natural Soil

() 0019

After Action of One-fiftieth Solution of Acid $\mid 0.0038$

After Action of One-tenth Solution of Acid. . 0.0046

After Action of One per cent. Solution of Acid

0.0077

SOLUBLE IN ONE PER CENT. CITRIC ACID.

In the Natural Soil

0.0380

After Action of One-fiftieth Solution of Acid. 00571

After Action of One-tenth Solution of Acid. 0.0582

After Action of One per cent. Solntion of Acid 0 (1) 0543

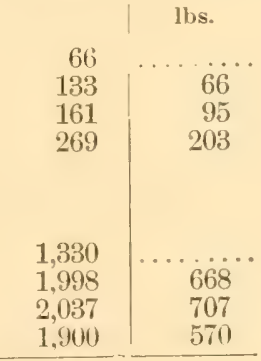

PHOSPHORIC ACID.

\begin{tabular}{|c|c|c|c|}
\hline & $\mathrm{P}_{2} \mathrm{O}_{5}$ & $\begin{array}{l}\text { Pounds } \\
\text { Per Acre. }\end{array}$ & Increase. \\
\hline SOLUBLE IN WATER. & Per cent. & & lbs. \\
\hline In the Natural Soil $\ldots \ldots \ldots \ldots \ldots \ldots \ldots$ & 0.0011 & 38 & \\
\hline After Action of One-fiftieth Solution of Acid. & 00013 & 45 & ( \\
\hline After Action of One-tenth Solution of Acid. & 0.0010 & 35 & loss 3 \\
\hline $\begin{array}{l}\text { After Action of One per cent. Solution of Acid } \\
\text { SOLUBLE IN ONE PER CENT. CITRIO ACID. }\end{array}$ & 0.0006 & 21 & loss 17 \\
\hline In the Natural Soil $\ldots \ldots \ldots \ldots \ldots \ldots$. & 0.1270 & 4,445 & \\
\hline After Action of One-fiftieth Solntion of Acid. & 0.1498 & 5,243 & 798 \\
\hline After Action of One-tenth Solntion of Acid. & 0.1408 & 4.928 & 483 \\
\hline After Action of One per cent. Solution of Acid & 0.1482 & $5.1 \times$ & 7.42 \\
\hline
\end{tabular}


We shall repeat that in all these analyses never less than 200 grams of soil were lswel, and that in the former series, with the upland and lowland soils in bealiers, :390 grams were taken. This explanation is repeated in oreler to show that the results to the fourth de.imal alde doubly as reliable where 200 grams are taken, as the results in the second decimal are, where one gram is taken for analysis.

The data furnished by the last series of experiments, where 25 lbs. of soil were taken for each test, are the most definite and instructive. It is seen that comparatively little change was wrought by the action of the solvents in the amounts of lime and potash soluble in water. That action added respectively, 10 lbs., 24 lbs., and $188 \mathrm{lbs}$. of lime soluble in water to the amount of water soluble lime in the natural soil; of potash, were added $66 \mathrm{lbs} ., 95 \mathrm{lbs}$, and $203 \mathrm{lbs}$. to the former water soluble amounts. If these increased proportions of watersoluble elements were the measure of the action of the solvents, covering four months, it would be moderate, and more in hamony with the probable atetion of natural processes; we see, however, that the amounts of lime and potash rendered soluble in one per cent. citric acid are chormons, even in complarison with larege proportions soluble in that solvent in the natural soil. There are features in the behaviour of the potash which attract special attention. It is seen that less potash is found soluble in one per cent. citric acid after the action for 130 days of the one per cent. solvent than where the one-fiftieth per cent. solvent was used. 'This behariour is also repeated in the beaker series of experiments with

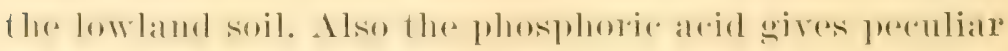
results of the same nature. In every example the soils 
acted upon for 130 days by the stronger solvents showed less phosphoric acid soluble in one per cent. citric acid after, than before the action. These peculiar results are bound up with the question of resorption, and they led to some observations bearing on the greater question"Are the constituents dissolved by acids actually carried out of the soil, or are they, and to what extent, reabsorbed from the solution?"

As a first test, a given rolume of a solution, which had been obtained by treating a soil with a dilute solution of citric acid, containing kuown amounts of given elements, was passed through a new quantity of the same soil, called A.

A second test consisted in passing another but a similar solution, which har been obtained by the action of a dilute citric acid solution upon the soil, through a totally different soil-B. The lime, potash, and phosphoric acid in soils $A$ and $B$, through which the solutions were passed, are first given:

\begin{tabular}{|c|c|c|c|}
\hline Soils. & $\mathrm{CaO}$ & $\mathrm{K}_{2} \mathrm{O}$ & $\mathrm{P}_{2} \mathrm{O}_{5}$ \\
\hline $\begin{array}{l}\mathrm{A} \\
\mathrm{B}\end{array} \ldots \ldots \ldots \ldots \ldots$ & $\begin{array}{c}\text { Per cent. } \\
0.861 \\
0.403\end{array}$ & $\begin{array}{c}\text { Per cent. } \\
0.591 \\
0.783\end{array}$ & $\begin{array}{r}\text { Per cent. } \\
1.050 \\
0.256\end{array}$ \\
\hline
\end{tabular}

The results of the tests are now given successively: FIRST TEST.

\begin{tabular}{l|c|c|c|c|c}
\hline Elements in the Solution. & $\mathrm{Ca} O$ & $\mathrm{~K}_{2} \mathrm{O}$ & $\mathrm{P}_{2} \mathrm{O}_{5}$ & $\mathrm{Fe}_{2} \mathrm{Al}_{2} \mathrm{O}_{6}$ & $\mathrm{Si}_{2}$ \\
\cline { 2 - 6 } & $\begin{array}{c}\text { Per } \\
\text { cent. }\end{array}$ & $\begin{array}{c}\text { Per } \\
\text { cent. }\end{array}$ & $\begin{array}{c}\text { Per } \\
\text { cent. }\end{array}$ & $\begin{array}{c}\text { Per } \\
\text { cent. }\end{array}$ & $\begin{array}{c}\text { Per } \\
\text { cent. }\end{array}$ \\
Before passing through. & 0391 & 0.078 & 0.178 & 0.539 & 0 \\
After passing through... & 0.432 & 0.148 & 0.050 & 0.647 & 0.152
\end{tabular}


SECONI 'THA'T'.

\begin{tabular}{|c|c|c|c|c|c|}
\hline \multirow[t]{2}{*}{ Elements in the Solution. } & $\mathrm{CaO}$ & $\mathrm{K}_{2} \mathrm{O}$ & $\mathrm{P}_{2} \mathrm{O}_{5}$ & $\left|\mathrm{Fe}_{2} \mathrm{Al}_{2} \mathrm{O}_{6}\right|$ & $\mathrm{Si} \mathrm{O}_{2}$ \\
\hline & $\begin{array}{l}\text { Per } \\
\text { cent. }\end{array}$ & $\begin{array}{l}\text { Per } \\
\text { cent. }\end{array}$ & $\begin{array}{l}\text { Per } \\
\text { cent. }\end{array}$ & $\begin{array}{l}\text { Per } \\
\text { cent. }\end{array}$ & $\begin{array}{l}\text { Per } \\
\text { cent. }\end{array}$ \\
\hline Before passing through. . & 0.340 & 0.038 & 0.127 & 0.663 & 0.199 \\
\hline After passing through... & 0.321 & 0.019 & 0.038 & $0.6 \pm 1$ & 0.194 \\
\hline
\end{tabular}

In the second test, the acidity of the solution before passing through was=11.2ec. alkali; after passing trough $=10.2 \mathrm{cc}$. alkali.

In the first test the result of passing the solution through the same soil was to increase its lime, to double its potash, and to reduce its phosphoric acid contents. This appears remarkable (although we bear in mind the basic nature of the soil); for it is seen that the soil took up more phosphoric acid of which it already possessed an enormons quantity, and gave up to the passing solution a double quantity of potash, although the potash in soil $A$ is only two-thirds of the quantity in soil $B$.

In the second test, it is seen that, despite the rery high potash content of soil B, that soil took one-half of the potash out of the solution on its passing through; also the samesoil, althomgh its content of phosphoride ald was only one-fourth as large as that of soil $\mathrm{A}$, did not absorb any phosphoric acid from the passing solution. These, and other similar observations have led us to note that there is not any necessary relation between the amount of an element already contained by a soil and the amount that the soil will absorb. It is indicated that the power to absort is controlled less by the quantity that the soil contains, and decidedly more by the chemical form in which it is contained, that has been hitherto molerstoorl. 'The behavior of acid and nentral soils in relation to ab- 
scrption caused us to think that the acid or neutral reaction of the solution would effect the absorptive power of the soil through which it was passed; and, consequently, that the power of soils in the field to hold back and prevent the loss of elements bought into solution by water may be partly controlled by their acid or neutral character. Observations bearing on this question were made upon a mixed soil, which was made up of equal quantities taken from 100 sub-samples. This mixed soil was treated with one per cent. citric acid for 24 hours, when the solution was separated from the soil by filtration. This solution thus obtained, and containing the elements dissolved, was used for the tests, which were made as follows-200 grams of the said "mixed soil" were put into a funnel, with a ground top and glass cover plate; a given rolume of the said solution was poured upon the soil in the funnel, and allowed to pass through slowly, this being controlled by a piece of rubber tube upon the stem of the funnel, on which was put a pinchcock. The solution was passed through at the rate of 30 drops per minute, and when run through, it was re-passed throngh, thus continuing for 72 homrs in each test. In explanation of the results to be given-

A-gives the elements in the solution, which was still acirl.

$B$ - gives the elements in the solution after been passed through a fresh quantity of soil.

$\mathrm{C}$-gives the elements in the solution, which was neutralized with carbonate of soda, before being passed through the fresh soil.

D-gives the elements in the solution which was passed throngh the original soil from which the solution was 
obtained, and at the same rate, and for the same length of time (72 hours) as in tests B and C.

\begin{tabular}{|c|c|c|c|c|c|c|}
\hline Solutions. & & $\mathrm{CaO}$ & $\mathrm{K}_{2} \mathrm{O}$ & $\mathrm{P}_{2} \mathrm{O}_{5}$ & $\mathrm{Fe}_{2} \mathrm{Al}_{2} \mathrm{O}_{6}$ & ${ }_{6} \mathrm{Si} \mathrm{O}_{2}$ \\
\hline & & $\begin{array}{l}\text { Per } \\
\text { cent }\end{array}$ & $\begin{array}{l}\text { Per } \\
\text { cent. }\end{array}$ & $\begin{array}{l}\text { Per } \\
\text { cent. }\end{array}$ & Per cent. & $\begin{array}{l}\text { Per } \\
\text { cent }\end{array}$ \\
\hline Original Solution .............. & A & 0.1387 & 0.0228 & 0.0052 & 21.0271 & 0.2010 \\
\hline 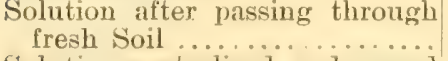 & B & & & 0.0028 & $\begin{array}{ll}3 & 0.8938\end{array}$ & 0.1040 \\
\hline $\begin{array}{l}\text { Solution neutralized, and passed } \\
\text { through fresh Soil .. }\end{array}$ & $\mathrm{C}$ & 0.0633 & 0.021 & 0.0031 & 0.6414 & 0.059 \\
\hline Solution after passing through & & & & & & \\
\hline the Original Soil. ............. & D & 0.1535 & 00403 & 0.0050 & 1.3130 & 0.2258 \\
\hline
\end{tabular}

Test D-shows that the result of continuing to pass the solution through the soil from which it har been obtained was merely to dissolve out more of the sereral elements, excepting phosphoric acid.

Test C-shows an emphatic absorption by the fresh soil of all elements, notably of the lime, silicic acid, and iron. This is in particular agreement with observations upon the action of dilute citric acid upon neutral soils in distinction from the action of the same solvent on acid soils.

Test B-shows that in the absence of the carbonic acid, furnished by the carbonate of soda, as in test $\mathrm{C}$, the lime and also the potash, continue to increase in the solution when it is passed through the fresh soil. But almost one-half of the silica and phosphoric acid are taken out of the solution by the fresh soil, with a notable amount of the iron and alumina bases.

Certain of our observations are in agreement with, and others are emphatically opposed to, the findings of distinguished chemists, from the researches of Way down to more recent date. This, howerer, is more to be expected than wondered at. The absorption experiments conducted by all other chemists were made with soils 
either of a moderately, or highly ariclic chander" whilst these investigations are with soils of an ultra basic nature and this fundamental difference in the soils must exercise a determining effect in their relation to solvents used in ascertaining the so-called availability of their constituents, and in their property of absorption.

The results that we have given, with other observations not recorded, indicate that, in the matter of $\mathrm{Ha}$ waiian soils, the action on the one hand, of solvents upon soils, and on the other hand, of soils upon solutions, is controlled by the following factors:

1. The basic, or non-acidic nature of the soils.

2. Their structural composition, or difference of chemical form in which the constituent elements are present.

3. The neutral or acid reaction of the soils, due to free organic acids derived from the decay of less or greater amounts of regetable matter, as foumb in upland and lowland soils.

4. As affecting absorption, the kind of acid in the solution, which will be shown at a later place.

5. The acid, neutral, or alkaline reaction of the solution containing the elements, and that is to be passed through, or brought in contact with the soils.

Our several laboratory modes of trying to estimate the plant food axailable in soils, which have caused us to traverse a very extensive ground of observation, have furnished knowledge of great value, and having a farreaching interest. The results, however, have not provided the precise information that we sought, but have inclicated that that information is not to be found along lines, and by methods, of pure artificial research, and that 
we must go out into Nature, and note the results of her processes in the field. Having done this, it may then be

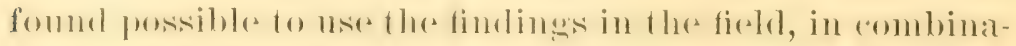
tion with aljusted methorls in the latboratory, to guide us more actually in dealing with questions that come up in everyday practice.

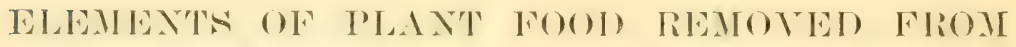 IIAT IIIN NOITA BY WITER I NDGTOPPIXC.}

In an early paragraph of this part of our investigations we endeavored to indicate the materials in soils which povide thesolvent agents which operate through nat ural processes in rendering the insoluble elements suitable for plant food. We drelt mpon the decay of regetable matter, and the acids that result from the decay, which, with water, carry on the work of food-preparation. WVe did not attempt, howerer, to follow the minute and complicated processes which Nature, with an unknown diversity of detail, may pursue in working out her ends. These may be infinitely intricate, or they may be more simple than we at present can grasp.

If we cannot follow her methods, we can judge of their results; and these are recorded, on a grand scale, in certain of the final processes by which her work is carried on and matured.

Emements Removen by Waters of Discharge.-In the curleavor to find a brief and comprohensive expression of the results of the enormous and manifold action of water, and its leaching power on soils, we are usually referred to the composition of sea water. So eminent an antholity as Ponfossol Ililgallol ars in this matter, and salys "the nsmal nature of the substateres so learled out 
is well illustrated in the salts of sea-water, which represent the generalized result of countless ages of this leaching process.". This statement is found in one of the most distinguished of his valuable publications- "IRelation of Soils to Climate."

The error of taking sea water as an indication of the relative proportions of elements leached from soils is suggested by the great variation in the composition of the salts found in the different seas. This variation is set forth by the great number of analyses that have been made of the waters of all seas, certain typical ones being given in the following tables:

COMPOSITION OF THE SALTS IN SEA WATERS.

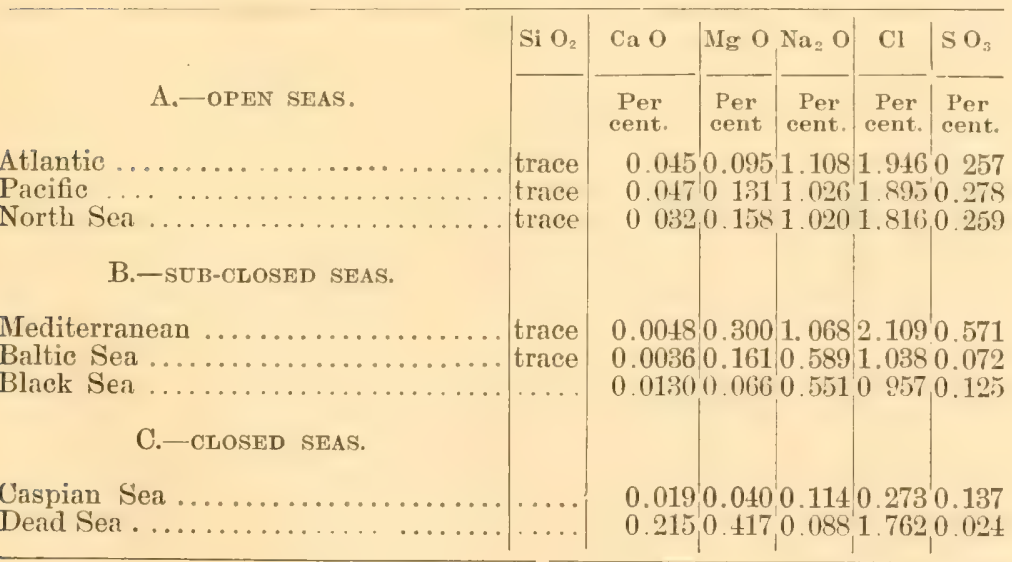

The composition of the waters of those several seas may be allowed to suggest the different composition of the rocks and soils which form the great water-sheds discharging into those seas. The suggestion must be taken with reserve, however, and before discussing it further we shall consider another argument showing 
why the composition of sea-water cannot represent the relative amounts of the elements pemoved from the land and carried into the ocean by water.

In the first part of these investigations we gave the composition of Hawaiian lavas, and also, in another place, the composition of the great mass of Hawaiian soils. For the present purpose we shall bring the analyses of the lavas and soils together. The analyses of the soils are absolute, and give the full composition of the mineral matter of the soils.

\begin{tabular}{|c|c|c|c|c|c|c|c|}
\hline Hawailan. & $\mathrm{Si} \mathrm{O}_{2}$ & $\mathrm{Al}_{2} \mathrm{O}_{3}$ & $\mathrm{Fe}_{2} \mathrm{O}_{3}$ & $\mathrm{CaO}$ & $\mathrm{MgO}$ & $\mathrm{Na}_{2} \mathrm{O}$ & $\mathbf{K}_{2} \mathrm{O}$ \\
\hline & $\begin{array}{c}\text { Per cent. } \\
+\tau 900\end{array}$ & $\begin{array}{l}\text { Per cent. } \\
\text { 1s } 230\end{array}$ & $\begin{array}{c}\text { Pex cent. } \\
13360\end{array}$ & $\begin{array}{c}\text { Per cent } \text {. } \\
8990\end{array}$ & $\begin{array}{c}\text { Per cent. } \\
60.50\end{array}$ & $\begin{array}{c}\text { Per cent } \\
2200\end{array}$ & Per cent. \\
\hline & 29813 & .27 .221 & $34 \quad 326$ & 0.928 & 1.407 & 1641 & 0.853 \\
\hline
\end{tabular}

This comparison shows that, in the passing orer of the laras into soils, there have been removed 18 tons, ont of every 48 tons, of silica; 8 tons out of every 9 tons, of lime; $4 \frac{1}{2}$ tons, out of every 6 tons, of magnesia; one-half of erery $1 \frac{1}{2}$ tons of potash; and only one-fourth of erery $2 \frac{1}{5}$ tons of sodium. We see then, that sodium, which constitutes only about 2 per cent. of the original lava, is remored in the least proportion of the elements specified. This behaviour of sodium is in keeping with all our other observations, and with what we know of the silicates of the metal in the arts and manufactures, which are conspicuous by their insoluble nature; and it in nowise conflicts with the further observation, that when sodium is once made soluble, it is remored from soil more rapidly than potash, for example, which is due to the different relations of the olements to the absorptive property of soil. 
In considering the disintegration of IIawaiian lavas, and the elements that are removed, we have to bear in mind their difference of composition as compared with other rock-formations that are in constant course of decay, and whose elements are being carried elsetwhere, and into the sea. We say "elsewhere," for the reason that, in the decomposition of original lavas, elements are separated out, which go to the making of deposits, in large mass, at lower altitudes, whose elements do not go direct to the sea, ret they are not accounted for in grineral soils. These results of disintegration were considered in the first part of this work.

It is hardly a matter, however, that is difficult to explain why so much lime, magnesia, potash and silica, and so little soda, have been carried into the sea, and yet sodium compounds compose such a vast proportion of the salts in most ocean waters. Lime, and also magnesia with mineral acids, constitute the material with which those representatives of the animal kinglom liring in the waters of the seas have built up their structures of bone and shell, and which bones and shells have gone towards the laying down of those massive formations of limestone which are found upon so grand a scale in the structure of the earth. The lime of those limestones was at one time bound up in the composition of rocks and lavas. On their disintegration, It was carried into the seas; and from the seas, it was gathered up by the myriad denizens of the ocean and stored away in the masses in which it is now found. The millions of tons of coral reef which encompass these islands, and which our analyses show to contain over 96 per cent. of lime carbonate, and one or more per cent. carbonate of magnesia, form a most elaborate instance of what becomes of the lime. 


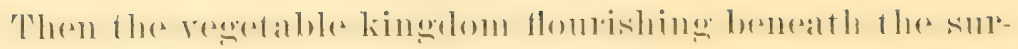
face of the seas, - its orders draw upon the nitrogen, phosphoric acid, and still more upon the silica, and also the potash, which have gone from the decaying rocks and soils into the sea. These indications of the behaviour of the potash have a rery particular bearing upon the views hitherto set forth by agricultural chemists. The sum of these things, therefore, causes us to look upon the salts found in the waters of seas not as the collective mass of material which was carried out from the land, but rather as the residue of matter remaining after the animals and plants living and multiplying in the seas, by their selective action, have taken ont of the waters the missing elements, each animal and plant after its manner and needs.

Having concluded that the composition of sea water does not furnish any means of estimating the relative proportions in which the elements composing rocks and soils are remored and carried into the sea, we undertook an examination of the actual waters of discharge which are learing the lands at this time. To ascertain the composition of those water's at the present time will amply serve our purpose; yet it must be borne in mind that the composition of the waters that are discharging to-day will not indicate the relative amounts of the elements that have been bolne to the sea during previous periods of time. When original rocks and lavas commence disintegration, in the first stages of the process, the more soluble elements are remored first, and in great excess. As the decomposition proceeds, and little of the most soluble is left to be removed, the less soluble elements must come more into prominence in the composition of the discharging streams. Consequently not only the nature of the rocks, but also their age and state of decay, have a 
bearing upon the composition of the material that is being removed from them by water.

Before treating of the waters discharging from the Hawaiian Islands, we shall consider such data as we possess bearing upon the character of the waters discharging from lands in older countries. Unfortunately we are not sure (although it is probable), that the data represent waters in normal discharge, or whether they may not be from streams at a time when the volume of discharge was either less or greater than normal, which differences can affect the composition of the water. Again, few analyses of water have been made from the standpoint of our present purpose. The reasons for water analysis generally, are hygienic, and not geological; and the examinations are seldom full. Judging from data that are available, more attention has been given to water analysis in England than in other of the older countries. We therefore bring together in average such analyses as bear upon our purpose. This average embraces the composition of streams and springs in the southern counties of England-Middlesex, Kent, etc., and is as follows:

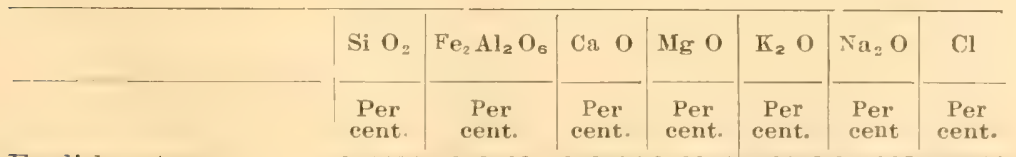

English waters.

0 0008 $00002 \quad 0.00596000040001020 .0007$ (: 0009

Attention is first called by the analysis to the amount of silica in the discharging waters. This is very noteworthy, since in sea waters merely a trace is recorded. It is seen that the lime being carried to the sea is fourteen times greater than the soda, the great excess of lime be- 
ing dne to the huge formations of limestone found in somblem Englate, and thromsh which the drainage has passed. Even the potash is one-third of the quantity of the soda in those waste waters, whilst in sea water, according to Regnault, there are only 2 parts of potash to 100 parts of soda. We shall not use more time in discussing the features of composition of the discharge waters in other countries. The examples used are only given for their value in comparison, and to illustrate the troth that the composition of the mineral matter in waste waters is dependent upon the nature and age of the rockformations over and through which the waters are flowing. 'The composition of the waters discharging frum the four larger islands of the Hawaiian group will now be considered, and in geological relation to the main purpose of these investigations.

As soon as it appeared to the writer that a knowledge of the composition of the mineral matter in the waters dischalroing from the four ohief islands into the sea would be absolutely necessary to a solution of matters that form an integral part of our main investigation, a course was adopted by which waters were selected, and samples taken, that should represent the water-sheds of all the great momntains that are dischaldeing theil waste waters through the soils and lava formations of each district of the four islands-Hawaii, Mani, Oahu and Kanai. 'The areas of these islands are, in the order of the names giren, respectively 4,210, 760,600 and 590 square miles, or an

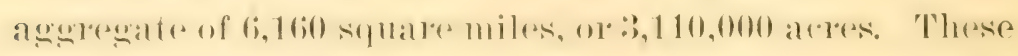
areas indicate that the project was not onlo feasible, but that the conditions, such as the existence of the aggregate area in sub-areas of each island, specially 
contribute to make possible the sampling of the bulk of waste waters with convenience and exactness.

In the course of the repeated visits to the islands, and the slow, methodic tours of study and observation, through each district of every island, the writer had opportunities to note the location, number, and size of the rivers, streams, and many of the springs of discharge, from several of which the cubic-sccond volume has been determined. By means of these opportunities the locations rere selected for taking samples, which were as follows:

HATAIr-Region of Kohala; from the Kohala watershed discharging in the district of Halawa and Niulii.

Region of Hamakua; replesenting the main watershed of Mauna Kea, discharging at Panilo and Kukaiau.

Region of Hilo; the Wailuku river, being the main discharge from the slopes of Mauna Loa.

Madr-The great watershed of East Mani, discharging by way of the slopes of the greatest crater mountain on the earth-Haleakala-samples taken from the Paia and spreckelsville streams. Also from the watershed of West Maui, the samples being taken at Wriluku.

O.nut-From the streams discharging at Homolulu and Pearl Harbor.

Kadar.-From the watershed on the north side of the island in the district of Kilauea. From the region of Waialeale, and mountains above Mahaulapu, discharging at Koloa, and from the Waimea river, which stream gathers up the discharges from countless springs and streams that descend from the mountain ranges of the large region of Waimea.

Our analyses of individual waters indicate very small rariations in their composition, exceptius samples talien 
from locations that are affected by the sea, in which not only the sodium increases, but the proportions of the other bases have become changed.

The grand arerage, which sets forth the composition of the mineral matter found in the waters discharging by way of the watersheds, and from all the areas specified, is given in the following data of analysis, molerneath which we reprodnce the composition of the English waters for the instruction afforded by the comparison:

\begin{tabular}{|c|c|c|c|c|c|c|c|c|c|}
\hline Waters. & $\mathrm{Si} \mathrm{O}_{2}$ & $\mathrm{Fe}_{2} \mathrm{Al}_{2} \mathrm{O}_{6}$ & $\mathrm{CaO}$ & $\mathrm{MgO}$ & $\mathrm{K}_{2} \mathrm{O}$ & $\mathrm{Na}_{2} \mathrm{O}$ & $\mathrm{Cl}$ & $\mathrm{SO}_{3}$ & $\mathrm{P}_{2} \mathrm{O}_{5}$ \\
\hline & $\begin{array}{l}\text { Per } \\
\text { cent. }\end{array}$ & $\begin{array}{l}\text { Per } \\
\text { cent }\end{array}$ & $\begin{array}{c}\text { Per } \\
\text { cent. }\end{array}$ & $\begin{array}{l}\text { Per } \\
\text { cent }\end{array}$ & $\begin{array}{l}\text { Per } \\
\text { cent. }\end{array}$ & $\begin{array}{l}\text { Per } \\
\text { cent. }\end{array}$ & $\begin{array}{c}\text { Per } \\
\text { cent }\end{array}$ & $\begin{array}{c}\text { Per } \\
\text { cent. }\end{array}$ & $\begin{array}{l}\text { Per } \\
\text { cent. }\end{array}$ \\
\hline Hawailim & (1) $11112: 3$ & 0.0005 & 0.0413 & 0.00133 & 00001.5 & 0.00333 & 0.0040 & 0.00011 & 0.0001 \\
\hline Euglish & $0.000(1)$ & 0.010002 & 0.00996 & 1). 0001.1 & $0.06(1) 2$ & 0.00007 & 0.0009 & & \\
\hline
\end{tabular}

Passing on from the great interest and instruction that are afforded by the comparison of the analyses, the nature of which we have discussed in previous paragraphs, we come into the possession of data which furnish the most reliable means that we can use in estimating the relative amounts of the elements of plant food that are removed from the soil by the processes of Nature, and of bringing the results of the laboratory for comparison, by the side of truths obtained from the field, which facts and conclusious found in the ways of Nature must be a standard in judgment. Before proceeding with the comparison, we shall try to supplement the conclusions furnished by the study of the waters of discharge with other data strictly furnished by the field.

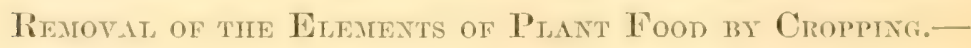
In speaking of the removal of plan food materials by "cropping," we have very carefully to distinguish be- 
tween the total amount removed by acts of cultivation, by rain falling on cultivated land, and by crops, all of which make up the total action of "cropping," and the small amounts that are taken away by the crops alone. We have data showing that of $7000 \mathrm{lbs}$. of lime removed from given lands per acre by cropping, not quite 1000 lbs. of that amount were carried off by the actual crops. Also that not more than one-half of the potash removed was actually taken away in the harvested growths. These data also show that any system of judging of the depletion, or of restoring, the fertility of soils, that is based upon a mere calculation of the amounts of the elements that are carried away from the land in crops is devoid of any approach to the actual facts in the matter:

In the course of the past three years we have taken samples of soil from all districts on each of the four larger islands. As already explained, those samples were taken personally by the writer, or strictly in localities and fields selected by him, and according to his instructions. Those soils have undergone the common agricultural analysis, making altogether analyses of 94 type soils, and 1328 sub-samples. Of this number, 64 type soils, and 768 sub-samples, were examined in such a way as to throw special light upon the present relative compositions of "virgin" and "cropped" soils. As it is said in the report on soils for 1895, "In taking samples of cropped lands, in every possible case, a sample of virgin soil was taken, corresponding in all requisite conditions to that of the cropped soil, and a comparison is made of the two." The 64 type soils represent both up. lands and lowlands. For our present purpose we are able to use and consider only the upland soils, since the 
question before us is the "amounts of materials that have been lemored from the solis by ropping," and this question only applies to the uplands, from which the elements have been washed away by the rains, and in some cases carried to the lowlands, and not direct into the sea, which is shown by some of the lowland cropped soils being ridere in given elements than the virein soils of the same localities. For this purpose there are some 34 type soils, including 408 sub-samples of soil. These

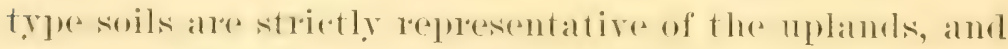
were taken from most districts on each island. We have analyses of about 140 more sub-samples of cropped upland soils, which correspond in results with the others, but as there are not rirgin samples to compare with these, they are excluded from the comparison. In the following table we bring together in average the results of the 34 types, and 408 sub-samples:

UPLANDS.

\begin{tabular}{|c|c|c|c|}
\hline Elements. & Virgin. & Cropped. & Loss. \\
\hline Lime & Per cent. & Per cent. & Per cent. \\
\hline 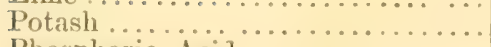 & 0.324 & 0.270 & 16.60 \\
\hline Phosphoric Acid................. & 0.248 & 0.243 & 2.02 \\
\hline
\end{tabular}

The results of the analyses, which raried between more and less than the grand average, show that $40 \%$ of the lime, $16.6 \%$ of the potash, and $2 \%$ of the phosphoric acid have been removed from the cultivated upland soils by cropping.

The amount of phosphoric acid removed may appear less than the crops would have taken off. 'That is not so. Upon the uplands, the extreme average production of 
sugar has been $2 \frac{1}{2}$ tons per acre, which at 8 tons of cane to 1 ton of sugar, means 20 tons, or $40,000 \mathrm{lbs}$. of cane per acre. The average ash content of the cane, as shown by numerous analeses, is $0.5 \%$, of which total ash according to Stenhouse and others, $6.8 \%$ is phosphoric acid. 'Theu, according to these analises, 40,000 lbs. of cance would remove 13.5 lbs. of phosphoric acid; consequently 10 crops, of 20 tons per acre each, would carry off 135 lbs. of phosphoric acid. In these calculations the cane tops, which contain three or four times the amount of ash that the manufactured cane does, are excluded, because these are left on the land and the mineral matter is returned to the soil, the phosphoric acid being partly washed out by the rains with other elements, but more largely refixed by the iron in the soil. It is indicated that during the growth of 10 crops on the uplands, not more than $120 \mathrm{lbs}$ of phosphoric acid were removed by the crops; jet 200 lbs. were actually removed.

We have only the chemical analyses for the support of this statement so far as the actual amounts of the elements are in question that have been removed. But the number of analyses upon which the statement is based, although large and representative, may be too few upon which to base an estimate of the actual weights and proportions of the sereral elements that have been lost since the cropping began. Although we have no further check upon the statement of the actual amounts that have been removed, we can ascertain whether the proportions of lime, potash and phosphoric acid, whirh the soil analyses say have been lost, bear a relation to each other which gives to the analytical statement the stamp of probability. For this purpose we make use of the analyses of the "waters of discharge," which set forth 
the actual relative proportions in which those elements are daily and homly leaving the land and going into the ocean. 'The average of the analyses of the waters leaving the Hawaiian Islands gives the following relative proportions.

\section{HAWAIIAN WATERS.}

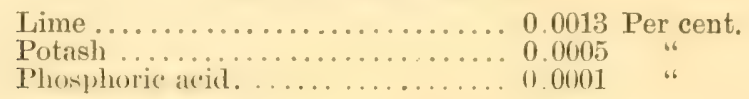

We shall now bring these elements, in the relative proportions in which they are being actually carried away in the waters, into comparision with the same elements in the proportions in which they are being removed by cropping from the upland soils. As a standard in the comparison we select the element lime, and for the reason that lime is being removed by both the waters and arepping in vastly greater proportion than the other elements. The amount of lime that has been removed from the soils by eropping is $40.2 \%$; therefore we take this as the standard, applying it also to express the lime contrent in the waters of discharge, and bringing the potash and phosphoric acid into relation with it. The results of this comparison appear as follows-

ELEMENTS REMOVED FROM ELEMENTS REMOTED FROM THE SOIL IN WATERS

\begin{tabular}{c|c|c|c|c|c|c}
\hline Lime. & Potash. & $\begin{array}{c}\text { Phosphoric } \\
\text { Acid. }\end{array}$ & Lime. & Potash. & $\begin{array}{c}\text { Phosphoric } \\
\text { Acid. }\end{array}$ \\
\cline { 1 - 2 } Per cent. & Per cent & Per cent. & Per cent. & Per cent. & Per cent. \\
40.2 & 15.1 & 2.80 & 40.2 & 16.6 & 2.02 \\
\hline
\end{tabular}


These results are nothing short of remarkable! The comparison shows us that the elements lime, potash and phosphoric, that are being lost to the land, have been, and are being removed by the "waters of discharge," and by "cropping," in the same relative proportions. 'This, however, is what was to expected after the previous observation, viz. - that the bulk of the soil materials that is lost by cropping is not carried off by the crops, but is washed away by the heary rains from the cultivated lands. Now these heavy rains, which fall chiefly upon the uplands, removing the soluble soil materials, comprise also the actual waters of discharge. But we hare found in the results of this comparison an ample verification of the conclusions reached by our soil examinations. The aualyses of typical soils from all districts of the four chief islands state that given amounts of lime, potash and phosphoric acid have been lost to the upland soils by the action of cropping in given relative proportions; and the analysis of the discharge waters shows the removal of those elements in almost the same proportions that they are being lost. We have thus a double check in estimating the loss of materials from the soil that results from the processes of Nature in the field, and a two-fold standard for judging of the value of any observations made in the laboratory.

By the aid of these standards we may proceed to examine into the meaning and value of the labolatory results that have already been obtained. For this purpose we leave outside the results, already recorded, that were obtained by observing the action of different strengths of citric and other acids upon soils for rarring leugths of time. It was seen that factors, such as resorption, operate in those experiments, whose occult action we 
cannot minutely follow, and the results of which, so far, we are unable to estimate. Consequently we shall simply note the action of different solvents upon the same soil for the same length of time.

The soils used in conducting the further series of observations that we shall now record were the samples of the "cropped" upland soils which were used for analyses in estimating the action of ropping upon the mplands. By using these soils we shall make the results strictly comparable with the stambard furnished by the lesults found in examining the waters of discharge, and the action of cropping. The actual sample used was made up by putting together equal weights of the type soils already described. This was done to save time, the areratging of the soils before analysis being matle, insteal of the averaging of the results of the individual analyses of each soil at the other end. In each test 200 grams of soil were taken, and acted upon by an one per cent. solution of atch solvent for 24 homs, all conditions being strictly the same. 'The solvents used were citric, tartaric, oxalic and acetic acids; and asparagin and aspartic acid. The action of other amido acids was to be observed, but the mannfaturing rhemists in rermany replied that the ropuiled solyents andel not be sent until specially made, so the observations were curtailed.

The purpose of this series is to note the action of each solvent, and afterwards to bring the results into com-

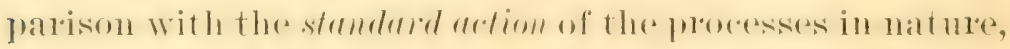
as indicated by the results of "cropping," and the examination of the "discharge waters." 
ELEMENTS DISSOLVED BY THE ACTION OF ONE PER CENT SOLUTIONS OF THE FOLLOIING ACIDS IN 24 HOURS.

\begin{tabular}{|c|c|c|c|c|c|}
\hline Acids. & $\mathrm{CaO}$ & $\mathrm{K}_{2} \mathrm{O}$ & $\mathrm{P}_{2} \mathrm{O}_{5}$ & $\mid \begin{array}{llll}\mathrm{Fe}_{2} & \mathrm{Al}_{2} & \mathrm{O}_{\mathbf{8}}\end{array}$ & $\mathrm{Si} \mathrm{O} \mathrm{O}_{2}$ \\
\hline & Per cent & Per cent. & Per cent. & Per cent. & Per cent. \\
\hline Aspartic & 0.1065 & 0.0489 & 0.0054 & 0.0450 & 0.1060 \\
\hline Asparagin. & 0.0078 & 0.0117 & 0.0015 & 0.0050 & 0.1740 \\
\hline Citric .... & 0.1110 & 0.0260 & 0.0037 & 0.6630 & 0.1990 \\
\hline Acetic . & 0.1000 & 0.0240 & 0.00013 & 0.0060 & 0.0740 \\
\hline Tartaric.. & 0.1180 & 0.0240 & 0.0054 & 0.1880 & 0.1970 \\
\hline Oxalic..$\ldots \ldots \ldots \ldots \ldots$ & 0.0170 & 0.0226 & 0.0106 & $0.5 \pm 30$ & 0.2330 \\
\hline
\end{tabular}

These data set forth the relative actions of the respective solvents upon the elements of the same soil. To present the meaning of the data in a more clear and significant light, we arange them in another form. In doing so, we also bring them into comparison with the standard of results from the action of processes in Nature, in order to determine and note the relative proportions of the elements that are dissolved by the respective solvents, as compared with the proportions of the same elements removed by cropping and found in the waste waters.

RELATION OF THE PROPORTIONS OF THE ELENENTS SOLUBLE IN THE ACIDS TO THE PROPORTIONS RENOVED BY "CROPPING", AND BY THE "WATERS OF DISCHARGE."

\begin{tabular}{|c|c|c|c|c|c|}
\hline Removed By & $\mathrm{CaO}$ & $\mathbf{K}_{2} \mathrm{O}$ & $\mathrm{P}_{2} \mathrm{O}_{5}$ & $\mathrm{Fe}_{2} \mathrm{Al}_{2} \mathrm{O}_{8}$ & $\mathrm{Si} \mathrm{O}_{2}$ \\
\hline & Per cent: & Per cent. & Per cent. & Per cent. & Per cent \\
\hline "Cropping" $\quad . . . . .$. & 40.2 & 16.6 & 2.02 & & \\
\hline "Discharge Waters". & 40.2 & 15.1 & 280 & 15.00 & 71.5 \\
\hline Aspartic Acid....... & 40.2 & 18.1 & 2.02 & 16.90 & 40.0 \\
\hline Asparagin .... & 40.2 & 59.8 & 7.70 & 62.40 & 892.0 \\
\hline Citric Acid........... & 40.2 & 8.7 & 1.08 & 238.90 & 71.8 \\
\hline Acetic Acid ............ & 40.2 & 9.6 & 0.01 & 24.00 & 29.6 \\
\hline Tartaric Acid ........... & 40.2 & 8.1 & 1.80 & 63.70 & 66.6 \\
\hline Oxalic Acid....... & 40.2 & 53.1 & 24.90 & 1276.40 & $5+8.2$ \\
\hline
\end{tabular}

This table of results, showing the action of the given solvents as compared with the results of the processes 
in the field, points to conclusions of the greatest interest and moment in the study of soils, and in relation to the measure of arailability of the more important elements of plant food. The results bestow a most demonstrative apporat upon our hypothesis explatined in the earlier paragraphs of this part of the work, viz-that "the simple carbon acids, and likewise the amido acids, must exereise a chief function in the processes in Nature whereby the more insoluble constituents of the soil are prepared for the use of plants." In the above table it is seen that aspartic arid al'ts upon and dissolves the ronstituent elements of the soil in almost the exact relative proportions that those elements are removed by "cropping," and by the "waters of discharge." Asparagin, beiny a body having basic as well as acid properties, is not comparable with the acids. Althongh an amid, it belongs to the rass distinguished as comstructice amides, rather than a product of destructive processes, like other well-known amides that result from the decay of regetable organisms. The action of asparagin in dissolving potash has been markedly apparent throughout all our observations on that body. It is suggested that the mode of that action is displacement, the amidogen gronp ( $\left.\mathrm{NH}_{2}\right)$ taking the place of the soil bases.

The artion of citric acid requires particular notice beeanse of the dominant position given to that solvent in all previous considerations on the availability of plant food constituents in soils. The action of this acid mpon the lime, potash, and phosphorie acid is not only very far removed from the apparent action of natural processes, but its action upon the iron and alumina, esperially upon the iron, indicates that a general solvent action is exereised which is radically different to that which 
proceeds in the soils in place. The data showing the action of the other acids are laden with instruction and suggestiveness; yet we shall not give more space now to their discussion.

Having considered the relative proportions of the elements dissolred by different acids, and found that, in its action mon the Hawaiian soils that we have been examining, aspartic acid dissolves the phosphoric acid, potash, lime, and other bases, almost in the exact proportions that these elements are found in the discharge waters, and in which they are removed by cropping, we shall proceed to the final purpose of these investigations, and try to establish a mode of assaying the actual amounts of the lime, potash, and phosphoric acid that are available, and to give a more special sense to the term "available," we shall state available for the immediate crop of cane. To attempt this we must, most ericlently, leave the laboratory, and go out again into the field.

In the course of our repeated visits to plantations on all the islands, and with a view to the present purpose, we have endeavored to ascertain an average of the number of pears that the uplands have been under cultivation and cropping. This is very difficult to establish for the reason that, in the several districts, and even in the same district, the period varies extremely. There are uplands that have been cultirated for more than thirty years, and others less than fire years; in fact to-day new lands are being broken up and brought under crop. The areas, however, which we have more specially considered, and from which the upland samples of soil for analysis were taken, represent periods of cultiration that range between ten and thirty years. We believe that the average period must be very near to twenty years, since we are 
persuaded that it is more than fifteen years yet less than twenty-five years. It is about sixty years since sugar was first grown for sale upon the IIawaiian Islands. During the years previous to 1880 , when the sugar produced was 30,000 tons, as compared with 250,000 tons to-day, but litthe of the uplauds of to-day were under cultivation; ret some of the lower parts of these mplands in the drier districts were cropped, on account of the greater rainfall on these lands than on the levels near to the sea. For these rasons, and similar ones, we have been led to place the average length of time that the uplands have been under cultivation and cropping since thes were broken up, and more or less continuously, at twenty years. During those twenty years ten crops of cane have probably been grown. On some lauds more than ten crops may have been grown, on other lands they have certainly been less than ten; and, as an average, the extreme of production furnished by the uplands has been ten crops of cane.

Taking the length of time that the uplauds have been under cultivation and cropping, and the bulk of production at the estimates giren, then our agricultural analyses of the mpland soils shou thut under the action of tuent!y years of cropping and cultivation, and during the time of production of ten crops of cane, $40.2 \%$ of lime; $16.6 \%$ of potash, and $2.02 \%$ of phosphoric arid hase been actually removed from the land.

As a result of the action of an one per cont. solution of aspurtie arid upon the upland sorils for a period of 2!' hours

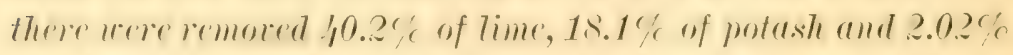
of phosphoric acid; whirhe amounts of materials are almost cxactly equal to the amounts of the same materials removed 
from the same soils by twenty years of cropping, and during the production of ten crops of cane.

By means of the data and conclusions set forth, and as a nearest approach to the solution of the main inquiry in this part of our investigations, we have to state that an one per cent solution of aspartic acid takes out of Hawaiian soils in 24 hours the same amounts of lime, potash and phosphoric acid that are removed during the production of ten crops of cane. Therefore one-tenth of those amounts may be talicn as the proportions of lime, potush and phosphoric acid that are acailable for the immediate crop of cane.

In concluding this part of the work, we specially recall attention to the conditions that have made our mode of inrestigation possible. In large, continental countries it is not possible to compass the processes operating in Nature, and to estimate the final results of those processes, as we have been able to do, in determining the actual materials of plant food that have been removed from the soil, during a giren length of time, by the acts of cropping, and in guaging the relative amounts of the elements that are being carried away from the land by the waters discharging into the sea. These islands however, are so relatively small, and all other conditions so conducive to the purpose, that our plan has been made practicable.

It is not necessary to dwell upon the labor that such a mode of investigation has involved, but it is in place to repeat our remarks upon the absolute necessity of studying the processes of Nature, and the practical questions and problems of agriculture, less exclusively in the laboratory, and more broadly and minutely in the field. The matter's that we have been trying to unfold are altogether questions of the field, and the functions of the 
laboratory ale subordinate and complementary to observations made ontrloor's. Soils must be taken where the conditions of their origin are understood, and all the data of enviromment carefully reorderl. Then the laboratory may exercise its office, and reveal what cannot be detected by the eye, and state what is, and what has been. Ibut the laboratory results, as these investigations have shown, have no claim on acceptance or authority unless they are shown to be in agreement with the results of the processes operating in the field.

One practical effect of our investigations and their results will be a notable change in the laboratory morle of assaying the fertility of soils for ererylay uses. The common "agricultural analyses" will be largely laid aside. "Absolute analyses" will be mate where problems are met with, such as have been recorded in the course of this work. In estimating the present state of fertility and for on guidance in fertilization of the immediate cropl, a reading will be talien of the soil, moler the action of the solvent that has been found to come the nearest to Nature in its results. 


\section{SUMMARY.}

The main features and conclusions developed in the foregoing pages we bring together briefly in the following paragraphs:

The soils of these islands are derived from volcanic lavas. Amongst Hawaiian lavas are those which have been discharged from craters, flowing and cooling into locks having the composition of normal basalts. Others, originally of the same composition, have undergone such alteration that they nom compose masses having a ladically different chemical composition and color appearance. This alteration took place at the time of ejection, and under the action of chemical causes, and previous to the later action of secondary causes of rock disintegration, such as "weathering," which has apparenty been the only agent of decomposition of certain of the normal lavas.

The study of the different kinds of lavas, and of the soils derived from them, has led to the division of the soils into types which are set forth as follows:

\section{A-GEOLOGICAL CLASSIFICATION.}

1. DARr RED SoILs.-Soils formed by the simple weathering of normal lavas, in climatic conditions of great heat and dryness. 
2. Yeliow and Ligmit Red Sotr.s.-Soils derived from lavas that mulerwent gereat alteration, moler the action of steam and sulphurous vapors, at the time of, or after emission from the craters.

3. Sedmentary Sorms.-Soils derived from the decomposition of lavis at higher altitures, and removal and deposition by rainfall at lower levels.

In addition to the classification based on geological differences in the lavas, the soils have been further "onsidered in rlasses dietated by the results of relimatic ronditions, and as follows:

\section{B-CLTMATTC CLASSIFICATION.}

1. Uptand Sorts.-Soils formed under lower temperatures and greater rainfall, and distinguished by a large content of organic matter and nitrogen, and by a low content of the elements of plant food in an available state; these elements having been removed by rainfall.

2. Lowland Soms.-Soils formed under higher temperature and smaller rainfall, and characterized by a lower content of organic matter and nitrogen, and by a higher content of the elements of plant food in a state of immediate availability, which is due in part to the receipt of some soluble ronstituents from the upper lands, and to a smaller rainfall orer the lower levels.

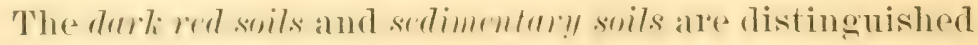
by a low or light red soils, which is set forth by the following table, including the mean of three years: 


\begin{tabular}{|c|c|c|}
\hline Types of Soil. & $\begin{array}{l}\text { Approximate } \\
\text { No. of Aeres }\end{array}$ & $\begin{array}{l}\text { Yield of Sugar } \\
\text { Per Acre. }\end{array}$ \\
\hline 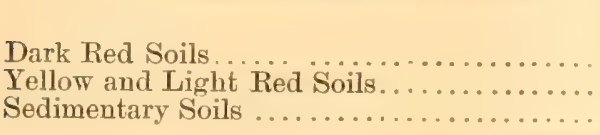 & $\begin{array}{l}30,000 \\
32,000 \\
20,000\end{array}$ & $\begin{array}{c}\text { Pounds. } \\
10,411 \\
6,291 \\
10,301\end{array}$ \\
\hline
\end{tabular}

The yellow and light red soils, which grow the least cane, produce the best quality of juice.

A comparison of American rocks with Hanaiian lavas, and of the soils respectively derived from them, have shown that the soils of these islands are totally different in type from the soils of the Uniter States, which is set forth by the great differences in physical properties and chemical composition. Relatively speaking, the soils of these islands are in their youth; and the soils of the United States and of Europe in a state of old age.

A comparison of the specific gravities of Hawaiian soils and lavas with the specific gravity of the general surface of the crust of the earth, and of the earth as a body, indicates that the lavas originate at a comparativeIy small depth below the surface, and thus mar not bear any necessary relation with the interior depths and conditions of the globe.

A very extensive series of investigations conducted for the purpose of ascertaining the state of availability of the elements of plant food in the upland and lowland soils has furnished data that completely confirm all previous statements on this matter. These inrestigations moreorer, have led to the establishing of a mode of estimating the elements in the soil that are readr for use, and of determining what must be furnished to meet the demands of the immediate crop. The basis of this mode of assaying the present fertility rests upon an actual knowledge 
of the elements of plant fool that are being remover by "cropping," and which are also being carried away and lost in the "discharge waters" that are leaving the land and flowing into the sea. We thus have found a rational foundation upon which to base a system of fertilization that recognizes the differences, and considers the needs, of individual soils.

Ourjoresent and futureconsiderations are beingand will continue to be giren to the relations of crops to the soils. A knowledge of the soil is an essential in laying the plans of such a study. But more than a knowlerlge of the soil is required, since we have to deal with the physiological relations of the plant to its environment, as well as with the soil. 







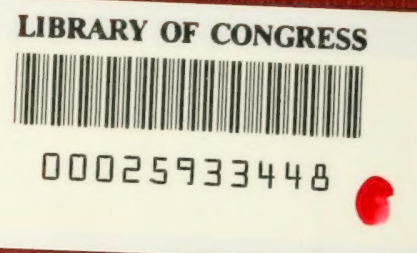

